Aus der Klinik für Allgemein-, Viszeral- und Kinderchirurgie

(Prof. Dr. med. B. M. Ghadimi)

Im Zentrum Chirurgie

der Medizinischen Fakultät der Universität Göttingen

\title{
Einfluss von microRNAs auf die Sensibilität von kolorektalen Tumorzellen gegenüber einer 5-FU- basierten Radiochemotherapie
}

\author{
INAUGURAL-DISSERTATION \\ zur Erlangung des Doktorgrades \\ der Medizinischen Fakultät \\ der Georg-August Universität zu Göttingen
}

vorgelegt von

Robert Hans-Joachim Templin

aus

Wilhelmshaven

Göttingen 2018 
Dekan:

Referent/in:

Ko- Referent/in:

Drittreferent/in:

Datum der mündlichen Prüfung:
Prof. Dr. rer. nat. H. K. Kroemer

Prof. Dr. med. J. Gaedcke 
Hiermit erkläre ich, die Dissertation mit dem Titel „Einfluss von microRNAs auf die Sensibilität von kolorektalen Tumorzellen gegenüber einer 5-FU-basierten Radiochemotherapie" eigenständig angefertigt und keine anderen als die von mir angegebenen Quellen und Hilfsmittel verwendet habe.

Göttingen, den 
I. Abkürzungsverzeichnis...............................................................II

II. Abbildungsverzeichnis..........................................................................

III. Tabellenverzeichnis.............................................................................

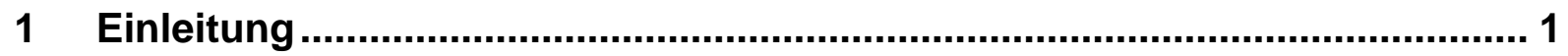

1.1 Epidemiologie und Ätiologie kolorektaler Karzinome .................................. 2

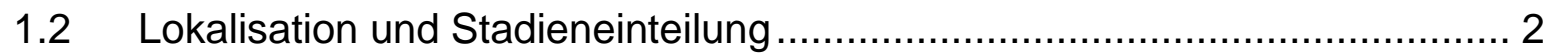

1.3 Adenom-Dysplasie-Karzinom-Sequenz ............................................... 6

1.4 Klinische Problematik der adjuvanten und neoadjuvaten

Radiochemotherapie beim Rektumkarzinom ................................................ 7

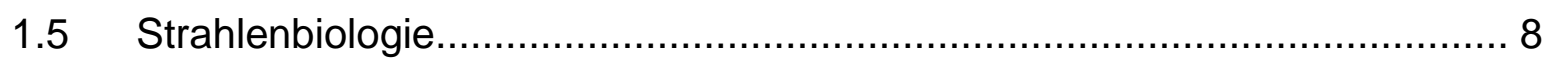

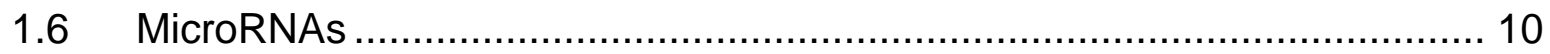

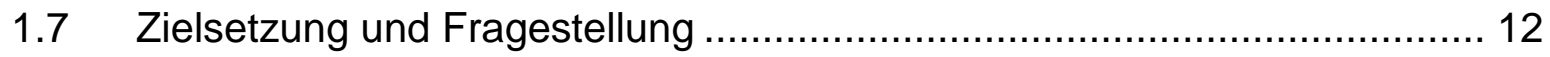

2 Material und Methoden ........................................................................... 15

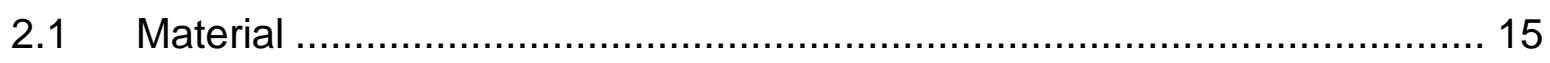

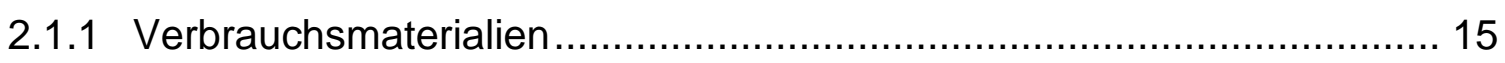

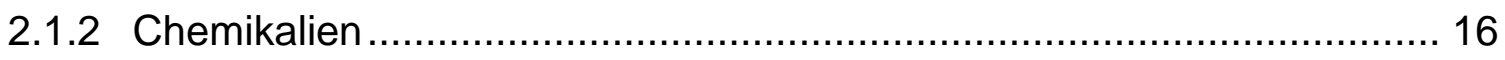

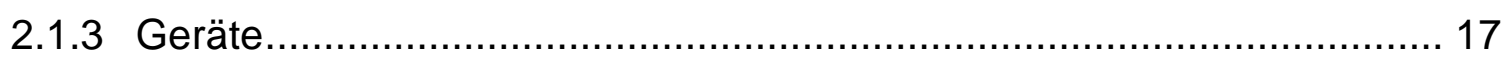

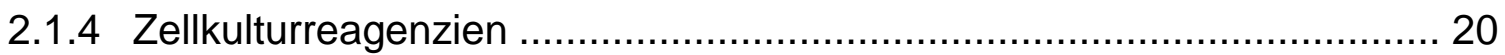

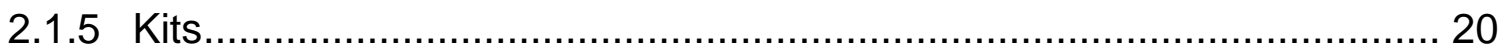

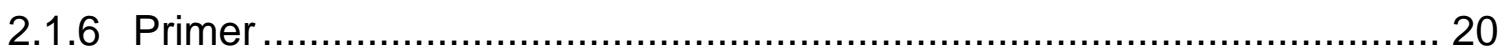

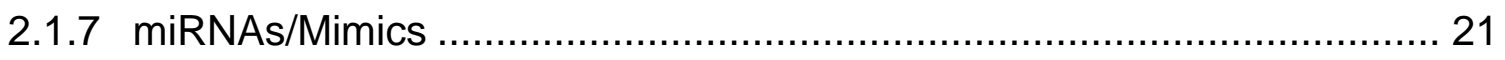

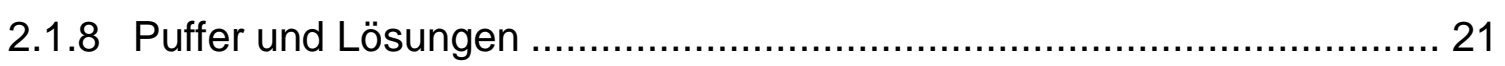

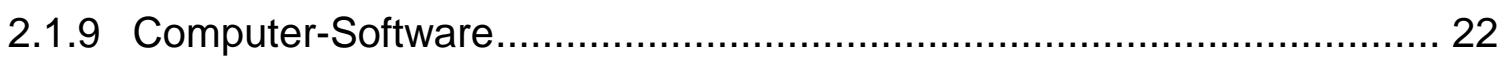

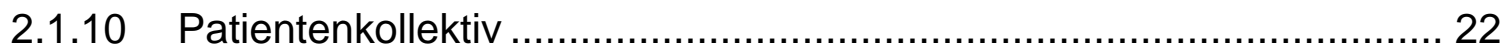

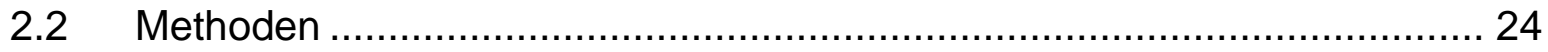

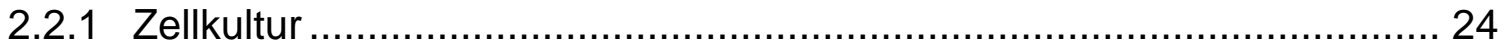

2.2.2 Stabile Transfektion von miRNAs durch Elektroporation ....................... 27

2.2.3 Colony-Forming-Unit-Culture-Assay (CFU-Assay)/ Zellbestrahlung ....... 28

2.2.4 Zellpräparation und RNA-Isolation................................................... 30

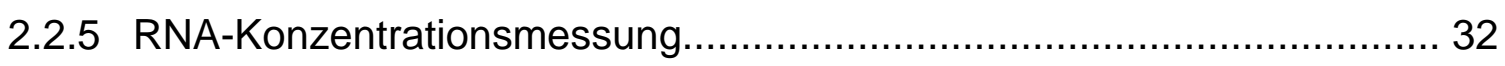

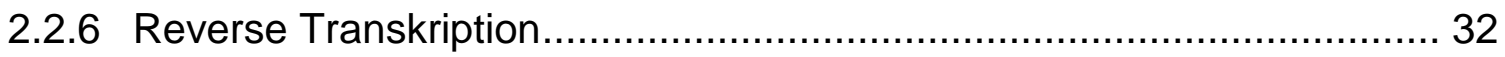

2.2.7 Semiquantitative Real-Time-PCR (qRT-PCR) .................................. 33

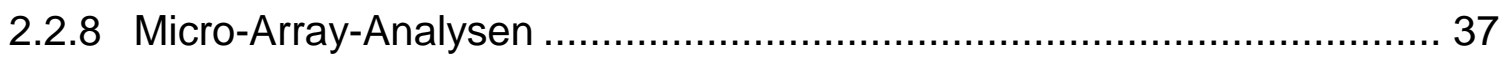




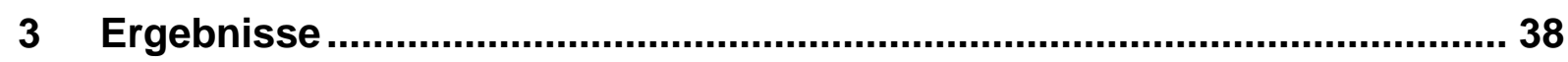

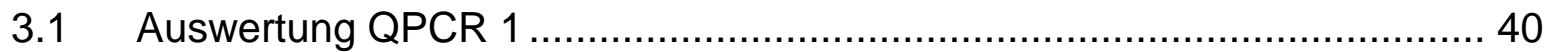

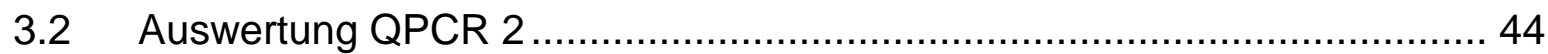

3.3 Auswertung Koloniebildungstest ..................................................... 50

3.4 Vergleich der Ergebnisse mit den klinisch-pathologischen Patientendaten 52

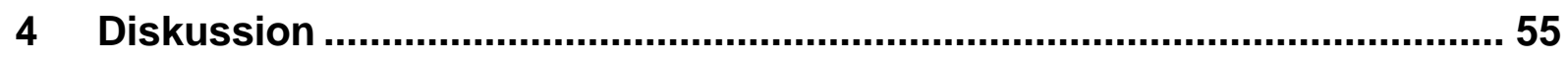

4.1 Rolle der untersuchten microRNAs beim Rektumkarzinom und anderen

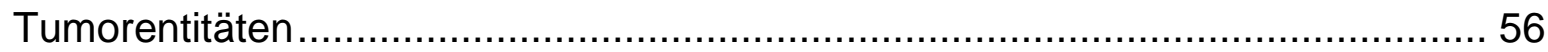

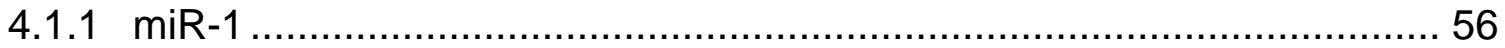

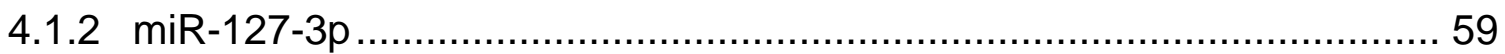

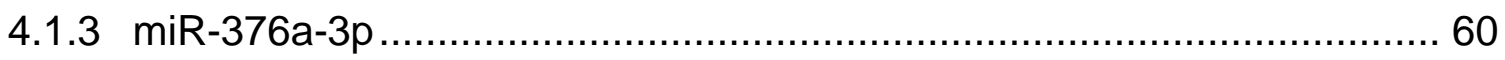

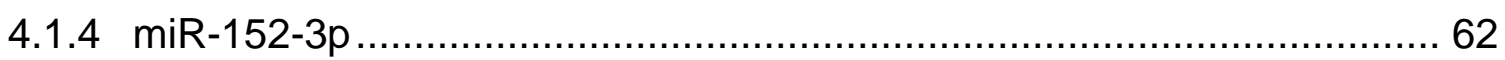

4.2 Vergleich der Ergebnisse mit klinisch-pathologischen Patientendaten und

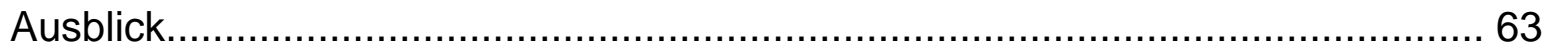

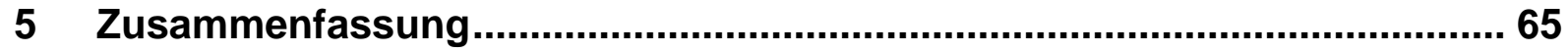

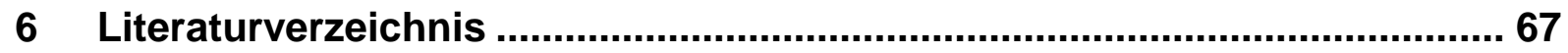

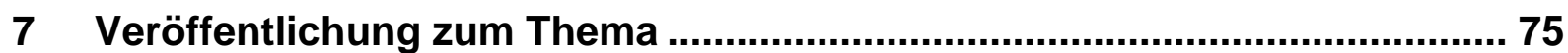




\section{Abkürzungsverzeichnis}

APC

Aqua dest.

ATCC

BSA

cDNA

CEA

CFU

CRC

Ct-Wert

$\mathrm{Da} / \mathrm{kDa}$

DCC

DNA/DNS

DNase

DTT

EDTA

EGFR

Fab

FBS

Fc-Fragment

Gy

KRAS

LK

M

MRT

PBS adenomatous polyposis coli

Aqua destillata

American Type Culture

Collection

bovines Serumalbumin

complementary DNA

Carcinoembryonales Antigen

Colony forming unit

colorectal carcinoma

Cycle-Threshold-Wert (auch:

Cq-Wert)

Dalton/Kilodalton

deleted in colon cancer

Deoxyribonucleic acid/

Deoxyribonukleinsäure

Desoxyribonuklease

Dithiotreitol

Ethylendiamin-tetraacetat

Epidermal Growth Factor

Receptor

antigen-binding fragment

fetal-bovines Serum

crystallisable fragment

Gray

Kirsten Rat Sarcoma

Lymphknoten

Einheit der molekularen

Masse

Magnetresonanztomographie phosphate-buffered saline 
PCR

Präop.

rcf

RCT

RKI

RNA

RNase

rpm

RPMI-Medium

RT

SEM

Taq

TBS

TBST

TNM-Stadium

cTNM

pTNM

TRG

Tris

TZ

UICC
Polymerase Chain Reaction

Präoperativ

relative centrifugal force

Radiochemotherapie

Robert Koch Institut

Ribonucleic acid

Ribonuklease

rotation per minute

Roswell Park Memorial

Institute Medium

Radiotherapie

standard error of the mean/

Standardfehler des

Mittelwertes

Thermus aquaticus

Tris-buffered saline

Tris-buffered saline plus

Tween

( $\mathrm{T}=$ Tumorgröße, $\mathrm{N}=$ LK-

Status, $M=$ Metastasen)

klinisches/bildgebendes

TNM-Stadium (auch uTNM)

pathologisches TNM-

Stadium

Tumorregressionsgrad

Hydroxymethylamino-

methan

Tumorzellen

Union internationale contre

le cancer

5-Fluorouracil 


\section{Abbildungsverzeichnis}

Abbildung 1: Lokalisation des kolorektalen Karzinoms ….......................... 3

Abbildung 2: Schematisch zusammengefasste Darstellung der Adenom-

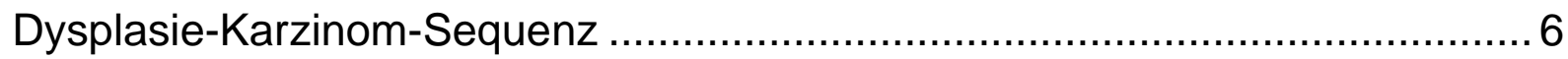

Abbildung 3: Strahlenwirkung und die resultierenden DNS-Schäden .......... 9

Abbildung 4: Strahlenempfindlichkeit während des Zellzyklus...................10

Abbildung 5: Schematische Darstellung der microRNA-Synthese ............... 12

Abbildung 6: Mögliche Reaktion der Tumorzellen auf RCT ...................... 13

Abbildung 7: Auflistung der verwendeten Primer der Firma Qiagen $\AA^{\circ} . \ldots \ldots . . .21$

Abbildung 8: Auflistung der verwendeten Mimics .................................... 21

Abbildung 9: Besetzung der 6-Well-Plates für CFU-Assay .......................28

Abbildung 10: Schematische Darstellung des Versuchsablaufs ...................29

Abbildung 11: Entparaffinieren mittels Xylol und Ethanol..............................30

Abbildung 12: Beispiel Pipettierschema QPCR 1 ..................................... 36

Abbildung 13: Beispiel Pipettierschema QPCR 2 .................................... 37

Abbildung 14: Schematischer Ablauf der Experimente …..............................39

Abbildung 15: QPCR 1, $\triangle$ Cq miR-1, -152-3p, -376a-3p und -127-3p .......... 41

Abbildung 16: QPCR 1, $\triangle$ Cq miR-548c-3p, $-431,-1913$ und $-570 \ldots \ldots \ldots \ldots . . . .42$

Abbildung 17: QPCR 1, $\Delta$ Cq miR-3663-5p und -4282 ............................. 43

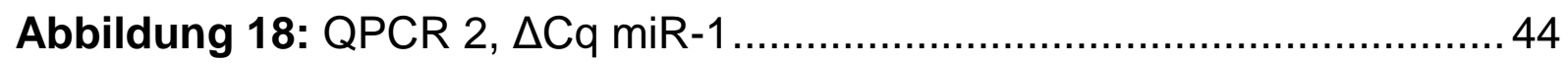

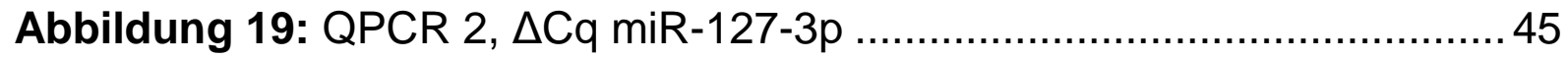

Abbildung 20: QPCR 2, $\triangle$ Cq miR-152-3p ............................................ 45

Abbildung 21: QPCR 2, $\triangle$ Cq miR-376a-3p …........................................... 46

Abbildung 22: Legende für Abbildung 19 bis 22 .................................... 46

Abbildung 23: Zusammenfassung QPCR 1 und QPCR 2 miR-1 ................ 47

Abbildung 24: Zusammenfassung QPCR 1 und QPCR 2 miR-127-3p ......... 47

Abbildung 25: Zusammenfassung QPCR 1 und QPCR 2 miR-152-3p ........ 48

Abbildung 26: Zusammenfassung QPCR 1 und QPCR 2 miR-376a-3p ....... 48

Abbildung 27: Koloniebildungstest mit Bestrahlung ohne 5-FU …................51 
Abbildung 28: Koloniebildungstest mit Bestrahlung mit 5-FU 51

Abbildung 29: Target miR-1 nach Filter klinische Daten 53

Abbildung 30: $\triangle \mathrm{T}$ - und $\Delta \mathrm{N}$-Status 54

Abbildung 31: TRG in Prozent 54

\section{Tabellenverzeichnis}

Tabelle 1: TNM-Klassifikation des kolorektalen Karzinoms.......................... 5

Tabelle 2: Stadiengruppierung, UICC 2010 .......................................... 5

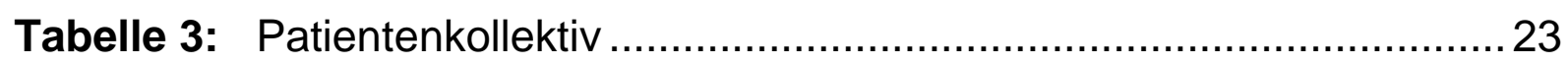

Tabelle 4: Wachstumsvoraussetzungen der verwendeten Zelllinie.............. 24

Tabelle 5: Volumina für Medienwechsel und Subkultivierung ..................... 25

Tabelle 6: Zellen pro Well in Abhängigkeit von der Strahlendosis ............... 29

Tabelle 7: Bestandteile des Mastermix aus dem RT-II-Kit@ (Qiagen) ........... 33

Tabelle 8: Temperaturprogramm des Bio-Rad CFX384-Termocyclers ........ 35

Tabelle 9: Komponenten und Volumina für qRT-PCR .................................. 35

Tabelle 10: Gesamtzusammenfassung QPCR 1 und QPCR 2 .................... 49

Tabelle 11: Relative Resistenzzunahme (RT) ….....................................50

Tabelle 12: Relative Resistenzzunahme (RCT) ......................................50 


\section{Einleitung}

Die neoadjuvante Radiochemotherapie gehört heutzutage zur Standardtherapie des lokal-fortgeschrittenen Rektumkarzinoms im mittleren und unteren Drittel. Das Ansprechen auf diese Therapie variiert jedoch interindividuell stark: Es reicht vom sehr gutem Ansprechen (complete response), bei dem der Tumor unter der Vortherapie komplett zurückgeht, bis hin zu einem sehr schlechten Ansprechen (non-response), bei dem der Tumor in Extremfällen unter der Therapie sogar wächst. Die zugrundeliegenden Mechanismen, welche die Sensibilität bzw. Resistenz der Tumorzellen gegenüber der neoadjuvanten Radiochemotherapie bedingen, sind bis heute nicht geklärt. MicroRNAs (miRNAs) sind kurze nicht-kodierende RNAAbschnitte, die die Translation bestimmter Gene inhibieren und somit eine große Rolle in der Genexpression spielen. Der Einfluss von miRNAs auf die Radiochemosensibilität von Rektumkarzinomzellen ist Gegenstand der vorliegenden Arbeit. 


\subsection{Epidemiologie und Ätiologie kolorektaler Karzinome}

Die Inzidenz kolorektaler Karzinome ist in Deutschland seit 1980 kontinuierlich gestiegen. 2012 lag die geschätzte Zahl der Neuerkrankungen erstmals bei über 70.000. Obwohl die Sterberate in den letzten Jahren leicht zurückgegangen ist, sind kolorektale Karzinome geschlechterunabhängig die zweithäufigste krebsbedingte Sterbeursache in Deutschland. Mit fortschreitendem Lebensalter steigt das Erkrankungsrisiko stetig an. Über die Hälfte der Erkrankten ist zum Diagnosezeitpunkt älter als 70 Jahre (RKI/GEKID 2015).

In etwa 5 - $10 \%$ der Fälle liegt eine erbliche Ursache der Erkrankung vor. Als häufigste Formen seien an dieser Stelle die familiäre adenomatöse Polyposis als obligate Präkanzerose (FAP, 1\% aller kolorektalen Karzinome) und das hereditäre, nichtpolypöse Kolonkarzinom-Syndrom (HNPCC/Lynch-Syndrom, $5 \%$ der kolorektalen Karzinome) genannt (Fuchs et al. 2014).

Weitere gesicherte Risikofaktoren sind Kolonpolypen, Alter, männliches Geschlecht, Rauchen, Adipositas, fetthaltige und ballaststoffarme Kost, Diabetes mellitus, chronisch entzündliche Darmerkrankungen, Schistosomiasis, eine positive Familienanamnese und der übermäßige Konsum von Alkohol und rotem Fleisch (Schmiegel et al. 2010). Neben Risikofaktoren sind jedoch auch protektive Faktoren bekannt. Hier sei exemplarisch als bekanntestes Beispiel die regelmäßige Einnahme von Acetylsalicylsäure ab einer täglichen Dosis von 75 mg genannt (Rothwell et al. 2010).

\subsection{Lokalisation und Stadieneinteilung}

Das Kolon wird unterteilt in Zökum, Colon ascendens, Colon transversum, Colon descendens, Colon sigmoideum und Rektum (siehe Abbildung 1).

Etwa ein Drittel aller kolorektalen Karzinome befinden sich im Rektum bzw. im Bereich des rektosigmoidalen Überganges, $25 \%$ betreffen das Sigmoid und jeweils etwa $20 \%$ verteilen sich auf den Bereich von Coecum bis Colon ascendens und das übrige Kolon (siehe Abbildung 1). 


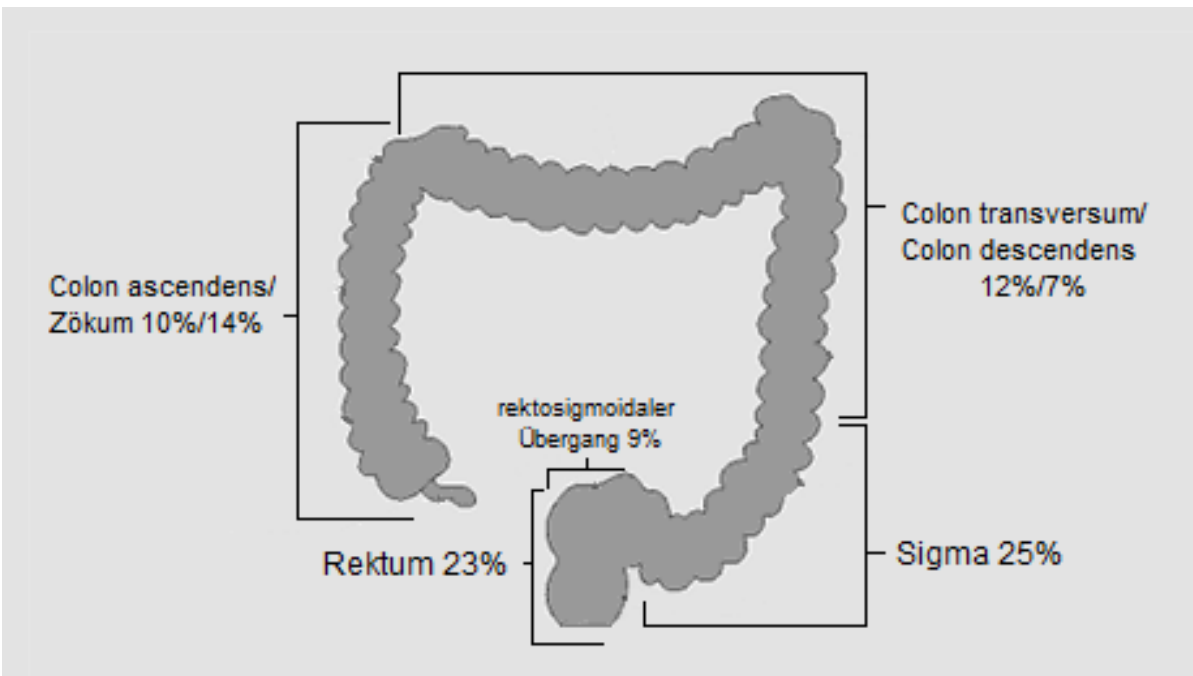

Abbildung 1: Lokalisation des kolorektalen Karzinoms und ihre relative Verteilung im Dickdarm (Schmoll et al. 2012)

Das kolorektale Karzinom ist histopathologisch in etwa $90 \%$ der Fälle ein Adenokarzinom. Die übrigen $10 \%$ fallen auf deutlich seltenere Formen wie beispielsweise Siegelringzellkarzinome oder muzinöse Adenokarzinome.

Das Rektum nimmt nicht nur aufgrund der prozentual häufigen Beteiligung eine besondere Rolle im Formenkreis der kolorektalen Karzinome ein. Die anatomische Lage im kleinen Becken und hiermit einhergehend die teils divergente Blutversorgung zum restlichen Kolon sowie der venöse und lymphogene Abfluss verleihen den hier auftretenden Karzinomen eine Sonderstellung.

Es liegen unterschiedliche Definitionen zur Angabe einer Grenze zwischen Kolon und Rektum vor. Auch die intraoperative Beurteilung anhand des Vorhandenseins einer Taenia oder der peritonealen Umschlagsfalte ist individuell unterschiedlich und beispielsweise von Alter oder Geschlecht abhängig. Eine präoperative Messung der Tumorhöhe mit dem flexiblen Endoskop ist unzuverlässig. Daher erfolgt im Allgemeinen die Höhenangabe mit dem starren Rektoskop. Hier dient die Anokutanlinie als distaler Messpunkt.

Nach dem internationalen Dokumentationssystem gelten als Rektumkarzinome jene Tumoren, deren aboraler Rand bei der Messung mit dem 
starren Rektoskop $16 \mathrm{~cm}$ oder weniger von der Anokutanlinie entfernt ist. Weiterhin werden die Rektumkarzinome entsprechend ihrem Abstand von der Anokutanlinie in Karzinome des oberen $(12-16 \mathrm{~cm})$, mittleren $(6-<12 \mathrm{~cm})$ und des unteren Rektumdrittels $(<6 \mathrm{~cm}$ ) untergliedert (AWMF-Leitlinie Kolorektales Karzinom 2017).

Zur vollständigen Ausbreitungsdiagnostik (Staging) gehören zudem nach Möglichkeit die Durchführung einer rektalen Endosonographie, einer vollständigen Koloskopie, eines MR-Becken, einer Röntgenuntersuchung des Thorax in zwei Ebenen und einer Abdomensonographie. Bei Unklarheiten hinsichtlich distanter Tumorherdsetzungen in der Leber oder der Lunge wird im Bedarfsfall die Bildgebung mittels Computertomographie ergänzt. Ebenso kann bei Kontraindikation zur Durchführung einer Magnetresonanztomographie (beispielsweise Vorhandensein von MR-inkompatiblen Metallen im Körper), zur lokalen Ausbreitungsdiagnostik ergänzend eine Computertomographie veranlasst werden.

Nach Abschluss der Umfelddiagnostik wird ein klinisches Tumorstadium erhoben.

Es wird nach der TNM-Klassifikation ( $T$ = Infiltrationstiefe des Primärtumors, $N$ = regionäre Lymphknotenmetastasierung, $\mathrm{M}=$ Fernmetastasierung, siehe Tab.1) der Union Internationale Contre le Cancer (UICC) in verschiedene Stadien eingeteilt (Wittekind und Meyer 2010, siehe Tab.2). Nach dieser Einteilung richtet sich die stadiengerechte Therapie gemäß der S3-Leitlinie der deutschen Krebsgesellschaft (Schmiegel et al. 2010). 


\begin{tabular}{|l|l|}
\hline TIS & Carcinoma in situ: intraepithelial oder Infiltration der Lamina propria \\
T1 & Submukosa \\
T2 & Muscularis propria \\
T3 & Subserosa, nicht peritonealisiertes perikolisches/perirektales Gewebe \\
T4a & Viszerales Peritoneum \\
T4b & Andere Organe oder Strukturen \\
\hline N0 & Keine regionäre Lymphknotenmetastase (LK) \\
N1a & 1 LK \\
N1b & $2-3$ LK \\
N1c & Tumorknötchen [=Satellit(en)] im Fettgewebe der Subserosa oder \\
& perikolischen/rektalen Fettgewebe ohne regionäre LK \\
N2a & $4-6$ LK \\
N2b & $\geq 7$ LK \\
\hline M0 & Keine Fernmetastasen \\
M1a & Fernmetastasen in 1 Organ (vor allem Leber, Lunge) \\
M1b & Fernmetastasen in mehr als 1 Organ oder im Peritoneum \\
\hline
\end{tabular}

Tabelle 1: TNM-Klassifikation des kolorektalen Karzinoms, UICC 2010 (Wittekind und Meyer 2010)

\begin{tabular}{|l|l|l|l|}
\hline \multicolumn{1}{|c|}{ UICC - Stadium } & \multicolumn{3}{c|}{ TNM - System } \\
\hline Stadium 0 & Tis & N0 & M0 \\
\hline Stadium I & T1, T2 & N0 & M0 \\
\hline Stadium IIA & T3 & N0 & M0 \\
\hline Stadium IIB & T4a & N0 & M0 \\
\hline Stadium IIC & T4b & N0 & M0 \\
\hline Stadium III & Jedes T & N1, N2 & M0 \\
\hline Stadium IIIA & T1, T2 & N1a & M0 \\
\hline Stadium IIIB & T1 & N2a & M0 \\
& T3, T4a & N1 & M0 \\
\hline Stadium IIIC & T2, T3 & N2a & M0 \\
& T1, T2 & N2b & M0 \\
\hline Stadium IVA & T4a & N2a & M0 \\
\hline Stadium IVB & T3, T4b & N2b & M0 \\
\hline
\end{tabular}

Tabelle 2: Stadiengruppierung, UICC 2010 (Wittekind und Meyer 2010) 


\subsection{Adenom-Dysplasie-Karzinom-Sequenz}

In den letzten Jahrzehnten hat das molekularbiologische Wissen über die Entstehung des Darmkrebses dank der intensiven Forschung maßgeblich zugenommen. Für die Entwicklung eines bösartigen Tumors im Darm bedarf es mehrerer genetischer Veränderungen. Das berühmteste Modell zur Beschreibung der Entwicklung von bösartigen Tumoren aus gutartigen Vorstufen (Polypen) ist die Adenom-Karzinom-Sequenz nach Fearon und Vogelstein. Fearon und Vogelstein beschreiben in ihrem TumorprogressionsModell die Entwicklung vom Normalepithel über das Adenom zum Karzinom. Die Progression bis zur Entstehung eines Karzinoms ist ein polygenetischer Prozess, welcher unter anderem die Mutation des APC-Gens beinhaltet. Wenn eine kritische Anzahl genetischer Veränderungen erreicht ist, kommt es zur malignen Transformation (siehe Abb.2). Das heißt, zuvor noch kontrolliertes Wachstumsverhalten schlägt in unkontrolliertes malignes Wachstum um. Bei den genetischen Veränderungen kann es sich sowohl um die Aktivierung von Onkogenen (z. B. K-RAS) als auch um die Inaktivierung von Tumorsuppressor-Genen handeln (beispielsweise p53 und DCC). Etwa $90 \%$ solcher intraepithelialen Neoplasien treten in Form von Adenomen auf (Fearon und Vogelstein 1990).

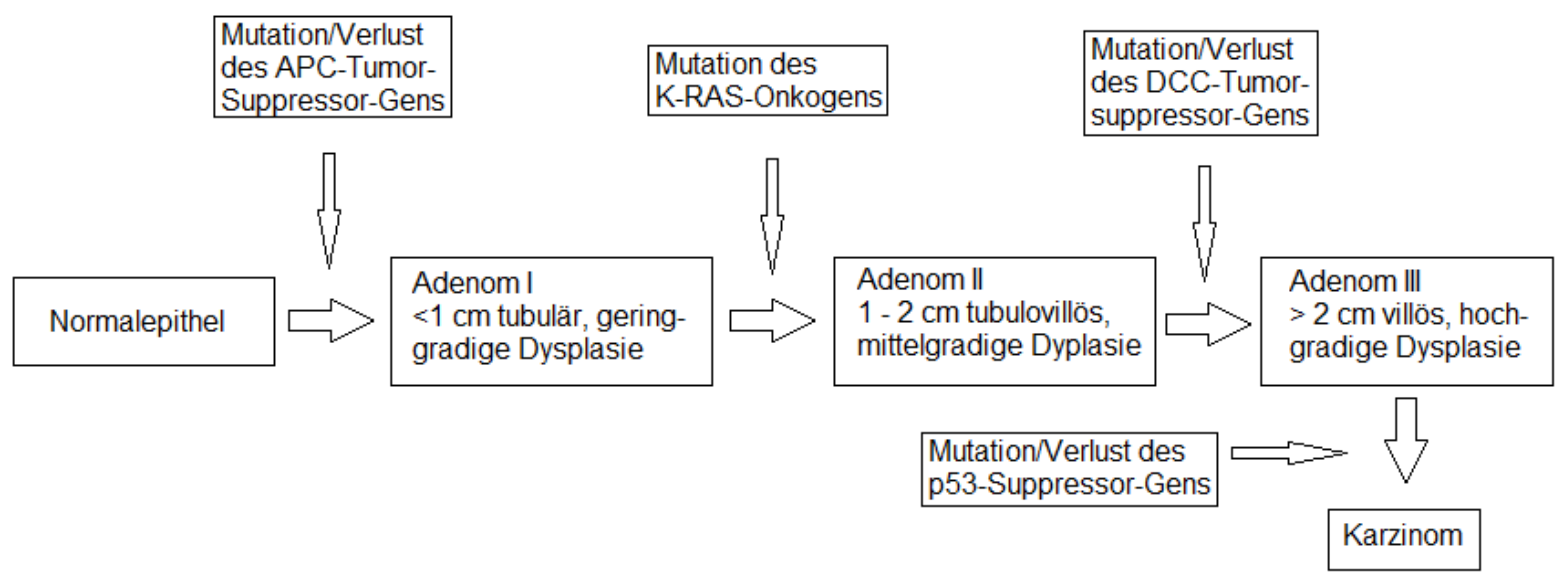

Abbildung 2: Schematisch zusammengefasste Darstellung der Adenom-Dysplasie-Karzinom-Sequenz (Fearon und Vogelstein 1990). 


\subsection{Klinische Problematik der adjuvanten und neoadjuvaten Radiochemotherapie beim Rektumkarzinom}

Die leitliniengerechte Therapie des kolorektalen Karzinoms ist je nach UICCStadium sehr differenziert und erfolgt grundsätzlich interdisziplinär. Sie hängt sowohl vom Stadium als auch von der Lokalisation des Tumors ab. Während Tumoren des Kolons und des oberen Rektumdrittels im nicht metastasierten Zustand primär operiert und in der Regel nur bei Tumorbefall der Lymphknoten $\left(\mathrm{N}_{+}\right)$adjuvant mit Chemotherapie behandelt werden (UICC III und IV), erhalten Patienten mit einem lokal-fortgeschrittenem Rektumkarzinom im mittleren und unteren Drittel eine multimodale Therapie, welche zunächst eine neoadjuvante Radiochemotherapie (RCT) gefolgt von der chirurgischen Resektion und ggf. eine adjuvante Chemotherapie beinhaltet. Die neoadjuvante RCT verringert v. a. das Risiko eines Lokalrezidivs (Sauer et al. 2014). Zudem besteht bei Karzinomen des unteren Rektumdrittels $(0-6 \mathrm{~cm}$ ab ano) häufig das Problem, dass der aborale Rand des Tumors so nah am Sphinkter ist, dass eine chirurgische Resektion nur mit dem Verlust des Sphinkters und somit der Stuhlkontinenz durchzuführen ist. Durch eine neoadjuvante RCT besteht die Möglichkeit, den Tumor so zu verkleinern, dass der Abstand für eine chirurgische Resektion mit ausreichend Sicherheitsabstand und Sphinktererhalt geschaffen wird. Das Chemotherapieregime beinhaltet eine 5-Fluoruracil-basierte Chemotherapie mit oder ohne Folinsäure bzw. Oxaliplatin. Die Radiatio hat i. d. R. eine Gesamtstrahlendosis von 50,4 Gy (verteilt auf 25 bis 28 Fraktionen). Dies entspricht einer Einzeldosis pro Bestrahlung von 1,8-2 Gy.

Eine Ausnahme besteht bei T1/2-Rektumkarzinomen mit fraglichem Lymphknotenbefall (UICC Stadium I). In dieser Situation kann erwogen werden, primär zu operieren und bei positivem Lymphknotenstatus eine Radiochemotherapie adjuvant anzuschließen (Schmiegel et al. 2010).

Trotz der einheitlichen Klassifikation und der sehr differenzierten Therapie sind die klinischen Verläufe von vergleichbaren Patienten (gleiches Stadium und vergleichbare histopathologische Parameter) sehr unterschiedlich. Die 
Spannweite der Ansprechraten auf die neoadjuvante Radiochemotherapie ist sehr groß und reicht von sehr gutem Ansprechen (complete response) bis zu weitgehender Strahlenresistenz bzw. Progress der Erkrankung unter Therapie (Ladanyi et al. 2001). Für die Patienten, die nicht ansprechen, ist es sehr fraglich, ob sie überhaupt von der Radiochemotherapie profitieren. Eine Bestrahlung im kleinen Becken kann mit erheblichen unerwünschten Wirkungen einhergehen. Zudem konnte zwar gezeigt werden, dass die multimodale Vortherapie die Inzidenz der Lokalrezidive senkt, hinsichtlich des Gesamtüberlebens ergibt sich durch die multimodale Vortherapie jedoch kein signifikanter Vorteil (Sauer et al. 2004). Auf der anderen Seite ist unklar, ob Patienten, die ein complete response unter der RCT zeigen, von der darauffolgenden Operation profitieren, denn auch diese birgt die Gefahr von einer Reihe an möglichen Komplikationen (z. B. deutlich erhöhte Stuhlfrequenz, Stuhl- und Harninkontinenz, sexuelle Dysfunktion).

Zusammenfassend erscheint es notwendig, die Mechanismen der Strahlenund Chemotherapiesensibilität sowie -resistenz besser zu verstehen, um künftig besser angepasste Therapieansätze anbieten zu können. Allerdings sei auch bereits an dieser Stelle erwähnt, dass stets der Allgemeinzustand des Patienten sowie seine Komorbiditäten und nicht zuletzt der Patientenwusch ausschlaggebend für die Wahl der individuell richtigen Therapie ist.

\subsection{Strahlenbiologie}

Unter den verschiedenen Strahlenformen ist die ionisierende Strahlung von besonderer Relevanz für biologische Prozesse, da sie dazu führen kann, das Elektronen abgespalten werden, die dann u. a. mit dem Erbgut (Desoxyribonukleinsäure, DNS) der Zelle reagieren können.

Ionisierende Strahlen wirken sowohl auf Tumorzellen, als auch auf normale Zellen schädlich. Das Ziel einer Strahlentherapie ist, Tumorzellen in hohem Maße zu schädigen und dabei umliegendes gesundes Gewebe bestmöglich zu schonen. 
Die Strahlung wirkt dabei auf verschiedene Zellbestandteile, wobei die Wirkung auf die DNS maßgeblich für den Zellschaden ist. Die Strahlenwirkung kann direkt oder indirekt, durch die Entstehung hoch reaktiver Sauerstoffradikale, auf die DNS einwirken und kann zu Einzelstrangbrüchen, Doppelstrangbrüchen, DNS-Vernetzungen (Crosslinks) und Basenschäden führen (Reiser et al. 2001).
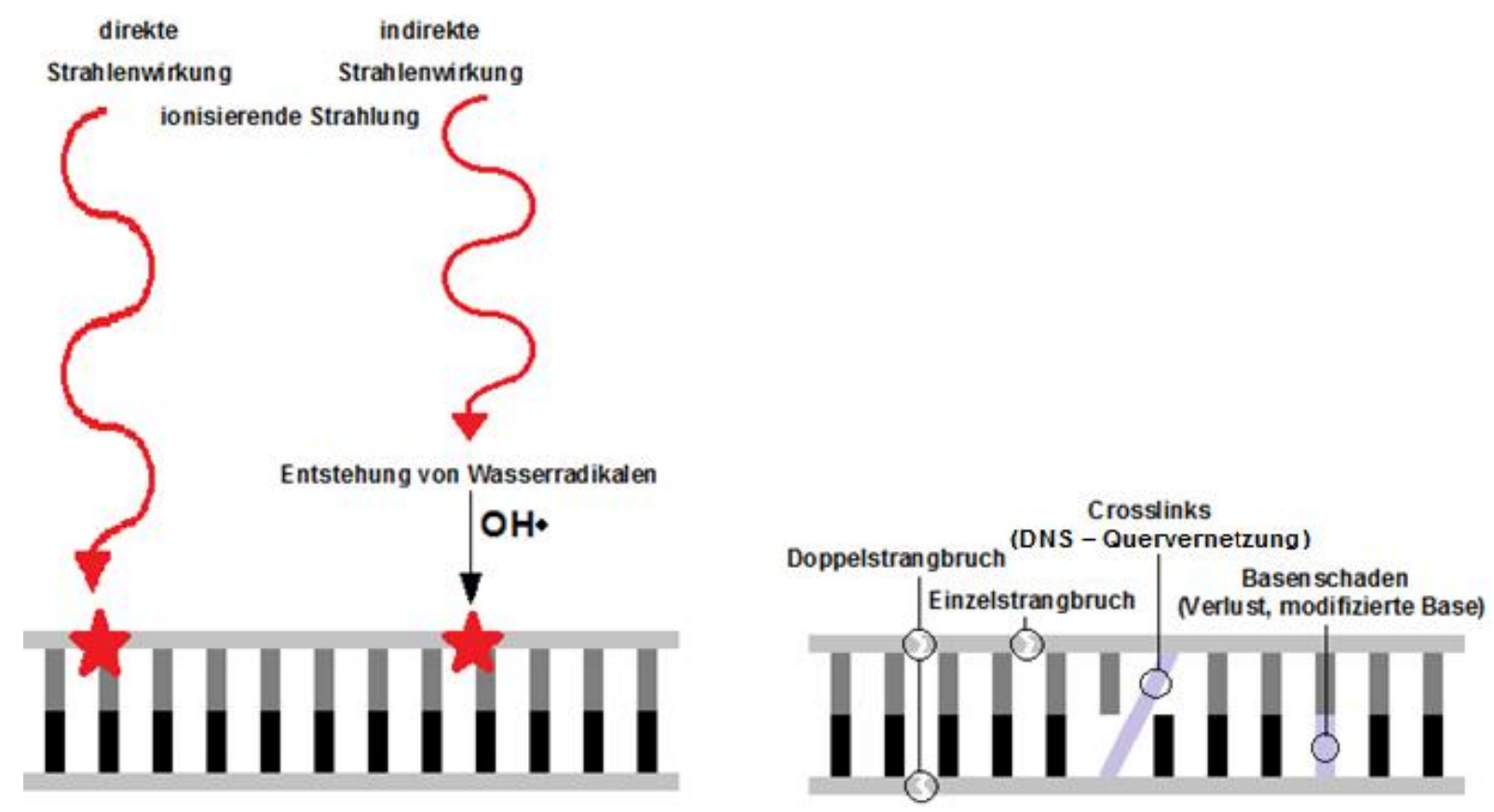

Abbildung 3: Strahlenwirkung und die resultierenden DNS-Schäden (modifiziert nach Karstens et al. und Münter et al.)

Lange Zeit ging man davon aus, Doppelstrangbrüche seien nicht reparabel. Mittlerweile ist bekannt, dass zelluläre Reparaturmechanismen diese effektiv beheben können. Akkumulieren die DNS-Schäden allerdings, kommt es in der Regel zu Zelltodinduktion. Somit ist die Anzahl auftretender Doppelstrangbrüche der maßgebende Faktor für das direkte oder indirekte Absterben der Zelle (Metheetrairut et al. 2013). Zu den strahlungsinduzierten Zelltodformen gehören die Apoptose und die Nekrose. Während die Apoptose zur Ausschüttung antientzündlicher Signale führt, wirken sich Nekrosen proentzündlich und immunaktivierend aus. Somit ist die Wirkung der Bestrahlung maßgeblich von der Interaktion mit dem Immunsystem geprägt. 
Auch spielen die jeweiligen Zellzyklusphasen eine wichtige Rolle: Die Strahlenempfindlichkeit ist im Zellzyklus während der Mitose-Phase am größten. Die Abbildung 4 stellt den Zellzyklus und die Zeitpunkte höchster Strahlenempfindlichkeit schematisch dar.

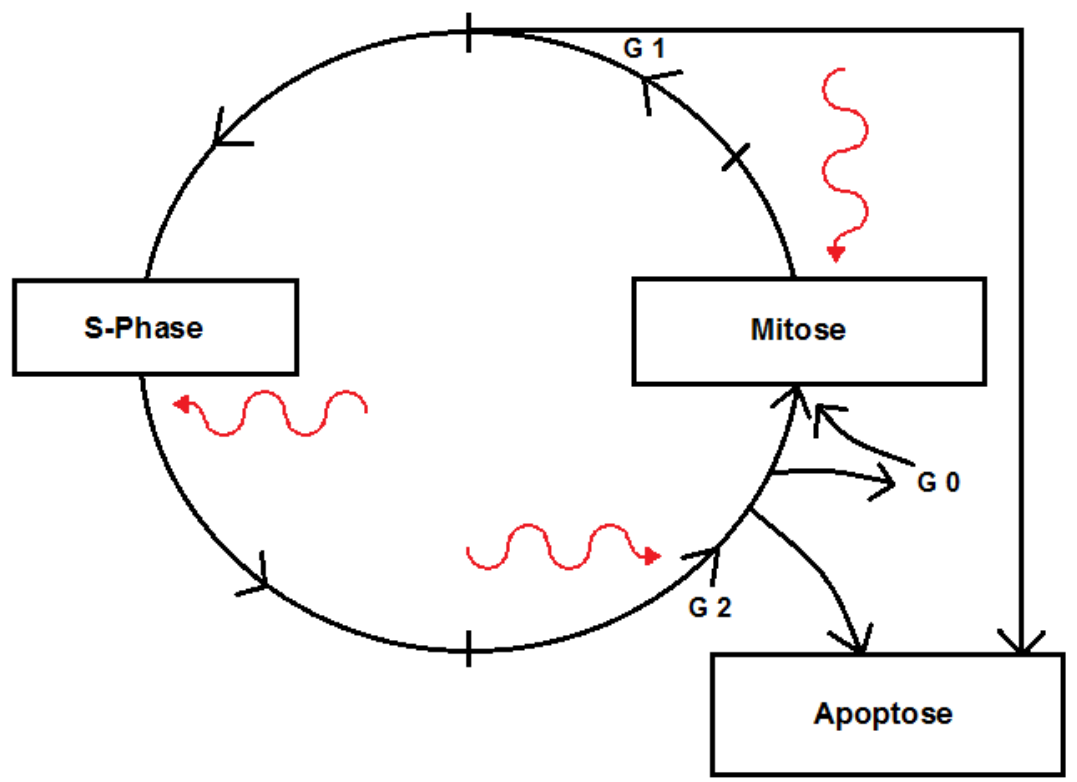

Abbildung 4: Strahlenempfindlichkeit während des Zellzyklus, die rot markierten Pfeile stellen schematisch den Zeitpunkt der Strahlenwirkung dar (modifiziert nach Karstens et al. 2010)

Das Bergonié-Tribondeau-Gesetz besagt, dass Tumorzellen mit hoher Proliferationsrate und geringem Differenzierungsgrad sensibler auf Strahlen reagieren. Jedoch gibt es undifferenzierte und schnell wachsende Tumoren, die eine hohe Strahlenresistenz aufweisen. Der Grund ist, dass es weitere Faktoren gibt, von denen die Strahlenempfindlichkeit eines Tumors abhängt, beispielsweise die genetische (intrinsische) Strahlensensibilität. Die große Spannweite der Ansprechraten von kolorektalen Karzinomen auf eine Radiochemotherapie, konnte auch bereits auf Zellkulturebene mit verschiedenen Zelllinien nachvollzogen werden (Spitzner et al. 2010).

\subsection{MicroRNAs}

Ein aussichtsreicher Diagnose- und Therapieansatz hinsichtlich der genetischen Strahlenempfindlichkeit scheint die Funktion von microRNAs in 
diesem Prozess zu sein. MicroRNAs sind einsträngige nicht-kodierende RNAs mit einer Größe von 18 bis 23 Nukleotiden, welche die Genexpression auf post-transkriptionaler Ebene hochspezifisch regulieren, indem sie an die entsprechende mRNA-Sequenz binden und dadurch eine Translation des jeweiligen Gens in ein Protein verhindern (RNA-Interferenz).

Die Informationen hierzu liegen, wie auch bei den anderen RNA-Formen, in dem Genom. Hierzu synthetisieren die RNA-Polymerasen II und III zunächst die pri-miRNA (primary microRNA). Das Primärtranskript wird dann durch die RNase III (Drosha) zu einer etwa 70-80 Nukleotiden umfassenden precursor microRNA (pre-miRNA) prozessiert. Die entstandene pre-miRNA gelangt schließlich mithilfe von Exportin-5 über die Kernporen ins Zytoplasma. Hier erfolgt eine weitere Prozessierung durch das Enzym Dicer zu einer doppelsträngigen microRNA (ds-miRNA), welche an sich dann schon die endgültige Länge bzw. Anzahl an Nukleotiden enthält. Nachfolgend wird die ds-miRNA entwunden und zu einem Einzelstrang aufgespalten. Bei manchen microRNAs existieren zwei gleich lange Sequenzen, die von demselben vorhergesagten Vorläufer stammen. Wenn die Daten nicht ausreichend hergeben können, welche Sequenz die vorherrschende ist, werden Namen wie miR-127-5p (vom 5'-Arm) und miR-127-3p (vom 3'-Arm) vergeben (Kim und Nam 2006). 


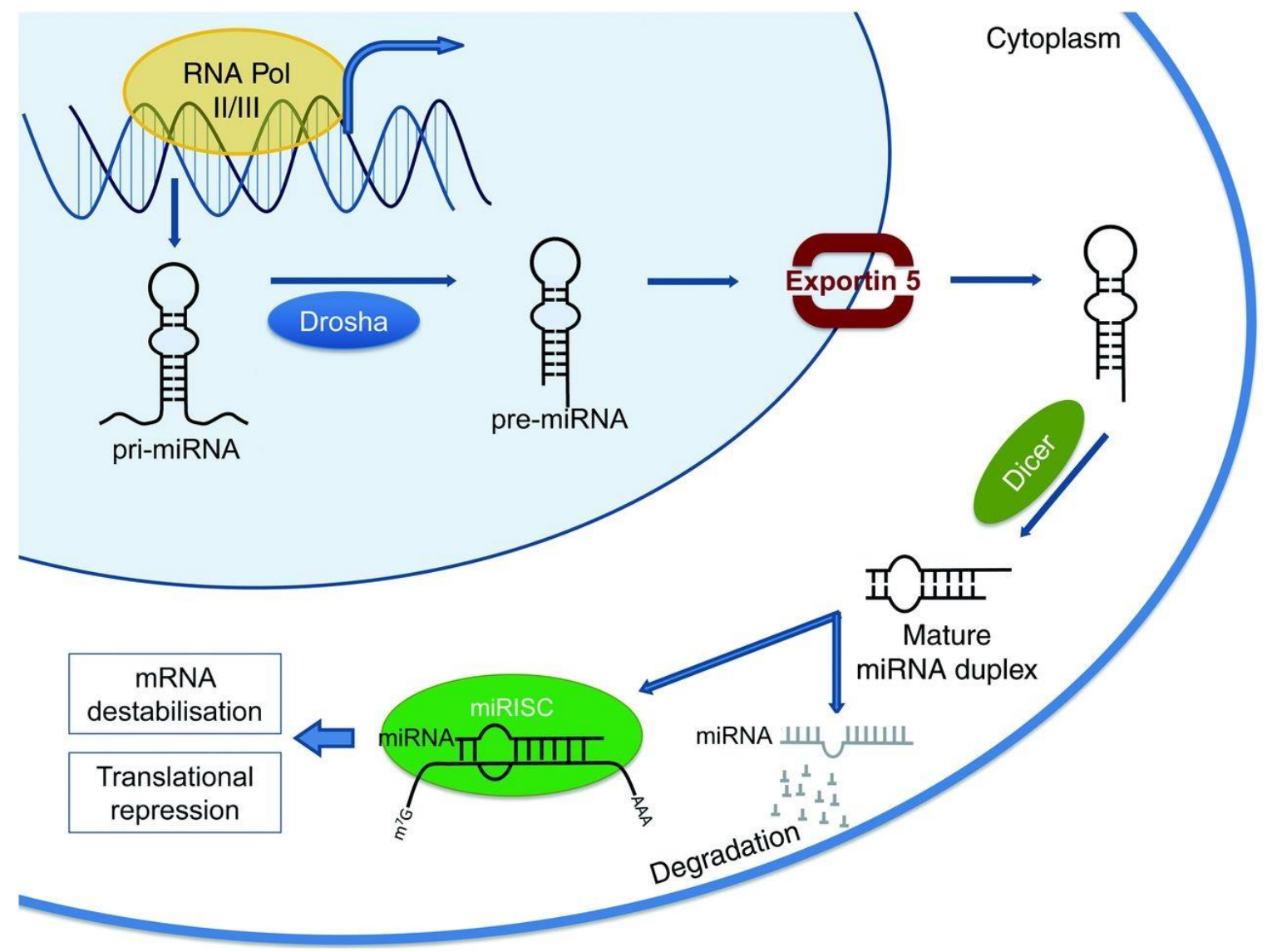

Abbildung 5: Schematische Darstellung der microRNA-Synthese von der Erstellung der pri-miRNA bis hin zur microRNA über die aufgeführten Enzyme (Donadeu et al. 2012)

Diese Moleküle wurden 1993 erstmals beschrieben (Lee et al. 1993) und es sind mittlerweile viele hundert verschiedene von innen bekannt. In einer bereits abgeschlossenen Forschungsarbeit konnte eine microRNAExpressions-Signatur, hinsichtlich Sensibilität und Resistenz gegenüber Radiochemotherapie bei kolorektalen Tumorzellen, erstellt werden (Salendo et al. 2013).

\subsection{Zielsetzung und Fragestellung}

Trotz der einheitlichen Klassifikation und der sehr differenzierten Therapie sind die klinischen Verläufe von vergleichbaren Patienten sehr unterschiedlich. Die Spannweite der Ansprechraten auf die neoadjuvante Radiochemotherapie ist sehr groß und reicht von vollständiger Remission bis zu weitgehender Strahlenresistenz (Ladanyi et al. 2001). 
Ein Maß hierzu bietet der Tumorregressionsgrad (TRG), bei dem der vitale Tumoranteil und der Fibrosegrad bei der histopathologischen Begutachtung am Resektat beurteilt werden. In der Literatur werden unterschiedliche Regressionsgrade vorgeschlagen, wobei diejenigen von Dworak und Mandard am häufigsten Verwendung finden (Tischoff und Tannapfel 2012). Ein ungünstiger Regressionsgrad (TRG1) mit überwiegen der vitalen Tumoranteile stellt ein erhöhtes Risiko für ein Tumorrezidiv dar und besitzt diesbezüglich sogar Vorhersagekraft (Trakarnsanga et al. 2014).

Aus den genannten Gründen ist es notwendig, die Mechanismen der Strahlensensibilität und -resistenz besser zu verstehen, um bessere Diagnosesowie Therapieansätze anbieten zu können. Im Rahmen dieses Bestrebens war die zugrundeliegende Hypothese dieser Arbeit, dass es entweder eine kleine Population maligner Zellklone gibt, welche durch die höhere Expression bestimmter microRNAs eine Radiochemotherapie besser überleben, oder, dass solche resistenteren Zellklone unter der Therapie entstehen können (siehe auch Abbildung 6).

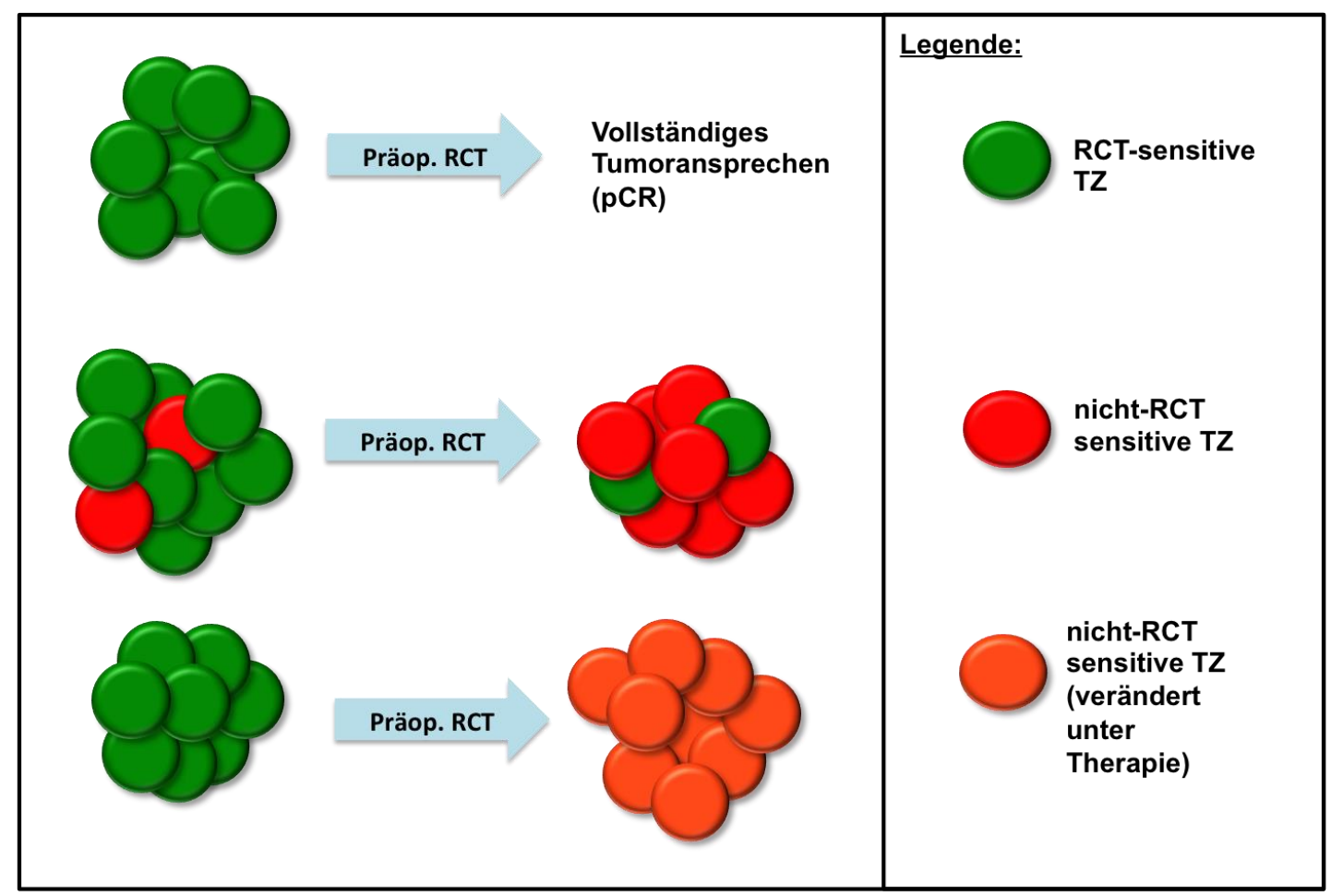

Abbildung 6: Mögliche Reaktion der Tumorzellen auf Radiochemotherapie (eigene Abbildung) 
Ziel dieser Studie war es, microRNAs zu identifizieren, welche potentiell an der Resistenzvermittlung gegenüber einer Radiochemotherapie beteiligt sein könnten. Hierzu erfolgte in einer Vorarbeit zunächst eine genomweite microRNA-Analyse an Tumorgewebe von 14 Patienten vor und nach neoadjuvanter Radiochemotherapie per Micro-Array (Experimente nicht Bestandteil der vorliegenden Dissertation). Anschließend sollten die zehn relevantesten microRNAs, welche nach erfolgter Radiochemotherapie eine deutlich höhere Expression aufwiesen, an 32 Patienten per quantitativer realtime RT-PCR validiert werden. Zur funktionellen Bestätigung wurden ausgewählte microRNAs in SW480-Zellen transfiziert, darauf folgend Koloniebildungstest durchgeführt und die Überlebensfraktion nach Bestrahlung

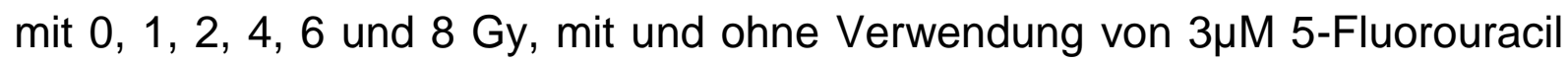
(5-FU), verglichen.

Die definierten Ziele lassen sich kurz wie folgt zusammenfassen:

- Identifikation von microRNAs, die in der prätherapeutischen Biopsie wesentlich geringer als im residuellen Tumor exprimiert sind

- Validierung der Array-Analysen in Gewebeproben von 32 Patienten mittels PCR

- Überprüfung der funktionellen Relevanz dieser microRNAs in einem Koloniebildungstest

- Vergleich der Ergebnisse mit den klinisch-pathologischen Patientendaten 


\section{Material und Methoden}

\subsection{Material}

\subsubsection{Verbrauchsmaterialien}

Auslaufpipetten, serologische

Einfrierröhrchen

Einmalreagenzreservoirs, steril

Flüssigkeitsreservoirs, Rotilabo ${ }^{\circledR} \mathrm{PVC}$

Pasteurpipetten, glas

Pipettenspitze (10ml), für Multipette ${ }^{\circledR}$

Stream

Pipettenspitzen, Safe Seal-Tips ${ }^{\circledR}$

professional

Pipettenspitzen, Tip One ${ }^{\circledR}(10,200$ und $1000 \mu \mathrm{l})$, steril

Pipettenspitzen, Tip One $\left.{ }^{(}\right)(10,200,300$ und $1000 \mu \mathrm{l})$

Pipettenspitzen für PCR, Integrity Filter Tips, $12,5 \mu \mathrm{l}$

Pipettenspitzen für PCR, Integrity Filter Tips $125 \mu \mathrm{l}$

Platten, 6-Well Cyto One ${ }^{\circledR}$, steril

Platten, 96-Well Cyto One ${ }^{\circledR}$, steril

Platten, 384-Well PCR Plate
STARLAB GmbH, Hamburg,

Deutschland TPP, Trasadingen, Schweiz

Carl Roth GmbH \& Co. KG, Karlsruhe, Deutschland

Carl Roth GmbH \& Co. KG, Karlsruhe, Deutschland Brand GmbH \& Co. KG, Wertheim, Deutschland

Eppendorf AG, Hamburg, Deutschland

Biozym Scientific GmbH, Hessisch

Oldendorf, Deutschland

STARLAB GmbH, Hamburg,

Deutschland

STARLAB GmbH, Hamburg,

Deutschland

Thermo Fisher Scientific Inc., Waltham, MA, USA

Thermo Fisher Scientific Inc., Waltham, MA, USA

STARLAB GmbH, Hamburg,

Deutschland

STARLAB GmbH, Hamburg,

Deutschland

Thermo Fisher Scientific Inc., Waltham, 


\begin{tabular}{|c|c|}
\hline & MA, USA \\
\hline $\begin{array}{l}\text { Reagiergefäße Biosphere }{ }^{\circledR} \text { Safe Seal } \\
(1,5 \mathrm{ml})\end{array}$ & $\begin{array}{l}\text { Sarstedt AG \& Co., Nümbrecht, } \\
\text { Deutschland }\end{array}$ \\
\hline Reaktionsgefäße (1,5 ml) & $\begin{array}{l}\text { Carl Roth GmbH \& Co. KG, Karlsruhe, } \\
\text { Deutschland }\end{array}$ \\
\hline Reaktionsgefäße (2 ml) & Eppendorf AG, Hamburg, Deutschland \\
\hline Röhrchen, Falcon Tube (15 und 50 ml) & $\begin{array}{l}\text { Sarstedt AG \& Co., Nümbrecht, } \\
\text { Deutschland }\end{array}$ \\
\hline Transferpipetten (3,5 ml) & $\begin{array}{l}\text { Sarstedt AG \& Co., Nümbrecht, } \\
\text { Deutschland }\end{array}$ \\
\hline
\end{tabular}

Zellkulturflaschen Cyto One $\left.{ }^{(}\right)(25,75$ und

STARLAB GmbH, Hamburg Deutschland $225 \mathrm{~cm}^{2}$ )

Zellschaber, $300 \mathrm{~mm}$

TPP, Trasadingen, Schweiz

Zellspachtel, $195 \mathrm{~mm}$

TPP, Trasadingen, Schweiz

\subsubsection{Chemikalien}

2-Propanol

Ammoniumpersulfat (APS)

Bovines Serumalbumin (BSA)

Brilliant Blau R250 Tabletten

Bromphenolblau-Lösung

Essigsäure 100\% Ph. Eur.,reinst

Ethanol, ROTIPURAN ${ }^{\circledR} \geq 99,8 \%$
1,4-Dithio-DL-threit(ol) (DTT)

AppliChem GmbH, Darmstadt, Deutschland

Merck KGaA, Darmstadt, Deutschland AppliChem GmbH, Darmstadt,

Deutschland

AppliChem GmbH, Darmstadt,

Deutschland

Merck KGaA, Darmstadt, Deutschland

AppliChem GmbH, Darmstadt,

Deutschland

Carl Roth GmbH \& Co. KG, Karlsruhe, Deutschland

Carl Roth GmbH \& Co. KG, Karlsruhe, Deutschland

Ethylendiamintetraessigsäure (EDTA), Quality Biological Inc., Gaithersburg, MD, $0,5 \mathrm{M}, \mathrm{pH}=8,0$ USA

Glycin
Sigma-Aldrich, St. Louis, MO, USA 
Methanol, ROTIPURAN ${ }^{\circledast}, \geq 99,9 \%$

Natriumazid $\left(\mathrm{NaN}_{3}\right)$, reinst

Natriumchlorid $(\mathrm{NaCl}), \geq 99,5 \%$

Natriumdodecylsulfat (SDS)-Lösung 10\% für die Molekularbiologie

Natriumhydroxid ( $\mathrm{NaOH}$ ) Plätzchen

Nonidet ${ }^{(}$P40 (NP40)

Phosphatase-Inhibitor Cocktail

Tabletten, PhosSTOP

Protease-Inhibitor Cocktail, Protease

Block $^{\mathrm{TM}}$

Rotiphorese ${ }^{\circledR}$ Gel30 Lösung

Salzsäure (HCl) 5M

Tris ultrapure

Tween ${ }^{\circledR} 20$
Carl Roth GmbH \& Co. KG, Karlsruhe, Deutschland

Merck KGaA, Darmstadt, Deutschland Carl Roth GmbH \& Co. KG, Karlsruhe, Deutschland

AppliChem GmbH, Darmstadt,

Deutschland

Merck KGaA, Darmstadt, Deutschland AppliChem GmbH, Darmstadt, Deutschland

Roche Diagnostics $\mathrm{GmbH}$, Mannheim, Deutschland

Fermentas GmbH, St. Leon-Rot, Deutschland Carl Roth GmbH \& Co. KG, Karlsruhe, Deutschland

Merck KGaA, Darmstadt, Deutschland AppliChem GmbH, Darmstadt,

Deutschland

Sigma-Aldrich, St. Louis, MO, USA

\subsubsection{Geräte}

Autoklav, HST 32/25

Zirbus technology GmbH, Bad Grund/ Harz, Deutschland

Bestrahlungsgerät,

Xstrahl RS225 X-Ray irradiator

Gulmay Medical Itd, Camberley (Surray),

Colony Counter, eCount ${ }^{\mathrm{TM}}$

United Kingdom

Heathrow Scientific $\left.{ }^{(}\right)$LLC, Nottingham, United Kingdom

CFX384-Termocycler

Bio-Rad $^{\circledR}$, Hercules, CA, USA

Freezing Container, 5100 Cryo $1^{\circ} \mathrm{C}$, "Mr. Thermo Fisher Scientific Inc., Waltham, Frosty" MA, USA

Heißluftsterilisator, Heraeus ST6060

Thermo Fisher Scientific Inc., Waltham, MA, USA 
Inkubator $\mathrm{CO}_{2}$, Incubator $\mathrm{C} 200$

Inkubator, Water-Jacketed Incubator 3250

Magnetrührer

Mikroskop, invers, Leica DM IL

Mikroskop, Leica S6 E

Mikroskopkamera, High-speed Leica

EC3

Multilabel Plate Reader, Victor ${ }^{\mathrm{TM}} \mathrm{X} 4$

Netzgerät, PowerPac 3000

Netzgerät, Standard Power Pack P25

pH-Meter, PB-11

Pipette, elektrisch, 8-Kanal Research pro 50-1200 $\mu \mathrm{l}$

Pipette, Multipette ${ }^{\circledR}$ Stream

Pipetten, Eppendorf Reference

Pipettierhelfer, accu-jet ${ }^{(}$

Präzisionswaage, BP 610

Präzisionswaage, ED224S

Real-Time System CFX384

Schüttler, MS 3 digital

Silikonabdichtung, 1,0mm, für Minigel Sterilbank, SterilGARD Hood Class II Typ A/B3

Thermomixer, comfort

Thermal Cycler C1000

Transfektionsgerät, Nucleofactor ${ }^{\mathrm{TM}} 2 \mathrm{~b}$

Device

Vortexer, IKA ${ }^{\Theta}$ MS1 Shaker
Labotect GmbH, Göttingen, Deutschland

Forma Scientific Inc., Marietta, OH, USA

IKA ${ }^{\circledR}$-Werke GmbH \& Co. KG, Staufen,

Deutschland

Leica AG, Wetzlar, Deutschland

Leica AG, Wetzlar, Deutschland

Leica AG, Wetzlar, Deutschland

PerkinEImer, Waltham, MA, USA

Bio-Rad Laboratories $\mathrm{GmbH}$, München, Germany

Biometra $\mathrm{GmbH}$, Göttingen, Deutschland Sartorius AG, Göttingen, Deutschland Eppendorf AG, Hamburg, Deutschland

Eppendorf AG, Hamburg, Deutschland Eppendorf AG, Hamburg, Deutschland Brand GmbH \& Co. KG, Wertheim, Deutschland

Sartorius AG, Göttingen, Deutschland Sartorius AG, Göttingen, Deutschland Bio-Rad $^{\circledR}$, Hercules, CA, USA IKA ${ }^{\Theta}$-Werke GmbH \& Co. KG, Staufen, Deutschland

Biometra GmbH, Göttingen, Deutschland The Baker Company, Sanford, ME, USA

Eppendorf AG, Hamburg, Deutschland Bio-Rad $^{\circledR}$, Hercules, CA, USA Lonza Cologne $\mathrm{GmbH}$, Köln, Deutschland IKA ${ }^{\Theta}$-Werke GmbH \& Co. KG, Staufen, Deutschland 
Wasserbad, GFL 1003

Water Purification System, Milli-Q

Reference Ultrapure

Wippschüttler, WS42

Zählkammer, Neubauer improved

Zentrifuge, Heraeus Fresco 17

Zentrifuge, Heraeus Labofuge $400 \mathrm{R}$

Zentrifuge, Mini, Rotilabo ${ }^{\circledR}$
Gesellschaft für Labortechnik mbH, Burgwedel, Deutschland Merck Millipore, Billerica, MA, USA

A. Hartenstein Gesellschaft für Labor- und Medizintechnik mbH, Würzburg/ Versbach, Deutschland Brand GmbH \& Co. KG, Wertheim, Deutschland Thermo Fisher Scientific Inc., Waltham, MA, USA

Thermo Fisher Scientific Inc., Waltham, MA, USA

Carl Roth GmbH \& Co. KG, Karlsruhe, Deutschland 


\subsubsection{Zellkulturreagenzien}

0,25\% Trypsin -EDTA (1x)

Fetal Bovine Serum (FBS)

L-Glutamine $200 \mathrm{mM}$ in $0,85 \% \mathrm{NaCl}$

Solution

Nährmedium, Leibovitz's L-15 Medium

Nährmedium, RPMI Medium 1640

Phosphate Buffered Saline (PBS) pH 7,2

Trypan Blue solution 0,4\%

Bad Stabil Konzentrat
Gibco $^{(}$by life technologies ${ }^{\mathrm{TM}}$, Carlsbad, CA, USA

Biochrom AG, Berlin, Deutschland Boehringer Ingelheim GmbH \& Co.KG, Ingelheim, Deutschland Gibco $^{\circledR}$ by life technologies ${ }^{\mathrm{TM}}$, Carlsbad, CA, USA

Gibco $^{(\Theta}$ by life technologies ${ }^{\mathrm{TM}}$, Carlsbad, CA, USA

Gibco $\left.{ }^{(}\right)$by life technologies ${ }^{\mathrm{TM}}$, Carlsbad, CA, USA

Sigma-Aldrich, St. Louis, MO, USA neoLab Migge Laborbedarf-Vertriebs $\mathrm{GmbH}$, Heidelberg, Deutschland

\subsubsection{Kits}

Amaxa $^{\mathrm{TM}}$ Cell Line Nucleofector ${ }^{\mathrm{TM}} \mathrm{Kit} \mathrm{V}$ Lonza Cologne $\mathrm{GmbH}$, Köln, (25 RCT) Deutschland miScript SYBR® Green PCR-Kit Qiagen, Venlo, Niederlande RT-II-Kit ${ }^{\circledR}$ Qiagen, Venlo, Niederlande

\subsubsection{Primer}

Ein bereits abgeschlossener Vorversuch der Forschungsgruppe KFO 179 befasste sich mit Micro-Array-Analysen zur Expression bestimmter microRNAs in Gewebeproben von Patienten, die eine Vorbehandlung mit 5-FU bzw. Oxaliplatin + 5-FU erhalten haben (siehe unten). Auf Grundlage dieser Daten wurden Primer für eine entsprechende PCR-Validierung ausgewählt. 


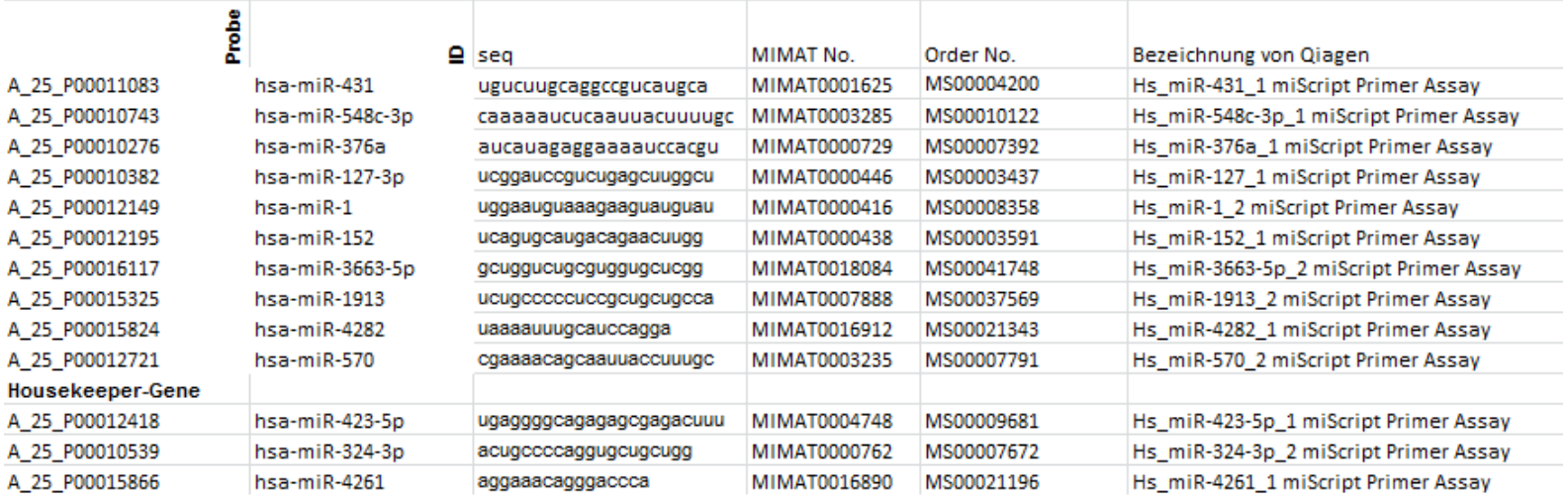

Abbildung 7: Auflistung der verwendeten Primer der Firma Qiagen ${ }^{\circledR}$ - neben der Nummerierung der einzelnen Primer und der entsprechenden Katalognummer, ist in der dritten Spalte die jeweilige Basenabfolge aufgeführt

\subsection{7 miRNAs/Mimics}

\begin{tabular}{l|l|l} 
Produktname & Sequenz & Kat.Nr. (Qiagen) \\
\hline Syn-hsa-miR-1 miScript miRNA Mimic & UGGAAUGUAAAGAAGUAUGUAU & MSY0000416 \\
\hline Syn-hsa-miR-152-3p miScript miRNA Mimic & UCAGUGCAUGACAGAACUUGG & MSY0000438 \\
\hline Syn-hsa-miR-376a-3p miScript miRNA Mimic & AUCAUAGAGGAAAAUCCACGU & MSY0000729 \\
\hline Syn-hsa-miR-127-3p miScript miRNA Mimic & UCGGAUCCGUCUGAGCUUGGCU & MSY0000446
\end{tabular}

Abbildung 8: Auflistung der verwendeten Mimics (Bezeichnung für synthetisch hergestellte microRNAs) der Firma Qiagen ${ }^{\circledR}$ mit entsprechender Katalognummer und Aufführung der Basenabfolge

\subsubsection{Puffer und Lösungen}

\section{Tris buffered saline (TBS) Puffer}

Reagenzien

Tris ultrapure

$\mathrm{NaCl}$
Endkonzentration

$50 \mathrm{mM}$

$150 \mathrm{mM}$
Für $1000 \mathrm{ml}$

$6,057 \mathrm{~g}$

$8,766 \mathrm{~g}$

Reagenzien in $\mathrm{ddH}_{2} \mathrm{O}$ lösen und pH-Wert auf 7,5 einstellen, dann $\mathrm{ddH}_{2} \mathrm{O}$ hinzufügen, bis das Zielvolumen von $1000 \mathrm{ml}$ erreicht ist.

Tris buffered saline $+\mathbf{0 , 1} \%$ Tween $\AA 20$ (TBS-T) Puffer

Reagenzien

TBS

Tween ${ }^{\circledR} 20$

Nonidet@ P40 (NP40) Zelllysepuffer

Reagenzien

$1 \mathrm{M}$ Tris ultrapure

\section{Endkonzentration}

$0,1 \%$

Endkonzentration

$50 \mathrm{mM}$
Für $1000 \mathrm{ml}$

$999 \mathrm{ml}$

$1 \mathrm{ml}$ 


$\begin{array}{llr}5 \mathrm{M} \mathrm{NaCl} & 150 \mathrm{mM} & 3 \mathrm{ml} \\ \text { Nonidet }^{\circledR} \text { P40 (NP40) } & 1 \% & 1 \mathrm{ml}\end{array}$

Reagenzien in $\mathrm{ddH}_{2} \mathrm{O}$ lösen und pH-Wert auf 7,8 einstellen, dann $\mathrm{ddH}_{2} \mathrm{O}$ hinzufügen, bis das Zielvolumen von $100 \mathrm{ml}$ erreicht ist.

\subsubsection{Computer Software}

Grapher $^{\text {TM }} 8$

ImageJ

Microsoft Office 2010

EndNote X4

KaleidaGraph Vers. 4.1.0

Adobe Reader X
Golden Software Inc., Golden, CO, USA

National Institutes of Health $(\mathrm{NIH})$,

Bethesda, MD, USA

Microsoft Corporation, Redmond, WA, USA

Thomson Reuters, New York, NY, USA

Synergy Software, Reading, PA, USA

Adobe, San Jose, CA, USA

\subsubsection{Patientenkollektiv}

Die Proben stammten, mit entsprechendem Einverständnis, von Rektumkarzinompatienten, die im Rahmen der CAO-04-Studie (Studiennummer NCT 00349076) in der Abteilung für Allgemein- und Viszeralchirurgie in der Universitätsklinik Göttingen behandelt wurden.

Das Patientenkollektiv umfasst 9 weibliche und 23 männliche Patienten bei einem Durchschnittsalter von 65,75 Jahren (zum Zeitpunkt der Diagnosestellung, siehe Tabelle 3). 


\begin{tabular}{|c|c|c|c|c|c|c|c|c|c|c|c|c|}
\hline Patient & Geschlecht & $\begin{array}{l}\text { Alter zum } \\
\text { Zeitpunkt } \\
\text { Biopsie }\end{array}$ & uT & uN & $\underset{\text { initial }}{M}$ & pT & $\begin{array}{c}\text { pT } \\
\text { simple }\end{array}$ & pN simple & $M$ & \begin{tabular}{|r|} 
UICC \\
(Stand \\
2013 )
\end{tabular} & TRG & $\begin{array}{r}\text { TRG } \\
\%\end{array}$ \\
\hline P0317 & weiblich & 71 & 3 & 1 & 0 & $3 c$ & 3 & 2 & 0 & III B & $3 b$ & $90 \%$ \\
\hline P0331 & männlich & 74 & 3 & 1 & 0 & 2 & 2 & 0 & 0 & 1 & 2 & $\mathrm{n} / \mathrm{a}$ \\
\hline P0315 & männlich & 71 & 3 & 1 & 0 & 3 & 3 & 1 & 1 & III B & 2 & $40 \%$ \\
\hline P0054 & weiblich & 72 & 3 & 1 & 0 & 2 & 2 & 0 & 0 & 1 & $3 b$ & $95 \%$ \\
\hline P0358 & männlich & 52 & 3 & 1 & 0 & 2 & 2 & 0 & 0 & $\mathrm{I}$ & 2 & $50 \%$ \\
\hline P1207 & männlich & 77 & 3 & 1 & 0 & $3 b$ & 3 & 1 & 0 & III & 2 & $80 \%$ \\
\hline P0276 & weiblich & 73 & 3 & 1 & 0 & $3 b$ & 3 & 0 & 1 & II A & 2 & $70 \%$ \\
\hline P0172 & männlich & 63 & 3 & 0 & 0 & $3 a$ & 3 & 0 & 0 & II A & 3 & $80 \%$ \\
\hline P0173 & männlich & 71 & 3 & 1 & 1 & 2 & 2 & 0 & 1 & IV & $3 b$ & $80 \%$ \\
\hline P0229 & weiblich & 55 & 3 & 1 & 0 & $3 d$ & 3 & 1 & 0 & III B & 1 & $20 \%$ \\
\hline $\mathrm{P} 0070$ & weiblich & 80 & 3 & 1 & 0 & 2 & 2 & 0 & 0 & $\mathrm{I}$ & $3 a$ & $55 \%$ \\
\hline P0055 & männlich & 59 & 3 & 1 & 0 & $3 c$ & 3 & 1 & 0 & III B & $3 a$ & $75 \%$ \\
\hline P0123 & männlich & 55 & 3 & 1 & 0 & $3 b$ & 3 & 1 & 1 & IV & $3 a$ & $70 \%$ \\
\hline $\mathrm{P} 0130$ & männlich & 64 & 3 & 1 & 0 & 2 & 2 & 0 & 0 & $\mathrm{I}$ & 2 & $50 \%$ \\
\hline P0073 & männlich & 58 & 3 & 1 & 0 & 2 & 2 & 0 & 0 & $\mathrm{I}$ & $3 b$ & $95 \%$ \\
\hline P0160 & männlich & 60 & 3 & 1 & 0 & $3 b$ & 3 & 1 & 0 & III B & $3 b$ & $90 \%$ \\
\hline $\mathrm{P} 0327$ & männlich & 54 & 3 & 1 & 0 & $4 a$ & 4 & 1 & 1 & IV & 2 & $\mathrm{n} / \mathrm{a}$ \\
\hline P0301 & männlich & 75 & 3 & 1 & 0 & $3 a$ & 3 & 1 & 1 & III B & 2 & $70 \%$ \\
\hline P0360 & männlich & 69 & 3 & 1 & 0 & 2 & 2 & 1 & 0 & III A & 2 & $80 \%$ \\
\hline P0385 & weiblich & 73 & 3 & 1 & 0 & $3 b$ & 3 & 2 & 0 & III B & 1 & $25 \%$ \\
\hline P1219 & männlich & 75 & 3 & 0 & 0 & 2 & 2 & 0 & 0 & $\mathrm{I}$ & 2 & $\mathrm{n} / \mathrm{a}$ \\
\hline P0014 & männlich & 59 & 3 & 1 & 0 & $4 a$ & 3 & 1 & 1 & III B & 2 & $30 \%$ \\
\hline P0018 & weiblich & 61 & 3 & 1 & 0 & 4 & 4 & 1 & 1 & III B & 1 & $20 \%$ \\
\hline P0022 & männlich & 62 & 3 & 0 & 0 & $3 a$ & 3 & 0 & 1 & II A & 1 & $15 \%$ \\
\hline P0133 & männlich & 75 & 4 & 1 & 0 & 3 & 3 & 0 & 0 & II A & 2 & $45 \%$ \\
\hline P0067 & männlich & 67 & 3 & 1 & 0 & 1 & 1 & 0 & 0 & 1 & 1 & $20 \%$ \\
\hline $\mathrm{P} 0111$ & männlich & 57 & 3 & 0 & 0 & $3 c$ & 3 & 0 & 0 & II A & 1 & $20 \%$ \\
\hline P0152 & weiblich & 50 & 3 & 1 & 0 & $4 a$ & 4 & 0 & 0 & II B & 1 & $40 \%$ \\
\hline P0288 & weiblich & 73 & 3 & 1 & 0 & 2 & 2 & 0 & 0 & $\mathrm{I}$ & $3 a$ & $70 \%$ \\
\hline P0069 & männlich & 70 & 3 & 1 & 0 & $3 b$ & 3 & 1 & 1 & III B & 2 & $50 \%$ \\
\hline P0155 & männlich & 68 & 3 & 0 & 0 & $3 b$ & 3 & 1 & 1 & III B & $3 a$ & $70 \%$ \\
\hline P0139 & männlich & 61 & 3 & 1 & 0 & $3 c$ & 3 & 1 & 0 & III B & $3 a$ & $80 \%$ \\
\hline
\end{tabular}

Tabelle 3: Patientenkollektiv - aufgeführt wird die anonymisierte Patientennummer, das Geschlecht, das Alter und klinische sowie pathologische Parameter 


\subsection{Methoden}

\subsubsection{Zellkultur}

Um die Kontamination der Proben zu vermeiden, erfolgte die Durchführung der Zellkulturarbeiten an einer Sterilbank. Die Zellen wurden den von der ATCC empfohlenen Protokollen entsprechend behandelt.

Nachfolgend eine Zusammenfassung der Wachstumsvoraussetzungen der verwendeten Zelllinie:

\begin{tabular}{|l|l|l|l|l|l|l|}
\hline Zelllinie & Ursprung & $\hat{\partial} / q$ & Medium & Wachstum & $\mathrm{CO}_{2} / \mathrm{O}_{2}$ & ATCC Nr. \\
\hline SW480 & human & $\hat{\sigma}$ & Leibovitz's L-15 & adhärent & Raumluft & CCL-228 \\
\hline
\end{tabular}

Tabelle 4: Wachstumsvoraussetzungen der verwendeten Zelllinie; kultiviert im Inkubator bei $37^{\circ} \mathrm{C}$

Den verwendeten Medien wurden jeweils $10 \%$ FBS und $1 \%$ Glutamin beigemischt. Alle 48 Stunden wurden die Zellen mikroskopisch beurteilt und je nach Zustand einem Medienwechsel, oder (bei einer Konfluenz von ca. 70 bis $80 \%)$ einem Splitting unterzogen. Erreichten die Zellen die logarithmische Wachstumsphase, konnten sie für Versuche verwendet werden.

\subsubsection{Auftauen asservierter Zelllinien}

Alle Zelllinien werden bei $-150{ }^{\circ} \mathrm{C}$ im Gefrierschrank gelagert. Zum Auftauen wurde das Reaktionsgefäß für wenige Minuten bei $37^{\circ} \mathrm{C}$ ins Wasserbad gestellt. Unter Verwendung einer Transferpipette wurden die Zellen anschließend in ein 15-ml-Röhrchen mit $10 \mathrm{ml}$ Medium überführt. Nach fünfminütiger Zentrifugation bei $800 \mathrm{rcf}$ und Absaugen des Überstandes, konnte die Kultivierung mit dem Zellpellet und $5 \mathrm{ml}$ neuem Medium (zunächst in einem T-25-Behälter) gestartet werden. Nach 24 Stunden erfolgte eine mikroskopische Beurteilung und in Abhängigkeit von der Konfluenz wurde entweder das Medium gewechselt oder die Zellen gesplittet. 


\subsubsection{Mediumwechsel}

Für Zellen, die aus einem Organismus isoliert wurden, müssen bestimmte Bedingungen geschaffen werden, wenn sie In-vitro kultiviert werden sollen. Hierzu dient in der Regel gebrauchsfertig hergestelltes Medium.

Durch die üblichen Stoffwechselprozesse und die mehr oder weniger ablaufenden Zellteilungen werden die Nährstoffe des Mediums verbraucht und es fallen zunehmend Stoffwechselendprodukte an. Daher war es nötig, in gewissen Abständen neues Medium hinzuzufügen oder dieses ganz auszutauschen. Letztere Option wird nachfolgend kurz erläutert:

- Altes Medium mit Pasteur-Pipette absaugen (dabei Zellen möglichst atraumatisch behandeln und keine Zellen mit absaugen)

- Neues, zuvor im Wasserbad auf $37^{\circ} \mathrm{C}$ vorgewärmtes, Medium in Kulturgefäß geben

Der Zeitabstand zwischen einem Mediumwechsel hängt vom Medium und seinen Inhaltsstoffen einerseits, aber auch von der kultivierten Zelllinie ab. Die $\mathrm{zu}$ verwendenden Volumina für Medienwechsel und Subkultivierung (2.2.1.3) zeigt die folgende Tabelle:

\begin{tabular}{|l|l|l|}
\hline Kulturgefäßgröße $\left[\mathrm{cm}^{2}\right]$ & Medium/PBS Volumen $[\mathrm{ml}]$ & $0,25 \%$ Trypsin-EDTA Volumen [ml] \\
\hline $0,32(96 \mathrm{WP})$ & 0,1 & $0,01-0,02$ \\
\hline $3,8(12 \mathrm{WP})$ & 1 & $0,1-0,2$ \\
\hline $9,6(6 \mathrm{WP})$ & 3 & 0,5 \\
\hline 25 & 5 & 0,5 \\
\hline 75 & 10 & 1 \\
\hline 225 & 30 & 3 \\
\hline
\end{tabular}

Tabelle 5: Volumina für Medienwechsel und Subkultivierung

\subsubsection{Passagierung}

Bei zu hoher Zelldichte sinkt die Proliferationsrate stark ab und es besteht die Gefahr, dass die Kultur abstirbt. Grund ist einerseits die Konkurrenz um 
Nährstoffe und Wachstumsfaktoren, aber auch der dichte Zellkontakt an sich. Um die Zellen vor diesem Zustand zu bewahren, war es notwendig diese rechtzeitig (bei einer Konfluenz von ca. 70 bis $80 \%$ ) zu passagieren (nachfolgend auch als splitten oder subkultivieren bezeichnet). Im Folgenden eine kurze Zusammenfassung des hier verwendeten Verfahrens (die verwendeten Volumina stellt Tabelle 5 dar):

- Absaugen des alten Mediums

- Waschen mit vorgewärmter phosphatgepufferter Salzlösung (PBS)

- PBS absaugen

- Trypsin-EDTA-Lösung in Kulturgefäß geben, ca. 5 Minuten bei $37^{\circ} \mathrm{C}$ inkubieren und anschließend lichtmikroskopisch kontrollieren, ob die adhärenten Zellen erfolgreich abgelöst wurden

- Kulturgefäß mit gelösten Zellen und Trypsin-EDTA-Lösung mit Medium spülen, gesamtes Volumen in ausreichend großes Tube überführen und dieses 5 Minuten bei 800 rcf zentrifugieren

- Medium-Trypsin-EDTA-Gemisch absaugen

- Zellpellet mit neuem Medium suspendieren, entsprechend der Anfangs mikroskopisch festgestellten Konfluenz zwischen 1/3 und 1/15 teilen, den Zellanteil in ein Kulturgefäß überführen und dieses schließlich der Größe entsprechend mit Medium auffüllen

Trypsin ist eine Endopeptidase. Diese löst enzymatisch die Adhärenz zwischen Zellen und Kulturgefäß. Es galt darauf zu achten, dass die Zellen nicht wesentlich länger als nötig zum Lösen vom Untergrund mit diesem Enzym in Kontakt blieben, da andernfalls eine irreversible Schädigung der Kultur die Folge gewesen wäre. Wurden in absehbarer Zeit mehrere Zellen der Kultur benötigt, bestand die Möglichkeit, das Zellpellet je nach Verdünnung in mehrere Kulturgefäße aufzuteilen, wobei ein Gefäß für maximal 3 Passagen verwendet wurde. 


\subsubsection{Bestimmung der Zellzahl}

Für bestimmte Versuche bestand die Notwendigkeit der definierten Verwendung einer bestimmten Zellzahl. Hierzu wurden die Zellen mit Hilfe einer Neubauer-Zählkammer gezählt. Zunächst wurden die Zellen wie unter 2.2.1.3 beschrieben mit Hilfe der Trypsin-EDTA-Lösung gelöst, zentrifugiert und schließlich wieder in neuem Medium suspensiert. Die NeubauerZählkammer besteht aus zwei Kammerfenstern, diese enthalten unter anderem jeweils vier Leukozytenzählfelder. Es wurden $100 \mu \mathrm{l}$ der Zellsuspension mit $900 \mu \mathrm{l}$ Trypanblau vermischt und davon anschließend jeweils $10 \mu \mathrm{l}$ in beide Kammerfenster pipettiert und lichtmikroskopisch ausgezählt. Das arithmetische Mittel der acht Leukozytenfelder multipliziert mit dem Faktor $10^{5}$ ergab die Zellzahl pro Milliliter.

\subsubsection{Stabile Transfektion von miRNAs durch Elektroporation}

Die Transfektion der Zelllinien mit microRNAs erfolgte nach dem Protokoll zur Nukleofektion mittels Cell Line Nucleofector TM Kit V (Amaxa Biosystems). Bei dieser Methode wird die Zellmembran durch Spannungspulse für RNA durchgängig gemacht. Die Zellmembran fungiert als Isolierung des elektrisch leitfähigen Zytoplasmas. Elektrischer Strom kann erst durch die Zelle fließen, wenn Poren in der Membran entstanden sind. Durch die angelegte transmembrane Spannung kommt es für einige Sekunden bis Minuten zur transienten Permeabilität durch lokale Destruktion der Membranintegrität. Da es nicht jede Zelle schafft, die entstandenen Poren wieder zu schließend und die eigene Membran wieder zu reorganisieren, sterben bei diesem Vorgang auch einige Zellen ab. Dies wurde jedoch unter Berücksichtigung des Transfektionserfolgs in Kauf genommen und für den Versuch eine entsprechend ausreichende Zellzahl verwendet. Pro $5 \mu \mathrm{lu}$ transfizierende microRNA-Suspension wurden $2 \times 10^{6}$ Zellen verwendet. Die Durchführung aller Teilschritte erfolgte unter RNase-freien Bedingungen. Außerdem wurden zum Vergleich auch Zellen mit einer nicht genregulatorisch aktiven siRNA 
transfiziert (siNeg). Nach der Transfektion wurden die Zellen für nachfolgende Versuche in eine neue Kulturschale (6-Well-Plate) überführt und unter Verwendung von RPMI-Medium inkubiert.

\subsubsection{Colony-Forming-Unit-Culture-Assay (CFU-Assay)/ Zellbestrahlung}

72 Stunden nach der Transfektion wurden die Zellen für einen CFU-Assay gesetzt. Hierzu wurden zunächst, wie unter 2.2.1.4 beschrieben, Zellen gezählt, um schließlich die einzelnen Wells mit einer definierten Anzahl von Zellen zu versehen. Im weiteren Verlauf erhielten diese eine Radio- bzw. Radiochemotherapie (RT bzw. RCT mit 5-Fluoruracil). Die nachfolgende Abbildung gibt ein schematisches Beispiel bezüglich der Besetzung der 6Well-Plates:

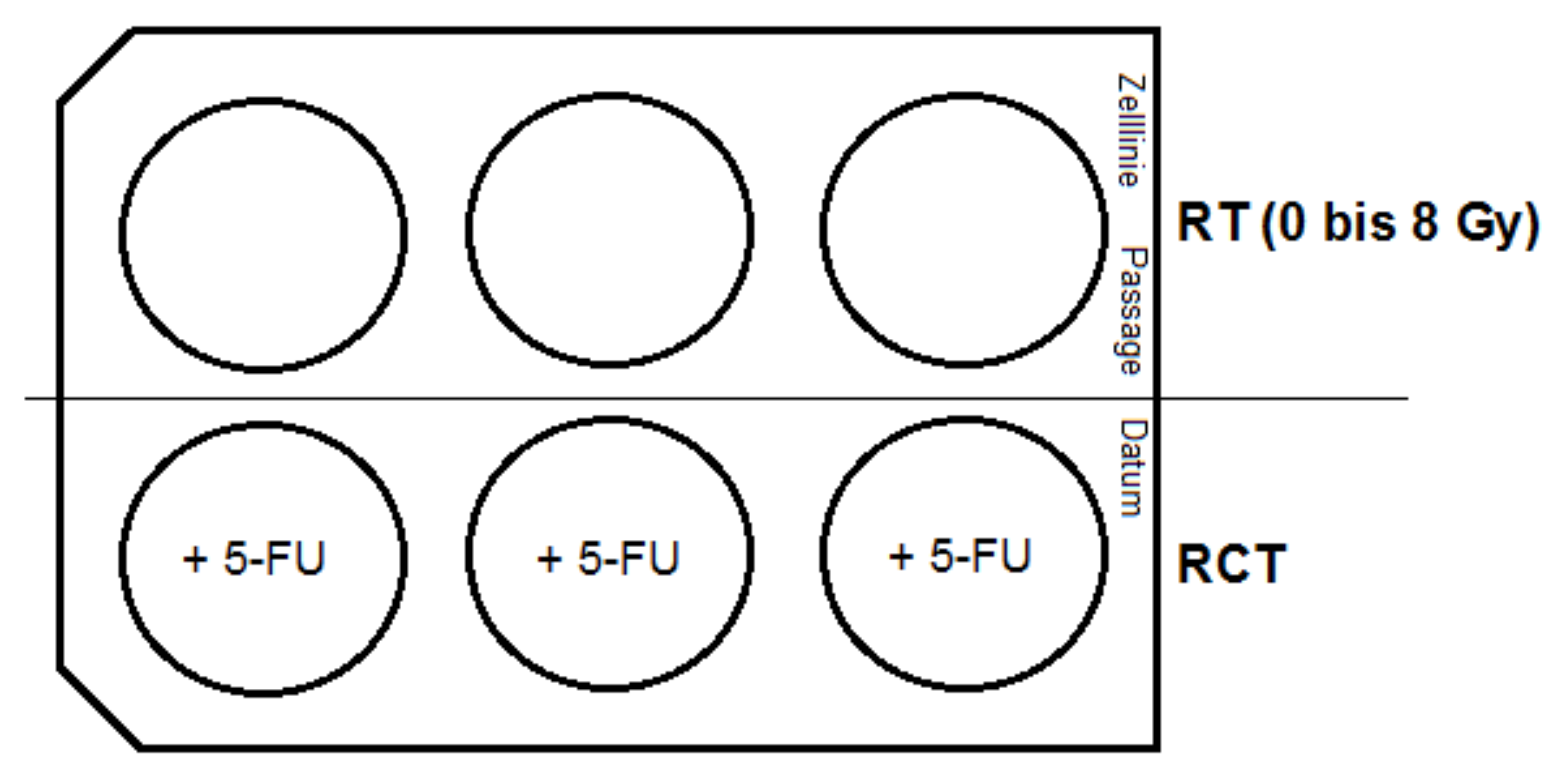

Abbildung 9: Besetzung der 6-Well-Plates für CFU-Assay und Bestrahlungsversuche (eigene Abbildung)

Das 5-Fluoruracil wurde 9 Stunden nach dem Setzen der Zellen in einer Konzentration von $3 \mu \mathrm{M}$ pro Well hinzugefügt. Es blieb für 24 Stunden in der Kulturschale und wurde dann durch einen Mediumwechsel wieder entfernt. Alle Versuchsreihen wurden als biologische Replikate $n=3$ (drei verschiedene 
Tage, drei verschiedene Passagen) durchgeführt. Die Anzahl der Zellen in den jeweiligen Wells richtete sich nach der Strahlendosis:

\begin{tabular}{|l|l|}
\hline $\begin{array}{l}\text { Strahlendosis } \\
{[\text { Gy }]}\end{array}$ & $\begin{array}{l}\text { Anzahl Zellen } \\
\text { pro Well }\end{array}$ \\
\hline 0 & 250 \\
\hline 1 & 250 \\
\hline 2 & 250 \\
\hline 4 & 500 \\
\hline 6 & 750 \\
\hline 8 & 1000 \\
\hline
\end{tabular}

Tabelle 6: Zellen pro Well in Abhängigkeit von der Strahlendosis

Insgesamt 96 Stunden nach Transfektion erfolgte schließlich die Bestrahlung der Zellen.

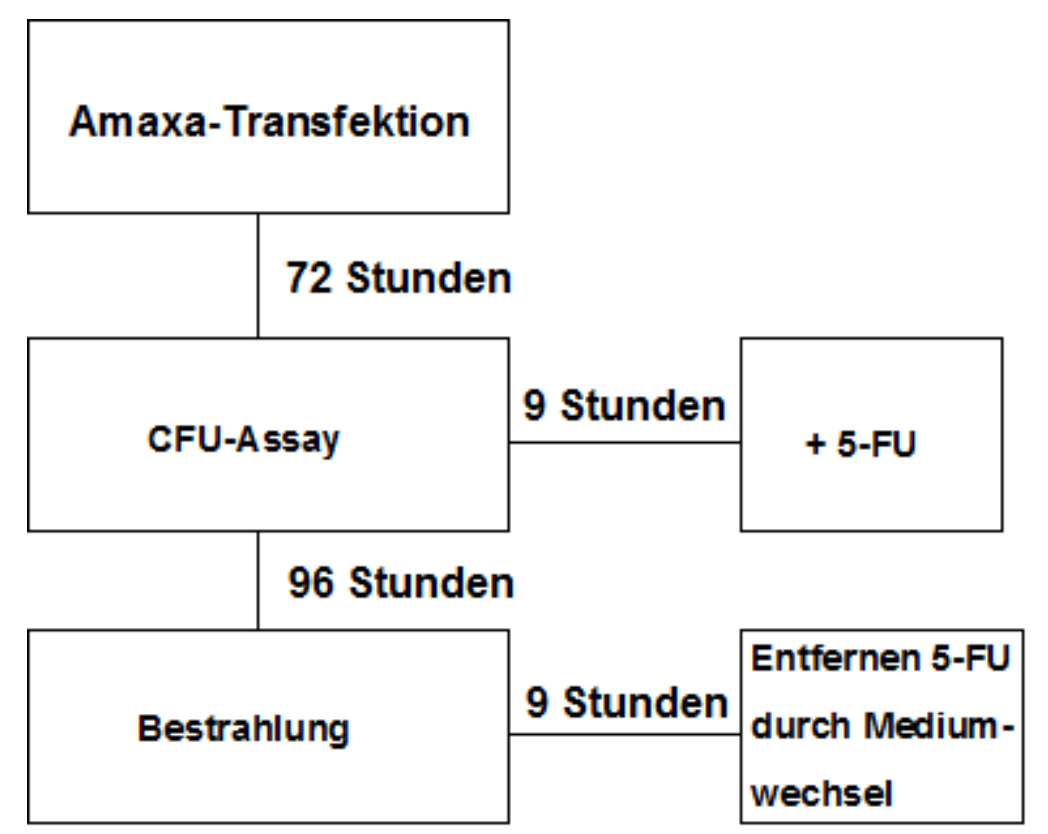

Abbildung 10: Schematische Darstellung des Versuchsablaufs (eigene Abbildung)

Ca. 8 Tage nach der Bestrahlung konnte jedem Well $1 \mathrm{ml}$ Medium zugefügt werden. Bei Versuchen mit der Zelllinie SW480 wurde 10 Tage nach Bestrahlung der CFU-Assay gestoppt. Hierzu wurde den Kulturgefäßen das 
Medium entzogen und die Zellen in 70\% Ethanol fixiert. Anschließend konnten die Kolonien in den jeweiligen Wells nach vorangegangener Färbung mit Kristallviolett lichtmikroskopisch gezählt werden. Eine Kolonie bestand dann, wenn diese 50 oder mehr Zellen umfasste.

\subsubsection{Zellpräparation und RNA-Isolation}

\subsubsection{Zellpräparation}

Für den Vorversuch lag Patientenmaterial von insgesamt 14 Patienten zur Untersuchung vor. Jeweils 7 Patienten erhielten als Vorbehandlung 5-FU oder Oxaliplatin + 5-FU. Beide Regimes wurden von einer Radiotherapie begleitet. Bereits vor Beginn der neoadjuvanten Therapie wurden endoskopisch Biopsien entnommen. Nach Abschluss der Vorbehandlung und erfolgter Resektion konnte auch aus dem Resektat Tumorgewebe gewonnen werden. Sowohl das Gewebe aus der prätherapeutischen Biopsie, als auch das aus dem Resektat wurde mit Paraffin fixiert. Anschließend konnten daraus Schnitte mit einer Dicke von $8-10 \mu \mathrm{m}$ angefertigt werden. Ziel war es, aus diesen Schnitten möglichst nur die Tumorzellen mikroskopisch heraus zu präparieren. Hierzu musste das Gewebe zunächst durch verschiedene Waschschritte in Glasküvetten vom Paraffin befreit und schließlich mit Hämalaun angefärbt werden. Die Schnitte wurden daraufhin direkt mikroskopiert und mikrodisseziert.

Die angewendete Vorgehensweise zeigt folgende Abbildung:

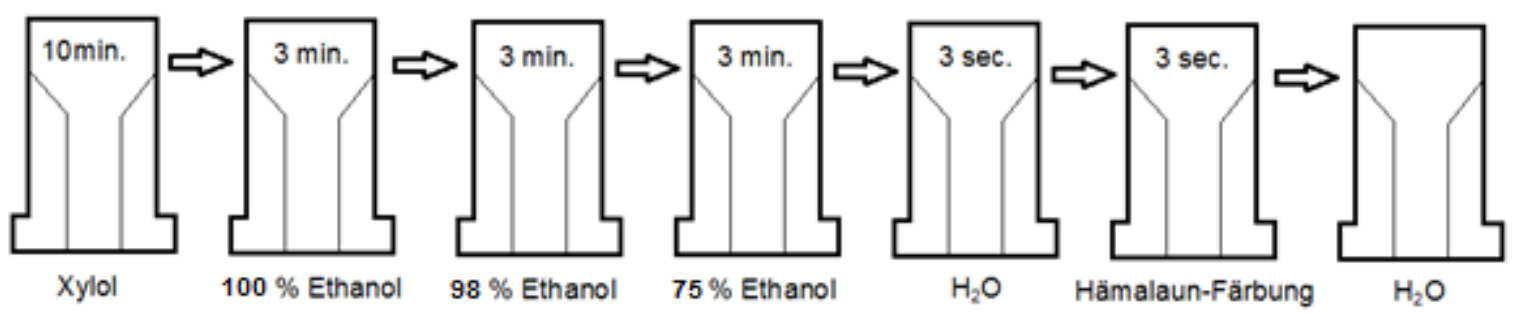




\subsubsection{RNA-Isolation}

Die Isolation von microRNA aus den Tumorzellen erfolgte mit Hilfe des AllPrep ${ }^{\circledR}$ DNA/RNA-Kits der Firma Qiagen.

Hierzu wurden zunächst die mikroskopisch präparierten Zellen in $1 \mathrm{ml}$ Ethanol gelöst um etwaige Paraffinrückstände zu extrahieren und das Reaktionsgefäß zentrifugiert. Der Überstand wurde entnommen und verworfen. Anschließend wurde das Zellpellet in Proteinase-K-Verdauungspuffer gelöst und schließlich zur Lyse der Zellen Proteinase $\mathrm{K}$ hinzugefügt. Nach weiteren Inkubations- und Zentrifugationsschritten konnte der Überstand in ein neues 2-mlReaktionsgefäß überführt werden. Dieser Überstand wurde anschließend bei $80{ }^{\circ} \mathrm{C}$ für 15 min. inkubiert. Nach Hinzufügen eines weiteren Puffers zur Anpassung der Bindungsproteine und 96-100\%igem Ethanol konnte die Gesamtlösung zur RNA-Gewinnung weiter aufgereinigt werden. Eine silikatische Gelmembran in den verwendeten „RNeasy-Säulen“ bindet die RNA in Anwesenheit von Ethanol. Daher wurde die gesamte Lösung nacheinander durch Zentrifugation mit der Membran in Kontakt gebracht. Die Membran enthielt daraufhin die RNA und der Durchfluss konnte verworfen werden. Nach weiteren Reinigungs- und Zentrifugationsschritten mussten noch DNARückstände von der Membran entfernt werden. Hierzu wurde eine DNase I enthaltende Lösung angesetzt, direkt auf die Membran aufgetragen und für 15 min. bei Raumtemperatur inkubiert. Nach Zugabe eines weiteren Puffers und anschließender Zentrifugation wurde die Lösung mit der ganzen Membran in Kontakt gebracht. Abschließend konnte die RNA nach einem weiteren Reinigungs- und Zentrifugationsschritt eluiert werden. Hierzu wurde RNasefreies Wasser direkt auf die Gelmembran pipettiert, 5 min. inkubiert und schließlich $2 \mathrm{~min}$ bei voller Geschwindigkeit zentrifugiert. Der Durchfluss enthielt die in Wasser gelöste RNA. Um die RNA-Konzentration möglichst hoch zu halten, wurde mit $14 \mu \mathrm{l}$ die geringstmögliche Menge Wasser für die Eluierung verwendet. 


\subsubsection{RNA-Konzentrationsmessung}

Die Konzentration an RNA konnte unter Verwendung eines „NanoDrop $1000^{\Theta_{-}}$ Spectrophotometers" ermittelt werden.

Die Extinktion ist nach dem Lambert-Beer'schen Gesetz proportional zum molaren Extinktionskoeffizienten (40 für RNA), zu der Konzentration des gelösten Stoffes und der durchstrahlten Schichtdicke. Dies erlaubt einen direkten Rückschluss auf die Konzentration an RNA in der gemessenen Probe. Das Absorptionsmaximum von Nukleinsäuren liegt bei $260 \mathrm{~nm}$. Für Proteine beträgt dieser Wert $280 \mathrm{~nm}$. Der Quotient der Extinktionen bei diesen beiden Werten ist ein Maß für die Verunreinigung der Proben mit Proteinen und sollte zwischen 1,8 und 2,0 liegen.

\subsubsection{Reverse Transkription}

Ribonukleinsäuren weisen hinsichtlich der PCR zwei wesentliche Probleme auf. Zum einen werden sie von der Taq-Polymerase schlecht als Matrize erkannt und zum anderen werden sie von RNasen leichter degradiert, da diese ubiquitär häufiger vorkommen als DNasen. Aus diesem Grund war es für die Versuche sinnvoll, die RNA in stabilere, komplementäre DNA, die so genannte cDNA, umzuschreiben.

Für die reverse Transkription wurde das RT-II-Kit ${ }^{\circledR}$ der Firma Qiagen verwendet. Das zugehörige Protokoll wird nachfolgend kurz erläutert:

Zunächst wurde die gewünschte Menge an RNA (500 ng bzw. 200 ng) durch Zugabe von sterilem, RNase- und DNase-freiem Wasser auf ein Gesamtvolumen von $6 \mu \mathrm{l}$ verdünnt. Anschließend wurde ein für die Reaktion notwendiger Mastermix erstellt. Die Bestandteile sind in dem RT-II-Kit ${ }^{\circledR}$ enthalten und werden in nachfolgender Tabelle dargestellt: 


\begin{tabular}{|l|l|}
\hline Bestandteil & Volumen pro Probe in [ $\mu \mathrm{l}]$ \\
\hline 5-fach miScript HiSpec-Puffer & 2 \\
\hline 10-fach Nucleic-Mix & 1 \\
\hline miScript Reverse-Transkriptase-Mix II & 1 \\
\hline Gesamtvolumen & 4 \\
\hline
\end{tabular}

Tabelle 7: Bestandteile des Mastermix aus dem RT-II-Kit® (Qiagen)

Die RNA und der Mastermix konnten dann in einem 0,2-ml-Tube zu einem Gesamtvolumen von 10 $1 /$ /Probe zusammengeführt und zunächst für $60 \mathrm{~min}$. bei $37^{\circ} \mathrm{C}$ inkubiert werden. Anschließend wurde die Temperatur auf $95{ }^{\circ} \mathrm{C}$ erhöht und für weitere 5 min. inkubiert. In diesem Schritt wird das Enzym Reverse-Transkriptase denaturiert und die Reaktion somit gestoppt. Abschließend wurde den Reaktionsgefäßen steriles, RNase- und DNase-freies Wasser zugefügt, bis die RNA-Konzentration der einzelnen Proben einen rechnerischen Wert von $10 \mathrm{ng} / \mu \mathrm{l}$ erreichte. Dieser Schritt sorgte für eine einfachere Handhabung beim PCR-Pipettieren.

\subsubsection{Semiquantitative Real-Time-PCR (qRT-PCR)}

Die qRT-PCR wurde mit dem miScript SYBR® Green PCR-Kit und den Anweisungen des entsprechenden Handbuches durchgeführt (miScript PCR System Handbook, Qiagen Oktober 2011).

Mit Hilfe dieser Methode ist es möglich, eine quantitative Einschätzung der Genexpression vorzunehmen (Pfaffl 2004). Ziel in diesem Projekt war die Bestimmung der Expression bestimmter microRNAs, welche aus unter 2.2.6 beschriebenen Gründen zuvor in komplementäre cDNA umgeschrieben wurden.

Die Polymerasekettenreaktion verläuft in Zyklen. Ein Zyklus besteht aus drei Phasen und wird etwa 30-40-mal wiederholt. Den Beginn stell die 
Denaturierungsphase dar. Die cDNA wird auf $94^{\circ} \mathrm{C}$ erhitzt, dadurch trennen sich die DNA-Doppelstränge auf. In der darauf folgenden Annealing-Phase wird die Temperatur auf $55^{\circ} \mathrm{C}$ gesenkt, woraufhin die Primer sich an die DNA anlagern können. Den letzten Schritt in diesem Zyklus bildet die Elongationsphase. Hier wird die Temperatur auf $70{ }^{\circ} \mathrm{C}$ erhöht, damit das Kernenzym der PCR, die Taq-Polymerase, neue DNA-Doppelstränge anhand der cDNA-Matrize synthetisieren kann. Am Ende jeder Elongationsphase interkaliert der Fluoreszenzfarbstoff SYBR Green® mit den entstandenen DNA-Doppelsträngen und emittiert daraufhin nach erfolgter Anregung durch einen Laser Licht der Wellenlänge $520 \mathrm{~nm}$, dessen Intensität dann gemessen werden kann und einen Rückschluss auf die Menge erlaubt. Wenn das Fluoreszenzsignal das Hintergrundleuchten des Farbstoffes nach einer bestimmten Anzahl von Zyklen übertrifft, steigt dieses exponentiell an. Den Wert dieser Zyklusanzahl nennt man Ct-Wert (Cycle-Threshold-Wert), beziehungsweise Quantification Cycle $(\mathrm{Cq})$. Darüber hinaus konnte durch die gleichzeitige Messung von Referenzgenen (sog. „Housekeeper"-Genen) eine Normalisierung und die Berechnung der relativen Expression der zu bestimmenden Gene gewährleistet werden. Anhand der Ct-Werte und der Formel $2^{(\Delta C t \text { Probe } 1)-(\Delta C t \text { Probe } 2)}$ errechnet sich der Fold Change. Dieser erlaubt dann den unmittelbaren Vergleich korrespondierender Proben. Die PCR wurde auf einem Termocycler der Firma Bio-Rad (Model CFX384) mit dem miScript SYBR $®$ Green PCR-Kit nach Angaben des Herstellers in Triplikaten mit einer optimierten Konzentration der genspezifischen Primer durchgeführt. Die nachfolgende Tabelle fast das gewählte Temperaturprogramm und die entsprechenden Zeiten eines Zyklus zusammen: 


\begin{tabular}{|l|l|l|l|}
\hline $\begin{array}{l}\text { Initiale Aktivierung } \\
\text { der PCR }\end{array}$ & $95^{\circ} \mathrm{C}$ & $15 \mathrm{~min}$. & $\begin{array}{l}\text { Die Hot-Star-Taq- } \\
\text { Polymerase wird durch } \\
\text { diesen Schritt aktiviert }\end{array}$ \\
\hline Denaturierungsphase & $94^{\circ} \mathrm{C}$ & $15 \mathrm{sec}$. & \\
\hline Annealing-Phase & $55^{\circ} \mathrm{C}$ & $30 \mathrm{sec}$. & $\begin{array}{l}\text { Fluoreszenzmessung } \\
\text { nach Abschluss der } \\
\text { Phase }\end{array}$ \\
\hline Elongationsphase & $70^{\circ} \mathrm{C}$ & $30 \mathrm{sec}$. & \\
\hline
\end{tabular}

Tabelle 8: Temperaturprogramm des Bio-Rad CFX384-Termocyclers

Die PCR-Ansätze wurden in 384-Well-Platten pipettiert. Die einzelnen Komponenten und ihre Volumina zeigt Tabelle 9:

\begin{tabular}{|l|l|}
\hline Komponente & Volumen in $[\mu \mathrm{l}]$ \\
\hline 2-fach SYBR $\circledast$ Green PCR-Mastermix & 5 \\
\hline 10-fach miScript Universal-Primer & 1 \\
\hline 10-fach miScript Primer Assay & 1 \\
\hline RNase-freies Wasser & variabel \\
\hline cDNA-Vorlage & $\leq 1$ \\
\hline Gesamtvolumen & 10 \\
\hline Tabelle 9: Komponenten und Volumina für qRT-PCR
\end{tabular}

Für das Pipettieren aller PCR-Proben des Vorversuchs wurden insgesamt vier 384-Well-Platten benötigt. Ein exemplarisches Pipettierschema zeigt Abbildung 12. 


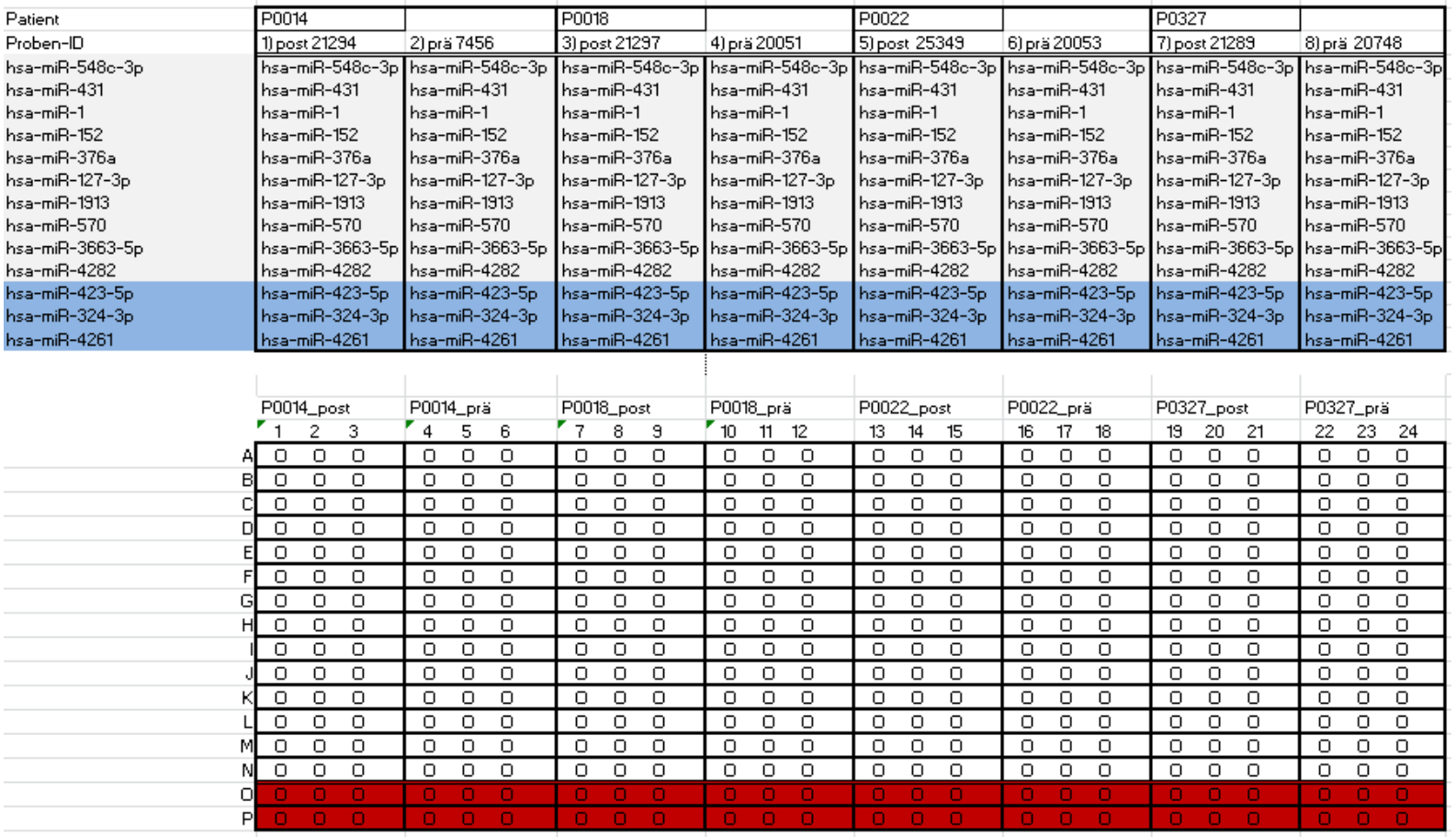

Abbildung 12: Beispiel Pipettierschema QPCR 1 (grau unterlegt: Primer/Targets; blau unterlegt: „Housekeeper“, Durchführung erfolgte jeweils als Triplikat)

Nach Vorliegen der Ergebnisse des Vorversuchs wurden anhand der FoldChange-Daten diejenigen microRNAs ausgewählt, welche in der posttherapeutischen Probe (Resektat) bei nahezu allen Patienten deutlich höher exprimiert waren. Diese wurden dann anhand eines unabhängigen Kollektivs mit korrespondierenden prä- und posttherapeutischen Proben validiert. Die Normalisierung und die Berechnung der relativen Expression der zu bestimmenden Gene wurden durch die gleichen „Housekeeper"-Gene wie im Vorversuch gewährleistet. Die nachfolgende Abbildung zeigt exemplarisch die Belegung einer 384-Well-Platte für die Validierungs-QPCR: 


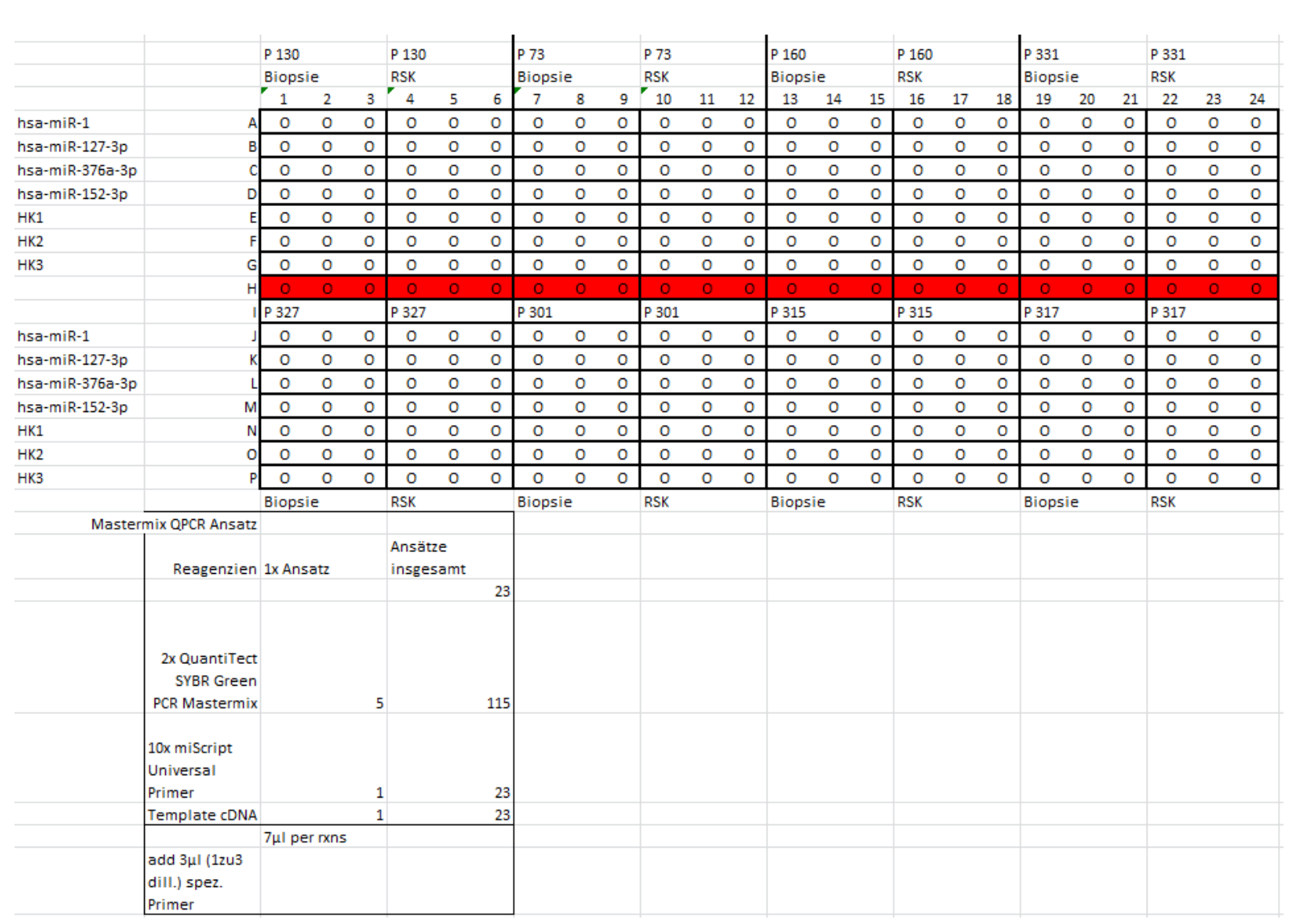

Abbildung 13: Beispiel Pipettierschema QPCR 2 (RSK=Resektat, HK= Housekeeper)

\subsubsection{Micro-Array-Analysen}

Bei Micro-Array-Analysen werden zu untersuchende Proben (hier aus RNA umgeschriebene cDNA) auf Objektträger gegeben, welche zuvor mit spezifischen Oligonukleotiden bestückt wurden. Anschließend werden die Proben hybridisiert. Nach weiteren Waschschritten, in denen nicht gebundene cDNA vom Objektträger entfernt wird, kann das Fluoreszenzsignal jeder Position des Micro-Arrays mittels eines Lasers ausgelesen werden. Die fertigen und normalisierten Werte werden üblicherweise logarithmisch dargestellt und können so miteinander verglichen werden. 


\section{Ergebnisse}

Ein bereits abgeschlossenes Projekt der klinischen Forschungsgruppe 179 beschäftigte sich mit Micro-Array-Analysen zur Expression aller bis dahin bekannten microRNAs im kolorektalen Karzinom. In diesem Versuch wurde die Expression der microRNAs in Tumorzellen vor neoadjuvanter Radiochemotherapie (aus der Biopsie) und nach der Operation (im Resektat) bestimmt und miteinander verglichen.

Die Array-Experimente sind nicht Bestandteil der vorliegenden Dissertation. Deren Ergebnisse jedoch waren Grundlage für die Auswahl der weiter zu untersuchenden microRNAs. Ausgewählt wurden jene microRNAs, bei denen der Differenzbetrag der Cq-Werte (Cq[Biopsie] - Cq[Resektat]) besonders hoch war. Also solche microRNAs, die im Resektat höher exprimiert waren als in der Biopsie.

Ziel dieser Arbeit war es, Teile der Ergebnisse der Array-Analysen per qRTPCR und anschließend ausgewählte microRNAs funktionell per Transfektion und Colony-Forming-Unit-Culture-Assay zu valideren. Hierzu wurde zunächst das Patientenmaterial von 14 Patienten untersucht. Das Material von sieben dieser Patienten fand bereits in den Array-Analysen Verwendung, sodass dieser Teil ein technisches Replikat darstellte. Die übrigen sieben Patienten bildeten bereits ein unabhängiges Kollektiv. Untersucht wurde aus Tumorzellen isolierte microRNA aus prätherapeutischen Biopsien und OPResektaten nach Radiochemotherapie, zunächst hinsichtlich von zehn Targets (siehe Abbildung 14).

Nach Auswertung dieses ersten Versuchs (QPCR 1) wurde die Anzahl der zu untersuchenden Targets (microRNAs) weiter eingegrenzt, und es galt, diese an einem unabhängigen Patientenkollektiv von 18 Patienten zu validieren (QPCR 2).

Im Anschluss daran folgte die funktionelle Validierung mittels Colony-FormingUnit-Culture-Assay. Die nachfolgende Abbildung fasst den Ablauf der Experimente schematisch zusammen: 


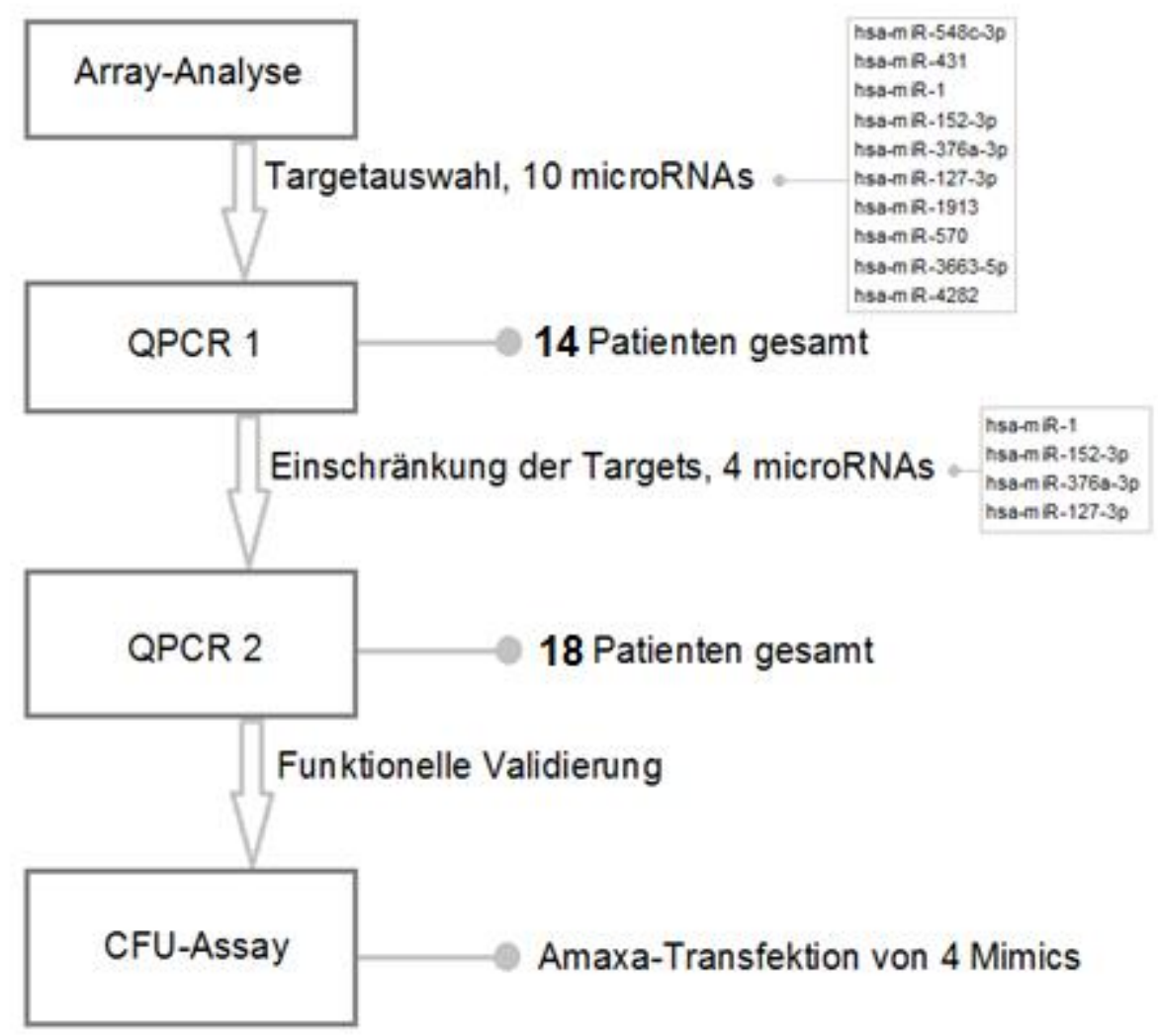

Abbildung 14: Schematischer Ablauf der Experimente (eigene Abbildung) 


\subsection{Auswertung QPCR 1}

Zunächst wurden 10 microRNAs, die aus den Array-Analysen eine deutlich höhere Expression im Resektat verglichen mit der Biopsie zeigten, mittels qPCR in einem Patientenkollektiv von 14 Patienten validiert (miR-1, -152-3p, 376a-3p, - 127-3p, -548c-3p, -431, -1913, - 570, -3663-5p und -4282). Dabei zeigten vier der zehn untersuchten microRNAs per qPCR eine höhere Expression im Resektat als in der Biopsie:

Bei miR-1, miR-127-3p und miR-152-3p war dies in 92,9 \% (13 von 14) und bei miR-376a-3p in 85,7 \% (12 von 14) der Fälle gegeben. Die übrigen sechs microRNAs miR-548c-3p, miR-431, miR-1913, miR-570, miR-3663-5p und miR-4282 zeigten ein eher inhomogenes Expressionsmuster. Auf der y-Achse der unten aufgeführten Diagramme (siehe Abbildung 15) ist der CqDifferenzbetrag aufgeführt (Cq[Biopsie] $-\mathrm{Cq}[$ Resektat]).

Der abgebildete Wert gibt den relativen Expressionsunterschied wieder. Ein direkter Rückschluss auf die absolute Konzentration ist hieraus nicht möglich (eine Differenz $[\Delta \mathrm{Cq}]$ von +1 entspricht beispielsweise einer Verdopplung, +2 einer Vervierfachung, usw.). 


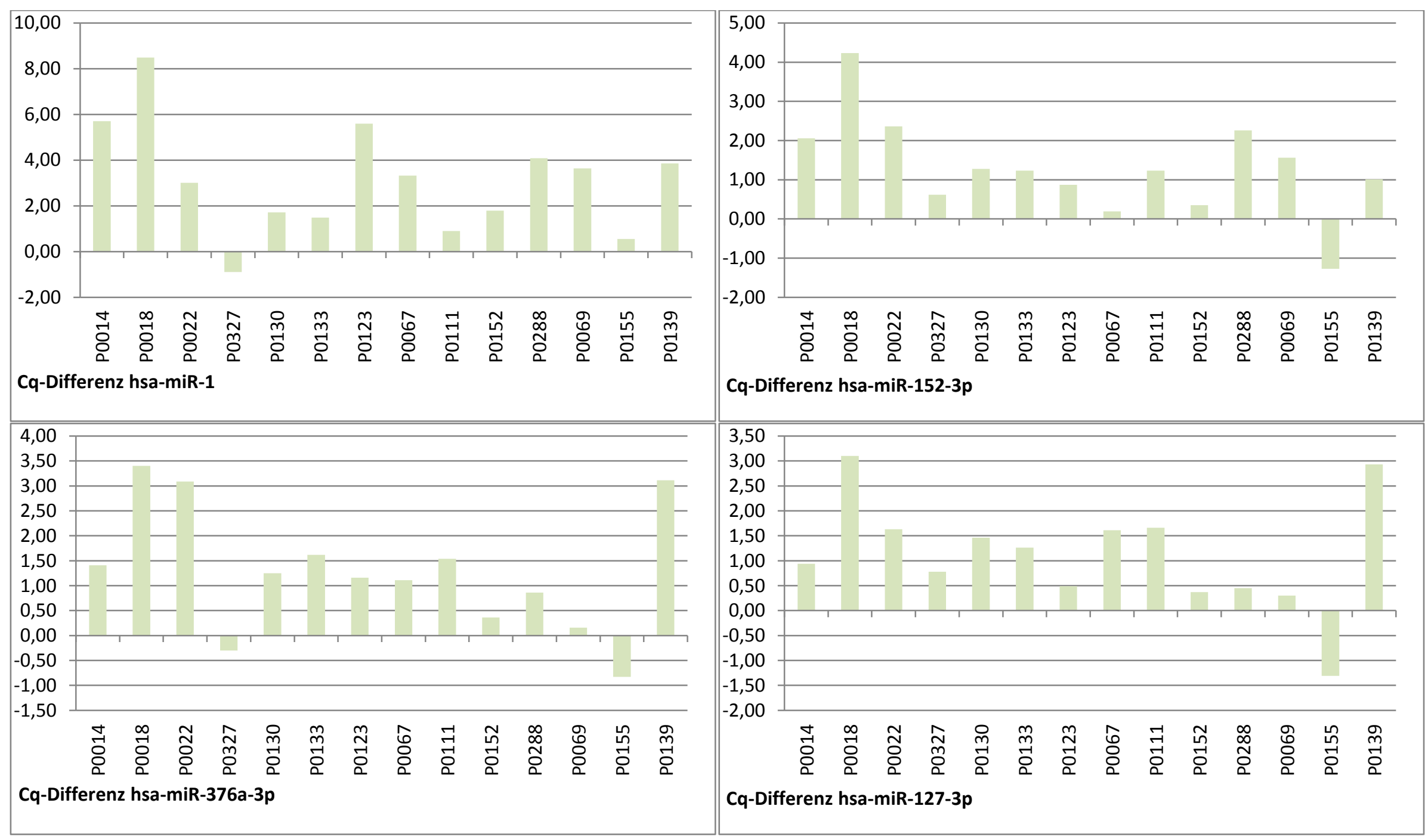

Abbildung 15: QPCR 1, Cq-Differenz (Cq-Wert[Biopsie] - Cq-Wert[Resektat]) der microRNAs miR-1, -152-3p, -376a-3p und -127-3p 


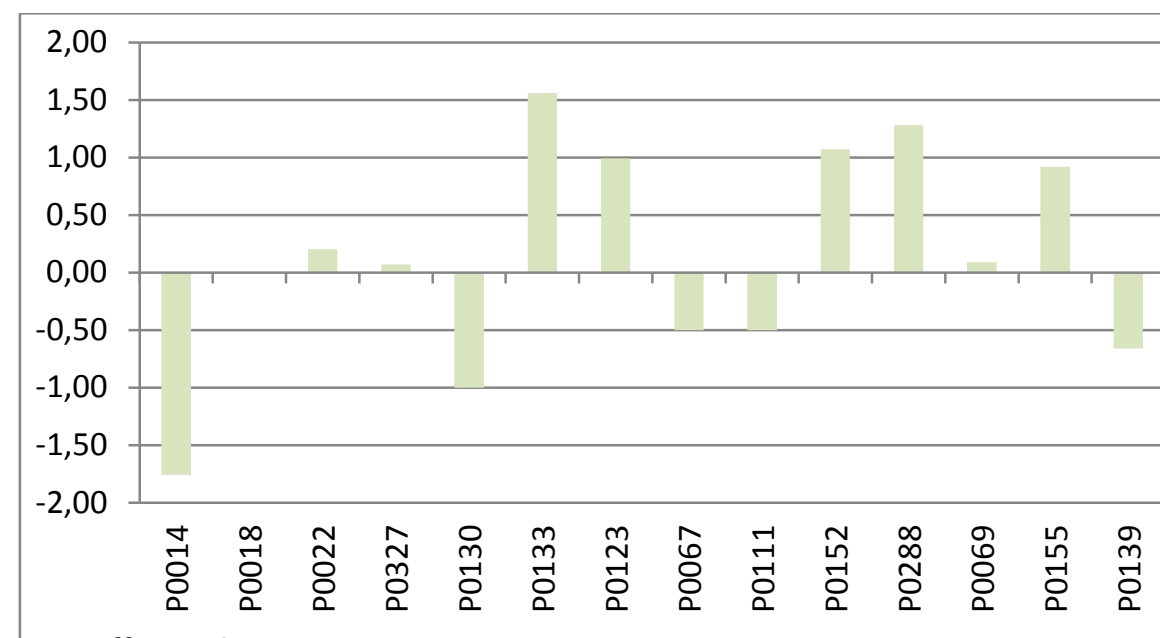

Cq-Differenz hsa-miR-548c-3p

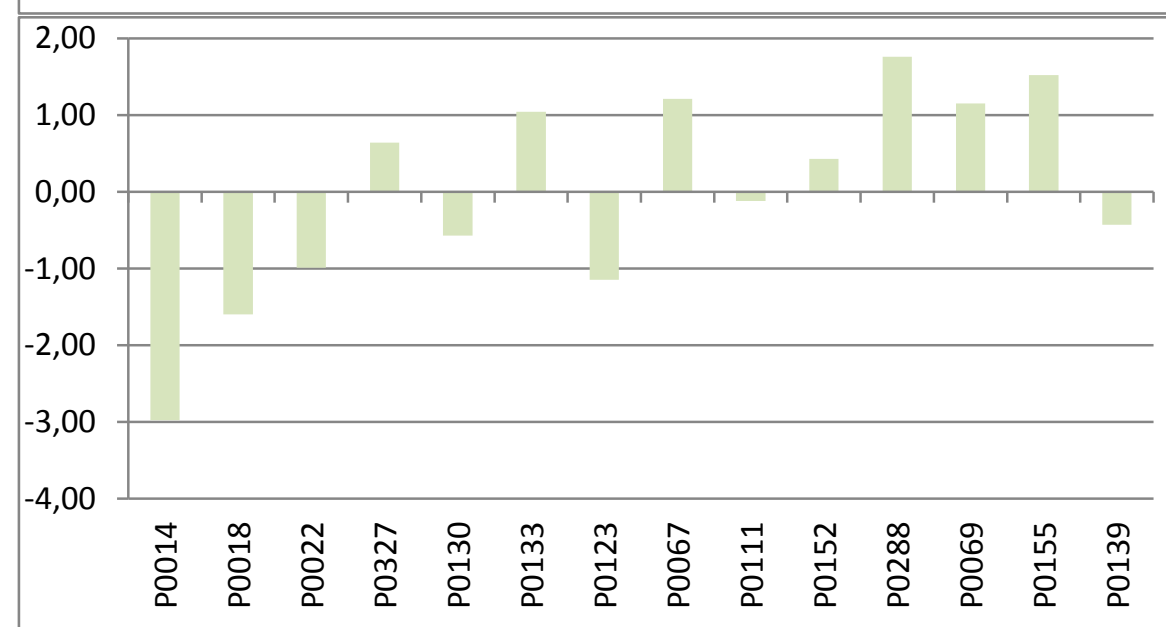

Cq-Differenz hsa-miR-1913

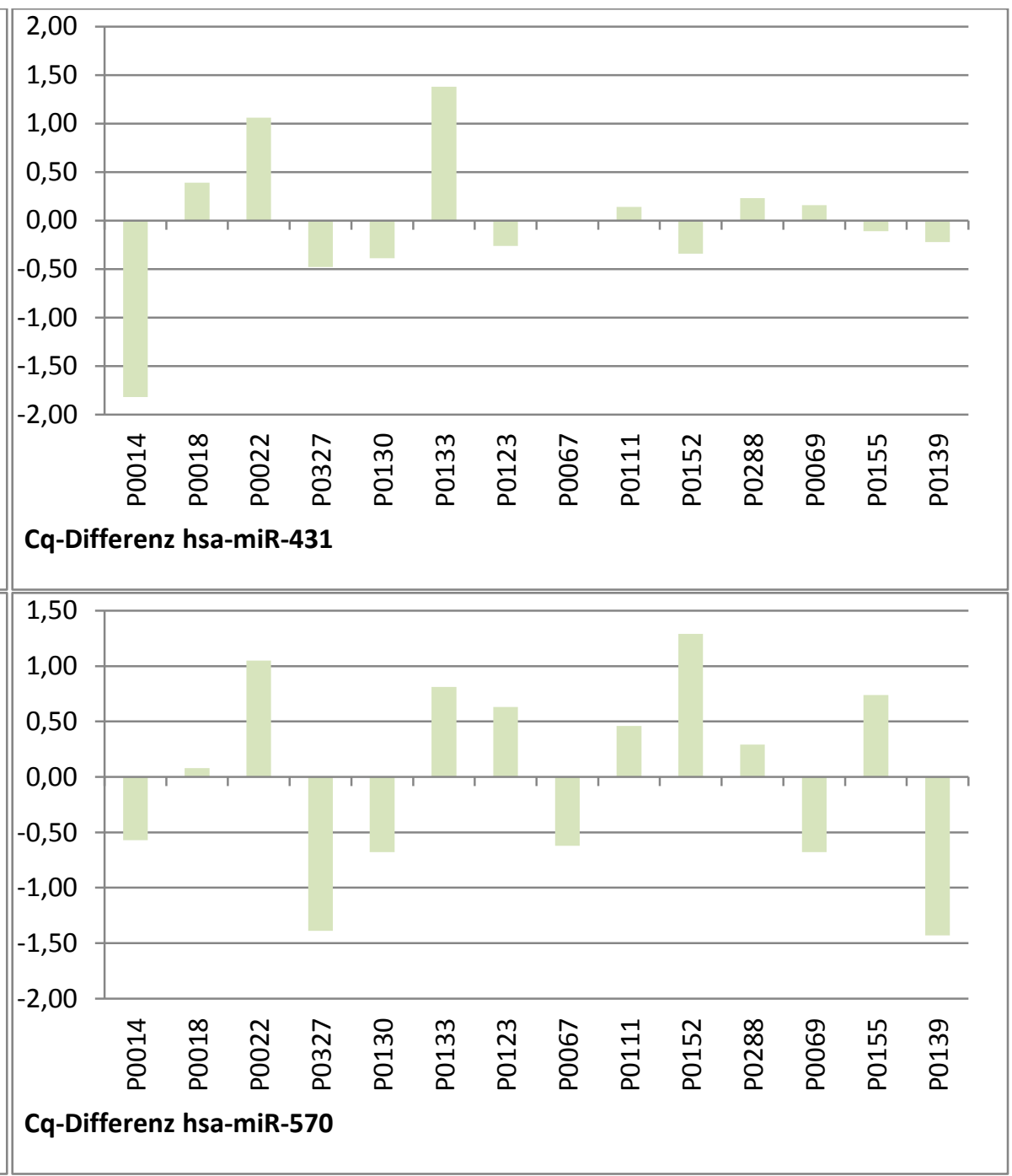

Abbildung 16: QPCR 1, Cq-Differenz (Cq-Wert[Biopsie] - Cq-Wert[Resektat]) der microRNAs miR-548c-3p, -431, -1913 und -570 


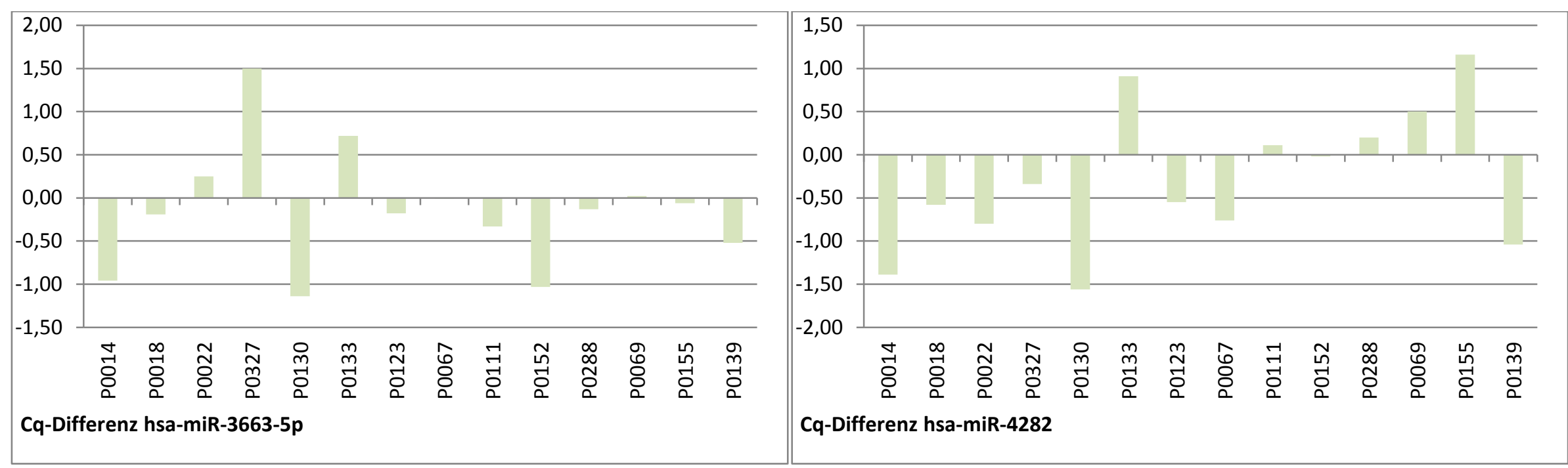

Abbildung 17: QPCR 1, Cq-Differenz (Cq-Wert[Biopsie] - Cq-Wert[Resektat]) der microRNAs miR-3663-5p und -4282 


\subsection{Auswertung QPCR 2}

Nach Abschluss der QPCR 1 wurde Material eines unabhängigen Patientenkollektivs rekrutiert und isoliert. Wie oben in der Ablaufbeschreibung der Experimente bereits erwähnt, wurde bei der QPCR 2 die Auswahl der zu untersuchenden microRNAs eingegrenzt. Weiter untersucht wurden die microRNAs miR-1, miR-127-3p, miR-152-3p und miR-376a-3p. Die übrigen sechs microRNAs wurden aufgrund des uneinheitlichen Expressionsmuster nicht weiter untersucht.

Die Werte aus diesem zweiten Versuch folgten überwiegend der Tendenz der Ergebnisse aus der QPCR 1. Hier war miR-1 in 66,7\% (12 von 18), miR-127$3 p$ in $88,9 \%$ (16 von 18), miR-376a-3p in 83,3 \% (15 von 18) und miR-152-3p ebenfalls in 83,3 \% (15 von 18) der Fälle im Resektat höher exprimiert, als in der prätherapeutischen Biopsie.

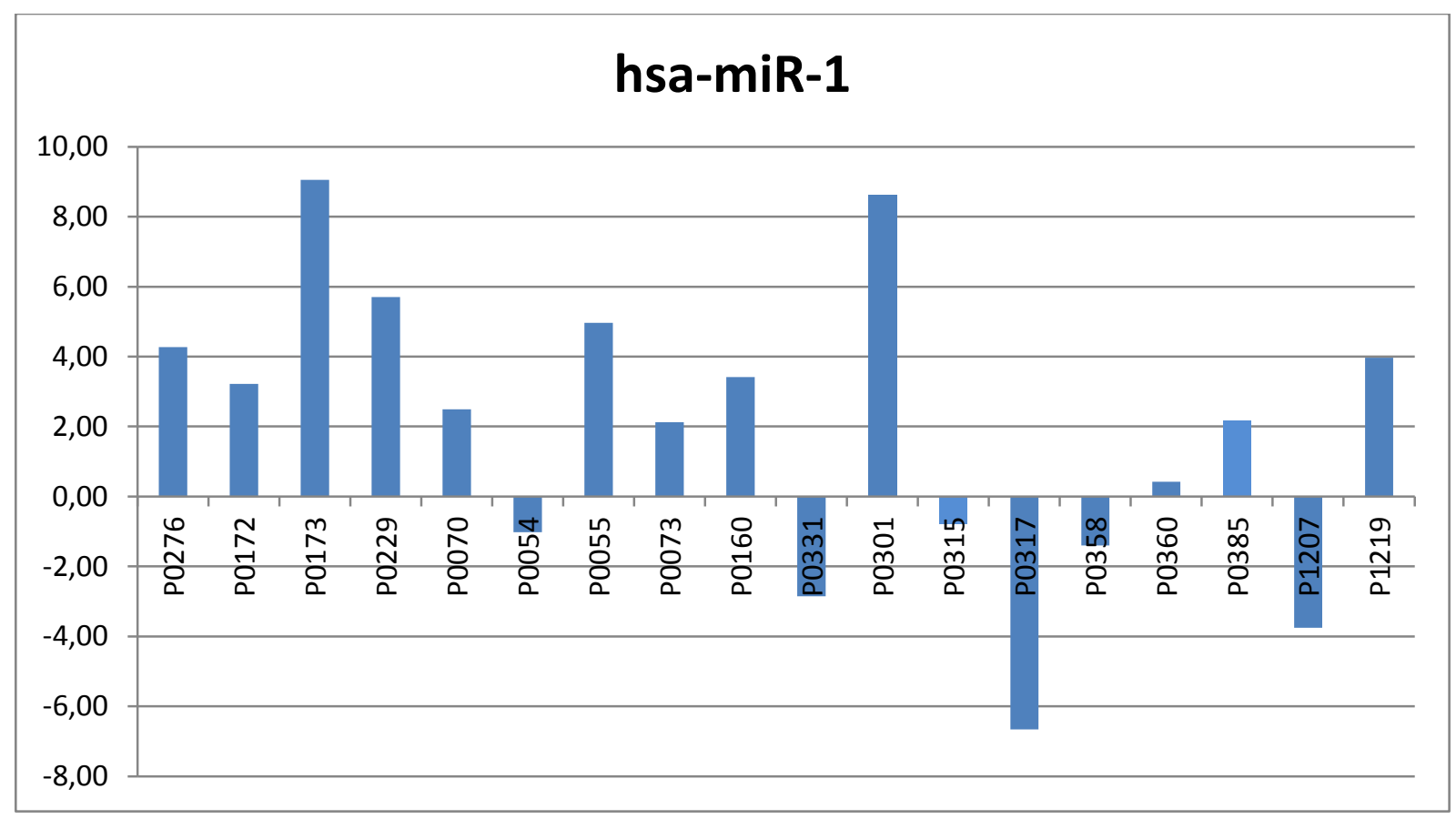

Abbildung 18: QPCR 2, Cq-Differenz (Cq-Wert[Biopsie] - Cq-Wert[Resektat]) von miR-1 


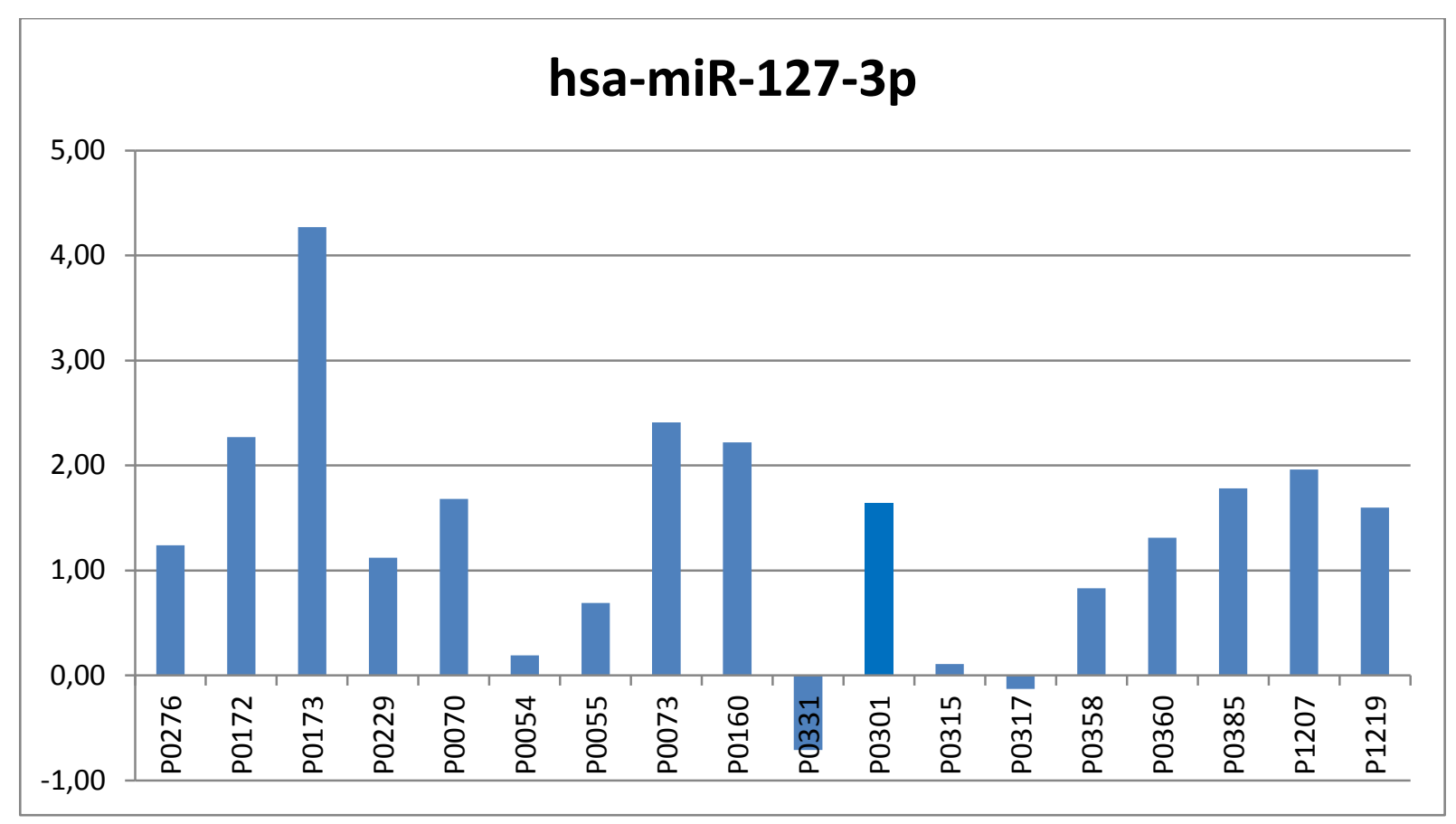

Abbildung 19: QPCR 2, Cq-Differenz (Cq-Wert[Biopsie] - Cq-Wert[Resektat]) von miR-127-3p

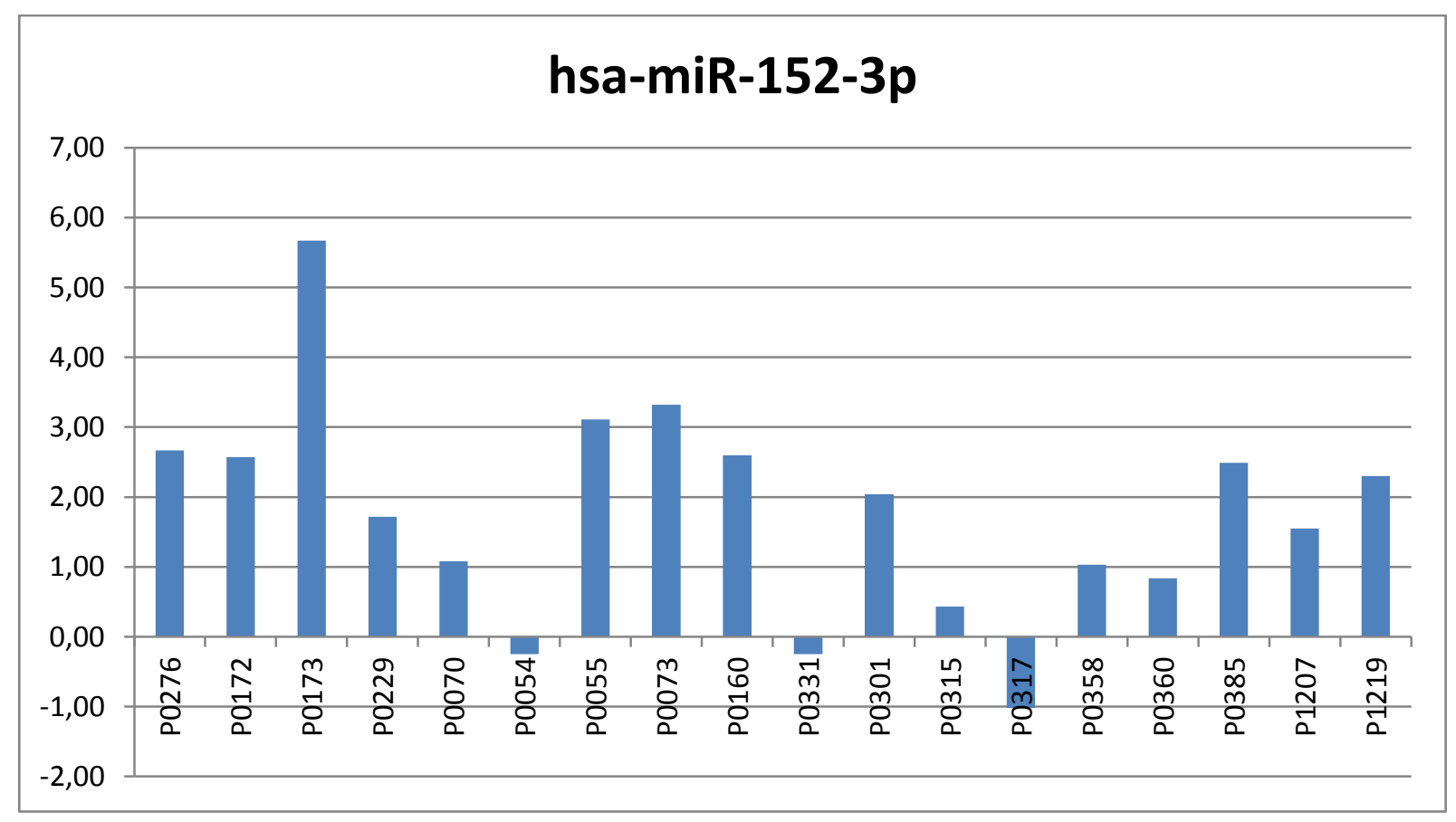

Abbildung 20: QPCR 2, Cq-Differenz (Cq-Wert[Biopsie] - Cq-Wert[Resektat]) von miR-152-3p 


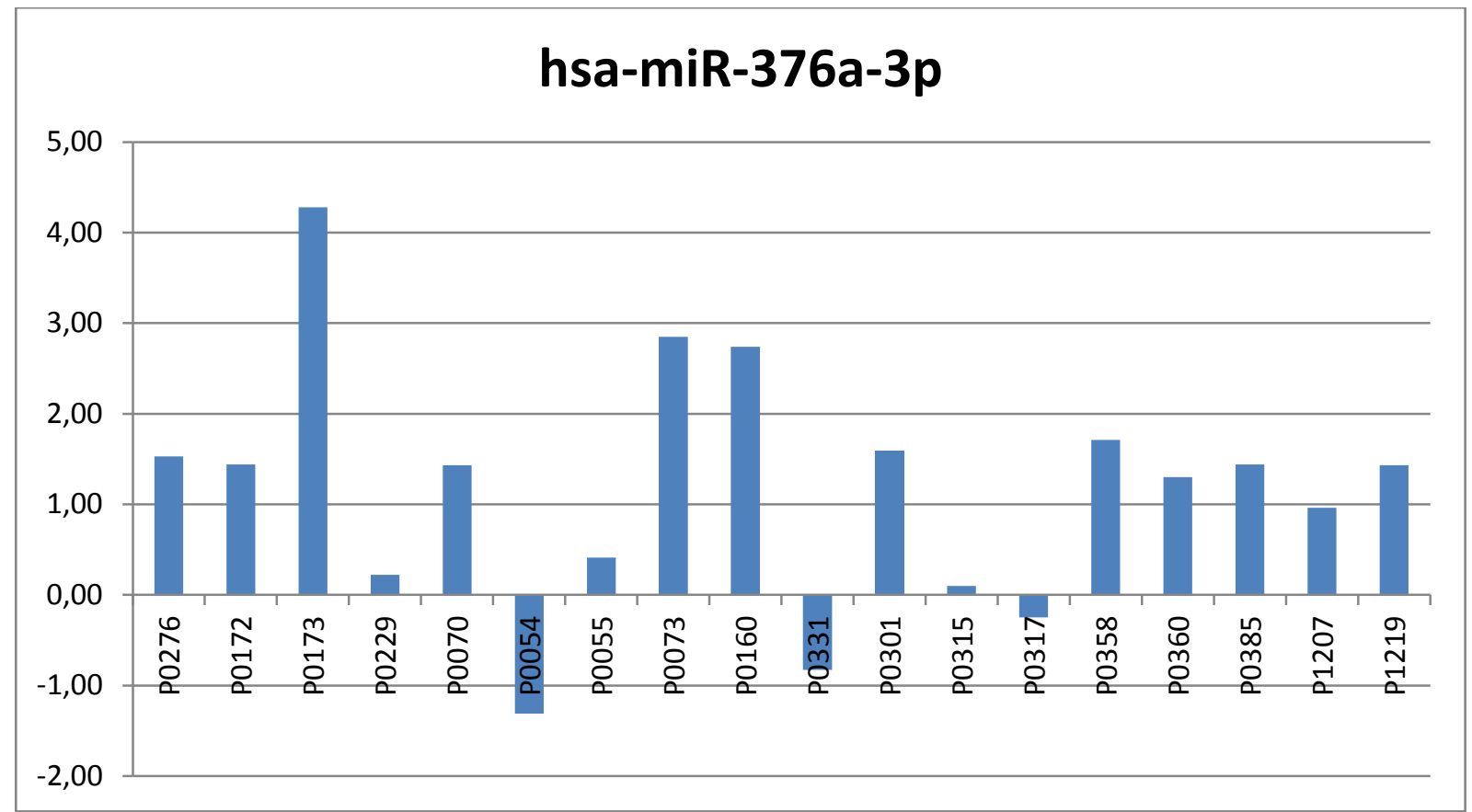

Abbildung 21: QPCR 2, Cq-Differenz (Cq-Wert[Biopsie] - Cq-Wert[Resektat]) von miR-376a-3p

Die Abbildungen 23 bis 26 fassen die Ergebnisse von QPCR 1 und QPCR 2 zusammen. Abbildung 22 erklärt die dazu gehörige farbliche Kennzeichnung.

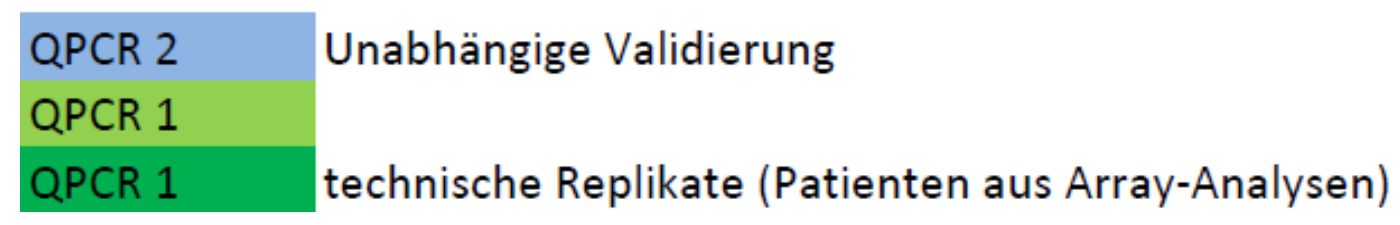

Abbildung 22: Legende für Abbildung 23 bis 26 


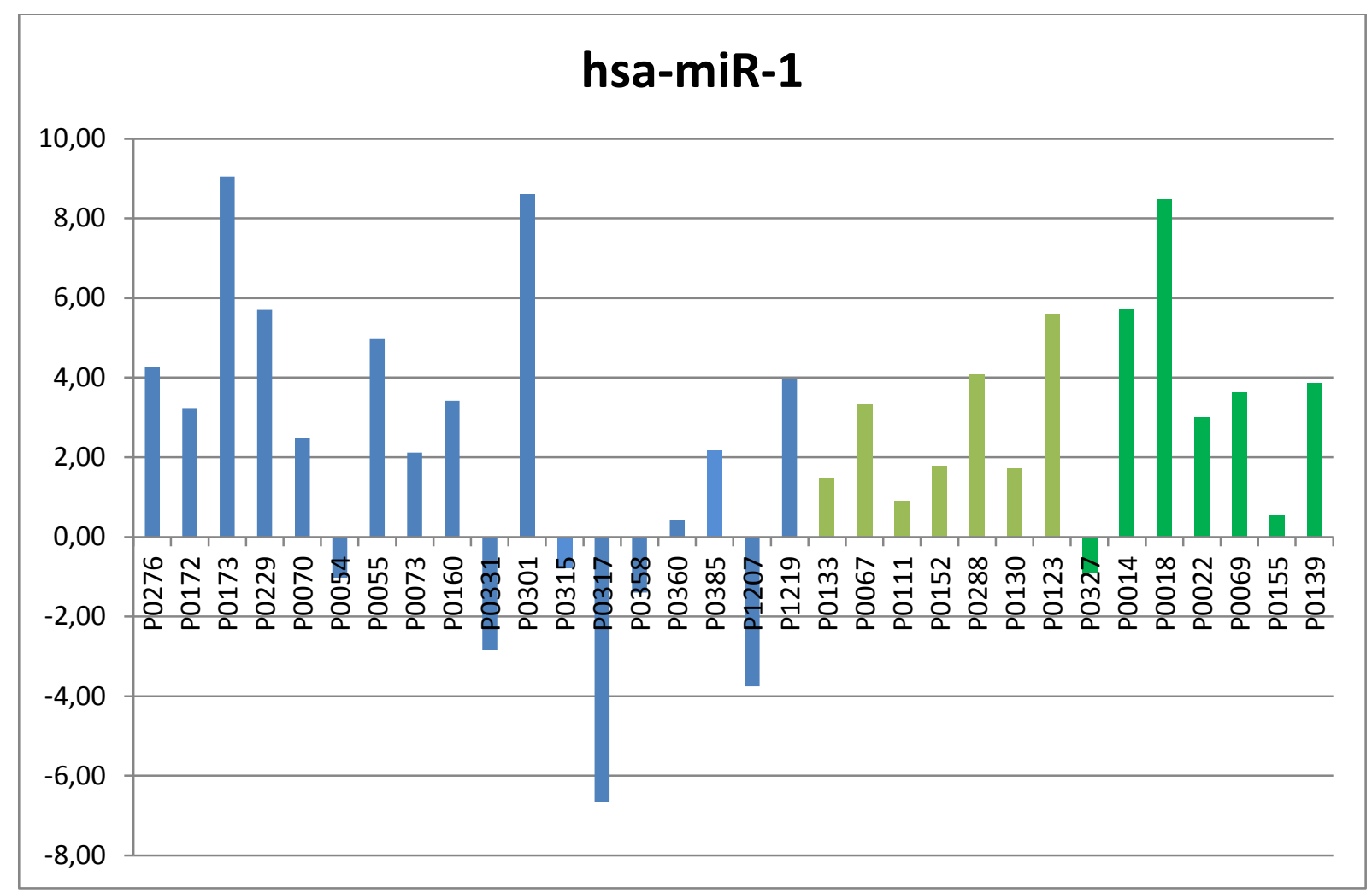

Abbildung 23: Zusammenfassung QPCR 1 und QPCR 2, Cq-Differenz (Cq-Wert[Biopsie] - CqWert[Resektat]) von miR-1

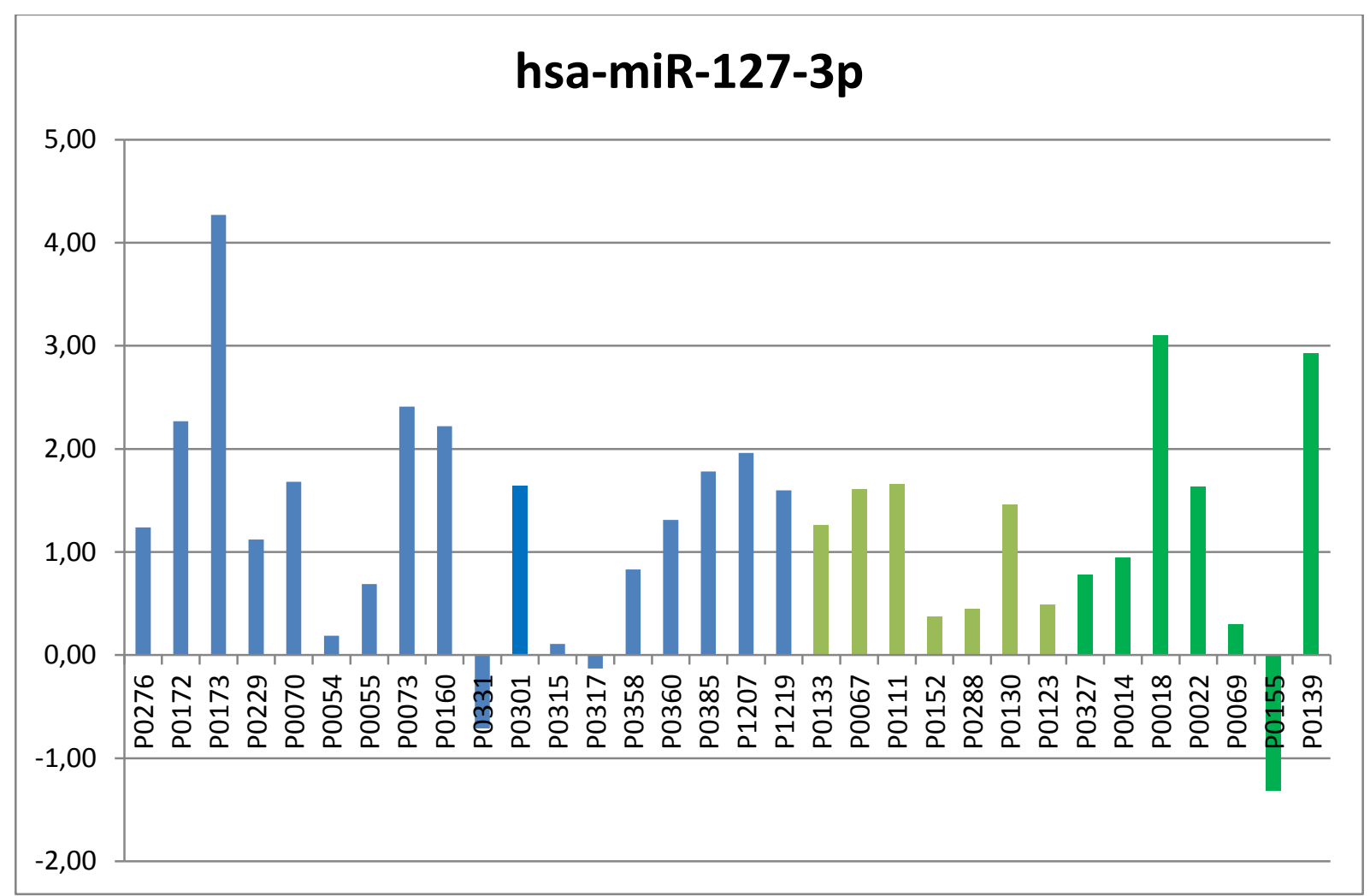

Abbildung 24: Zusammenfassung QPCR 1 und QPCR 2, Cq-Differenz (Cq-Wert[Biopsie] - CqWert[Resektat]) von miR-127-3p 


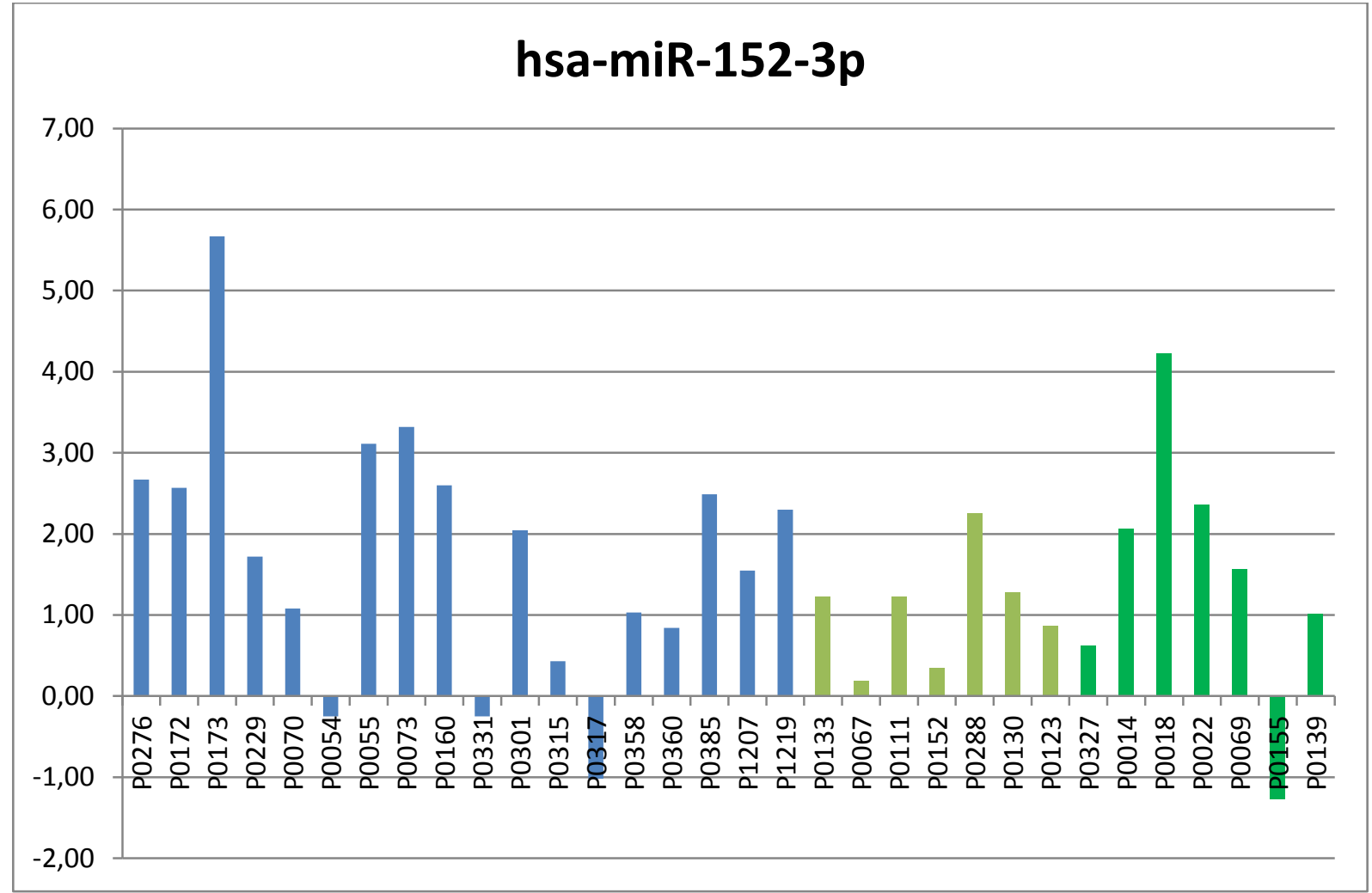

Abbildung 25: Zusammenfassung QPCR 1 und QPCR 2, Cq-Differenz (Cq-Wert[Biopsie] - CqWert[Resektat]) von miR-152-3p

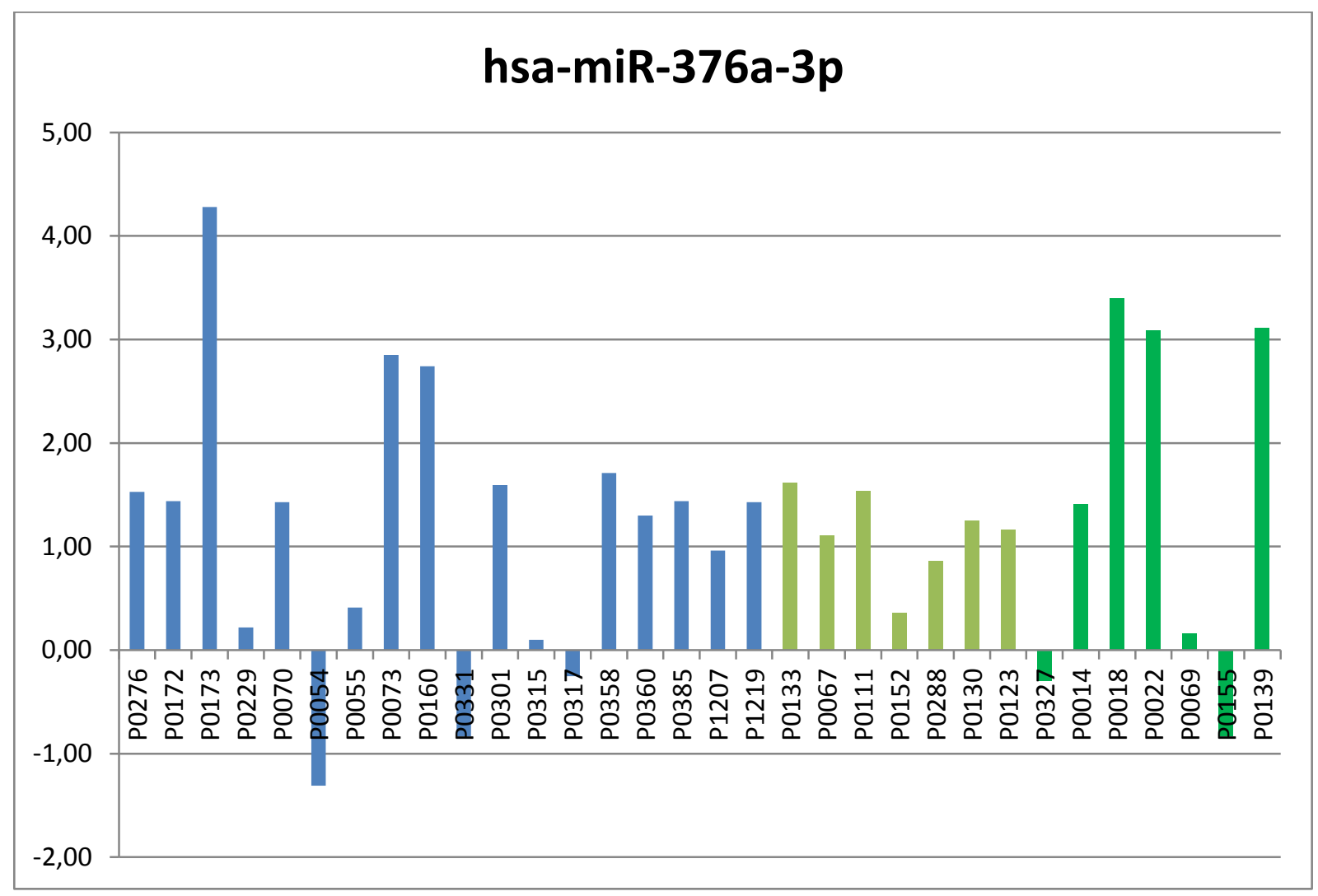

Abbildung 26: Zusammenfassung QPCR 1 und QPCR 2, Cq-Differenz (Cq-Wert[Biopsie] - CqWert[Resektat]) von miR-376a-3p 
Gemittelt auf alle 32 untersuchten Patienten ( $\Delta$ Cq-mean) ergibt sich somit jeweils mindestens eine Verdopplung $(\Delta \mathrm{C} q>1$ : mir-127-3p, mir-152-3p, mir376a-3p) bis Vervierfachung ( $\Delta \mathrm{Cq}>2$ : mir-1) der Expression.

\begin{tabular}{|c|c|c|c|}
\hline Target & $\begin{array}{c}\text { Anzahl Patienten } \\
\text { mit positivem } \\
\Delta \mathbf{C q}\end{array}$ & In Prozent & $\mathbf{\Delta C q - \text { mean }}$ \\
\hline mir-1 & $25 / 32$ & $78,1 \%$ & 2,28 \\
\hline mir-127-3p & $29 / 32$ & $90,6 \%$ & 1,26 \\
\hline mir-152-3p & $28 / 32$ & $87,5 \%$ & 1,56 \\
\hline mir-376a-3p & $27 / 32$ & $84,4 \%$ & 1,22 \\
\hline
\end{tabular}

Tabelle 10: Gesamtzusammenfassung QPCR 1 und QPCR 2 


\subsection{Auswertung Koloniebildungstest}

In Abbildung 27 und 28 ist auf der y-Achse die surviving fraction und auf der $\mathrm{x}$ Achse die Strahlendosis angegeben. Der Wert auf der der y-Achse ist praktisch als prozentualer Anteil zu verstehen ( $1=100 \%$ überlebende Zellen/Ausgangswert, 0,1=10\% überlebenden Zellen usw.). Zur besseren Veranschaulichung ist eine logarithmische Darstellung gewählt worden.

Die Koloniebildungstests wurden jeweils als Triplikate durchgeführt und hieraus der Mittelwert gebildet ( mean bei $n=3$ ). Betrachtet man nun explizit die Werte für eine Strahlendosis von 2 Gy im Vergleich zur Negativkontrolle (siNeg), so ergibt sich hieraus folgende relative Zunahme der Resistenz mit zugehörigem Standardfehler des Mittelwertes (SEM):

\begin{tabular}{|c|c|c|c|}
\hline Target/Mimic & $\begin{array}{c}\text { mean surviving } \\
\text { fraction bei } \mathbf{2} \text { Gy } \\
\mathbf{( R T )}\end{array}$ & $\begin{array}{c}\text { SEM } \\
\text { (RT) }\end{array}$ & $\begin{array}{c}\text { Relative Zunahme der } \\
\text { Resistenz zu siNeg } \\
\text { (RT) }\end{array}$ \\
\hline siNeg & 0,7402 & 0,0569 & - \\
\hline mir-1 & 0,8795 & 0,0427 & $15,84 \%$ \\
\hline mir-127-3p & 0,8519 & 0,0078 & $13,11 \%$ \\
\hline mir-376a-3p & 0,8985 & 0,0145 & $17,62 \%$ \\
\hline mir-152-3p & 0,8428 & 0,0332 & $12,17 \%$ \\
\hline
\end{tabular}

Tabelle 11: Relative Resistenzzunahme im Vergleich zur Negativkontrolle (RT)

\begin{tabular}{|c|c|c|c|}
\hline Target/Mimic & $\begin{array}{c}\text { mean surviving } \\
\text { fraction bei 2 Gy } \\
\text { (RCT) }\end{array}$ & SEM & $\begin{array}{c}\text { Relative Zunahme der } \\
\text { Resistenz zu siNeg } \\
\text { (RCT) }\end{array}$ \\
\hline siNeg & 0,6905 & 0,0577 & - \\
\hline mir-1 & 0,8132 & 0,0044 & $15,09 \%$ \\
\hline mir-127-3p & 0,7944 & 0,0163 & $13,08 \%$ \\
\hline mir-376a-3p & 0,8286 & 0,0217 & $16,67 \%$ \\
\hline mir-152-3p & 0,8099 & 0,0174 & $14,74 \%$ \\
\hline
\end{tabular}

Tabelle 12: Relative Resistenzzunahme im Vergleich zur Negativkontrolle (RCT) 


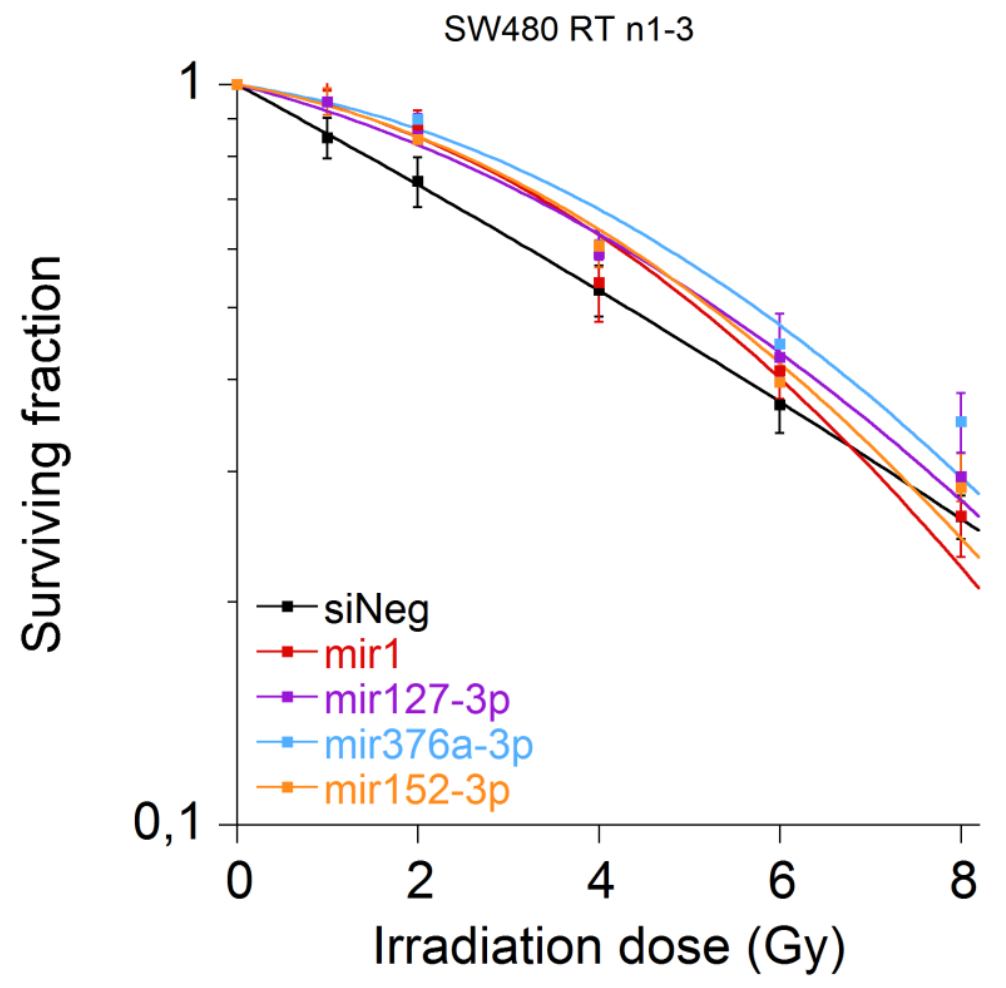

Abbildung 27: Koloniebildungstest mit Bestrahlung (0 bis 8 Gy) ohne Zusatz von 5-Fluoruracil (5-FU)

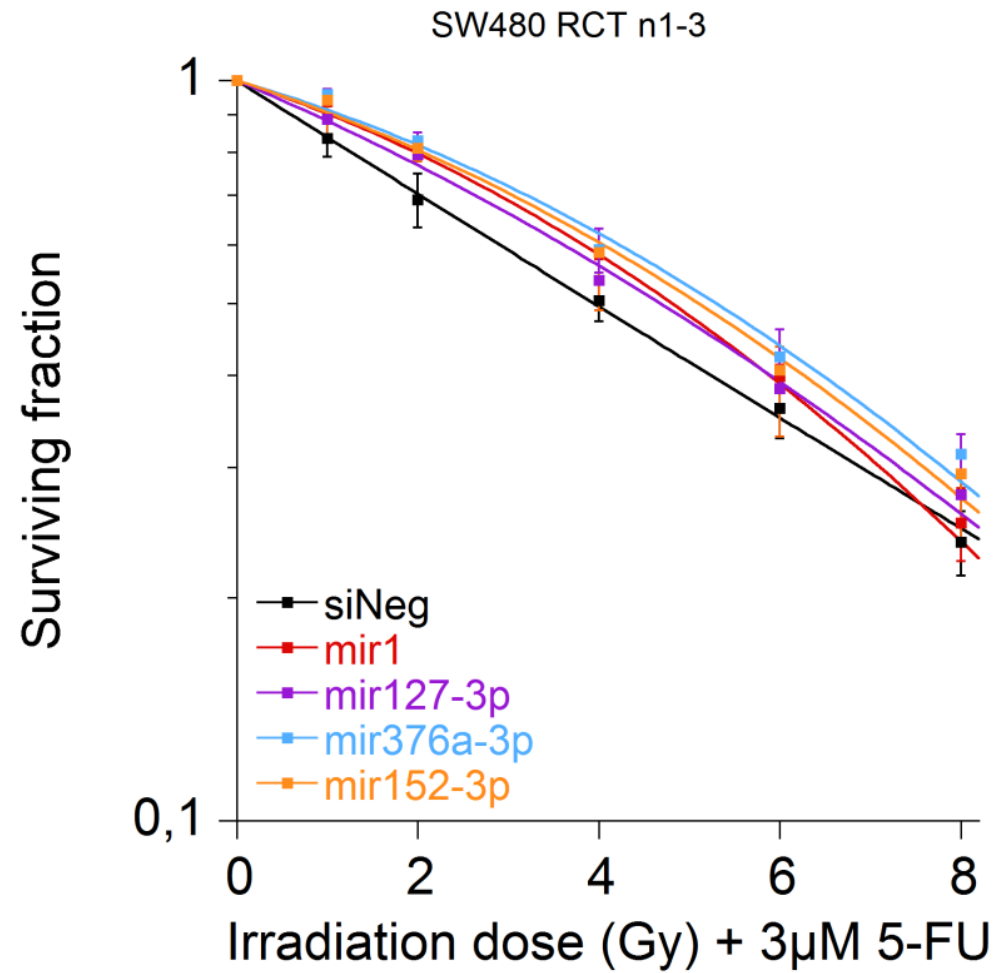

Abbildung 28: Koloniebildungstest mit Bestrahlung ( 0 bis $8 \mathrm{~Gy}$ ) und Zusatz von 5-Fluoruracil (5-FU) 
Zusammenfassend zeigt sich nach Transfektion von SW480-Zellen mit den vier microRNA-Mimics, Koloniebildungstest und Bestrahlung eine leichte Zunahme der Resistenz gegenüber einer Radiotherapie/Radiochemotherapie im Vergleich zur Negativkontrolle. Am stärksten ausgeprägt, sowohl bei alleiniger Radiotherapie als auch bei Radiochemotherapie, war dieser Effekt bei miR-376a-3p. Dies gilt insbesondere auch für den Vergleichswert bei 2 Gy. Bei miR-1, miR-127-3p und miR-152-3p und alleiniger Radiotherapie war der Effekt gleichermaßen schwächer ausgeprägt, als bei miR-376a-3p und hob sich zwischen 6 und 8 Gy wieder auf. Ein ähnliches Bild zeigen die Ergebnisse bei der Radiochemotherapie. Hier hob sich der Effekt jedoch nur bei miR-1 und 8 Gy auf.

\subsection{Vergleich der Ergebnisse mit den klinisch- pathologischen Patientendaten}

Das Biomaterial (Biopsie/Resektat) zu den Expressionsanalysen stammt von Patienten, welche in der Abteilung für Allgemein-, Viszeral- und Kinderchirurgie einem multimodalem Therapiekonzept im Rahmen der oder analog zur CAO/ARO/AIO-04-Studie zugeführt wurden. In diesem Zuge erfolgte außerdem die Erstellung einer Biodatenbank mit anonymisierter Erfassung der wesentlichen klinischen und pathologischen Parameter (z.B. cTNM-/pTNM-Stadium, TRG). Selbige wurden in einer Excel-Tabelle erfasst (siehe Tabelle 3).

Filtert man nun diese Daten nach Parametern, welche vom Prinzip einem fortgeschrittenem Tumorstadium entsprächen, so fällt beispielsweise eine relativ hohe Anzahl von Patienten mit synchron oder metachron aufgetretenen Metastasen auf (Lunge, Leber, Knochen, Nebenniere). Dies gilt für insgesamt 11 von 32 Patienten (34,4\%). Zudem fällt diesbezüglich bei genauerer Betrachtung der Cq-Differenzen auf, dass bei dem Target miR-1 ab einem $\Delta$ Cq-Wert $\geq 5,71$ alle Patienten Fernmetastasen aufweisen. 


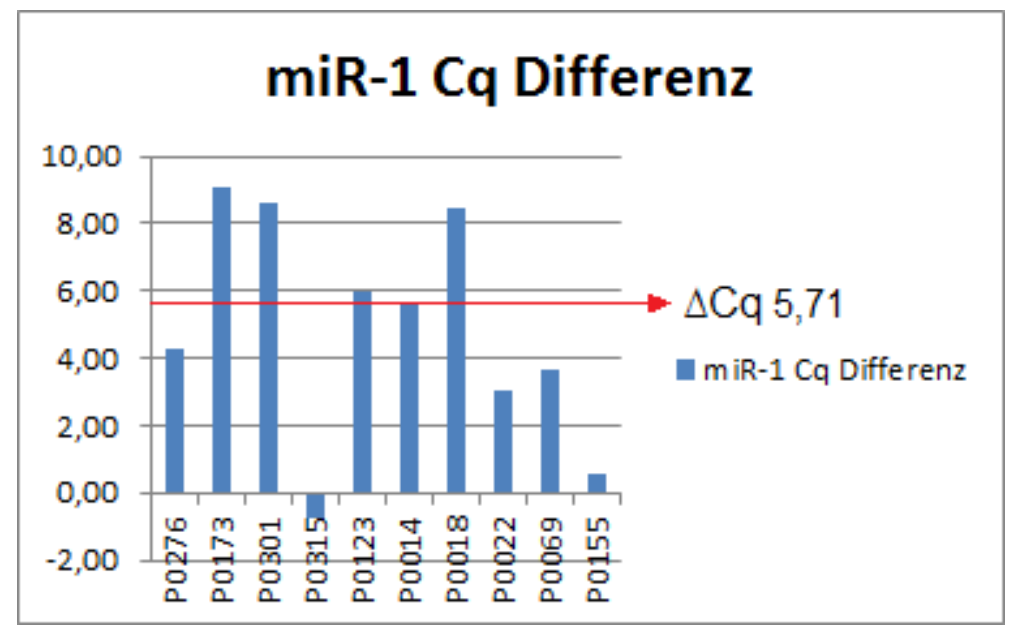

Abbildung 29: Target miR-1 nach Filter klinische Daten (aufgetretene Fernmetastasen)

Vor der neoadjuvanten Therapie wird standardmäßig ein sogenanntes cTStadium erhoben (klinisches/bildgebendes T-Stadium/auch UT-Stadium bei möglicher Endosonographie). Nach erfolgter Resektion erfolgt posttherapeutisch eine pathologische Klassifikation (pT-Stadium, siehe auch Tabelle 1). Vergleicht man nun die Tumorgröße vor und nach der Radiochemotherapie $(\Delta T$, vereinfacht als ganzer Zahlenwert/ohne Subklassifikation), so fällt auf, dass 20 von 32 (62,5\%) Patienten ein unverändertes bis erhöhtes $T$-Stadium aufweisen ( $\Delta T=0$ bzw. $\Delta T=-1)$.

Bei insgesamt 27 Patienten zeigten sich nach Resektion befallene Lymphknoten, 15 davon wiesen einen unveränderten bis verschlechterten Nodalstatus auf $(\Delta N=0$ bzw. $\Delta N=-1)$. Zudem wurde ein Patient prätherapeutisch als nodal negativ klassifiziert, im Resektat schließlich jedoch infiltrierte Lymphknoten trotz Vorbehandlung nachgewiesen. Somit ergibt sich für insgesamt 16 von 32 Patienten (50\%) eine Persistenz bzw. Progredienz des Nodalstatus. 

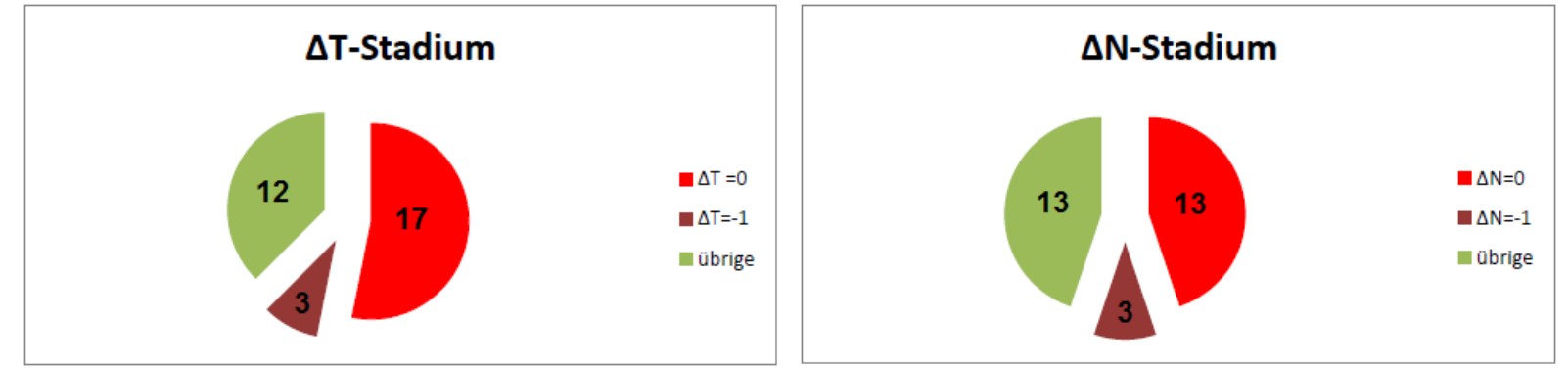

Abbildung 30: $\Delta \mathrm{T}$ - und $\Delta \mathrm{N}$-Status

Der zugehörige Tumorregressiongrad bildet dies hingegen am untersuchten Kollektiv nicht in gleicher Weise ab. Bei der Analyse des TRG in Prozent zeigt sich lediglich bei 13 von 32 Patienten (40,6\%) ein TRG $\leq 50 \%$.

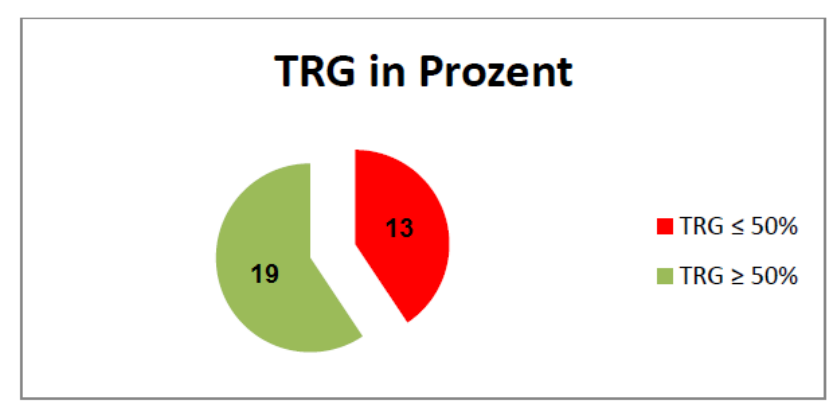

Abbildung 31: TRG in Prozent 


\section{Diskussion}

Seit ihrer Entdeckung im Jahre 1993 (Lee et al. 1993) sind microRNAs in der medizinischen Forschung ein interessanter und aussichtsreicher Ansatz im Bereich verschiedenster onkologischer und auch nicht-onkologischer Krankheitsbilder. In innen birgt sich sowohl ein diagnostisches als auch therapeutisches Potential. Binnen der relativ kurzen Zeitspanne seit ihrer Entdeckung haben einige von innen bereits den Weg in klinischtherapeutische Studien gefunden. Als prominentes Beispiel sei an dieser Stelle miR-34a genannt, welche bereits (liposomal bekapselt, als Medikament MRX34) in klinischen Phase-I-Studien getestet wird und deren Effekt bereits in vitro für epitheliale Tumoren (u. a. CRC, Pankreaskarzinom, Bronchialkarzinom) nachgewiesen wurde (Adams et al. 2015).

Im nicht-onkologischen Therapiebereich befindet sich beispielsweise das Medikament Miravirsen (Antisense-Oligonukleotid zu miR-122) sogar bereits in Phase II klinischer Studien und soll zukünftig Einzug in die Therapie der chronischen Hepatitis C erhalten (Gebert et al. 2014). Bei diesem Therapieansatz wird miR-122 gehemmt und somit die Replikation von Hepatitis-C-Viren in den Hepatozyten verhindert (Janssen et al. 2013).

Auch im diagnostischen Bereich waren insbesondere hinsichtlich des Rektumkarzinoms in den letzten Jahren erhebliche Fortschritte zu verzeichnen. So wurden beispielsweise von Yau et al. erhöhte Konzentrationen von miR-20a im Stuhl von Rektumkarzinompatienten nachgewiesen und die Ergebnisse als potentieller Biomarker hinsichtlich des Screenings der Erkrankung postuliert, wenngleich die Sensibilität mit 55\% als klare Einschränkung anzusehen ist (Yau et al. 2016).

Hinsichtlich der Umfelddiagnostik sei an dieser Stelle auch auf die Ergebnisse von Azizian et al. verwiesen. In dieser Arbeit konnte die reduzierte Serumexpression von miR-18b und miR-20a im Verlauf der multimodalen Therapie bei Rektumkarzinompatienten mit einem negativen Nodalstatus in Verbindung gebracht werden (Azizian et al. 2015). 
Die genannten Beispiele geben natürlich nur einen kleinen Ausschnitt der gesamten diagnostischen und therapeutischen Bandbreite im Bereich der microRNAs wieder, sollen aber an dieser Stelle bereits einen kleinen Ausblick zum Potential der untersuchten microRNAs im klinischen Einsatz geben. Im Folgenden werden die vier herausgearbeiteten Targets entsprechend näher beleuchtet.

\subsection{Rolle der untersuchten microRNAs beim Rektumkarzinom und anderen Tumorentitäten}

Vorab ist zusammenfassend $\mathrm{zu}$ sagen, dass $\mathrm{zu}$ den hier vorliegenden Ergebnissen nach eingehender Literaturrecherche $m$. E. bisher keine analogen Daten vorliegen. Nachfolgend wurde jedoch der Versuch unternommen, die Datenlage zu den microRNAs miR-1, miR-127-3p, miR152-3p und miR-376a-3p im Allgemeinen sowie hinsichtlich des Rektumkarzinoms und anderer Tumorentitäten zu umreißen und mit den Ergebnissen dieser Arbeit in Zusammenhang zu bringen.

\subsection{1 miR-1}

Die miR-1 zeigte in QPCR1 und QPCR2 eine deutlich erhöhte Expression im Resektat auf, verglichen mit der Expression in den zugehörigen radiochemonaiven Biopsien. Daher liegt es nahe zu vermuten, dass die miR-1 eine Rolle in der Resistenzentwicklung gegenüber der Radiochemotherapie spielt. In den QPCR-Analysen dieser Arbeit zeigte sich bei diesem Target zwar die geringste Anzahl an Patienten mit insgesamt positiven $\Delta$ Cq-Werten $(78,1 \%)$, jedoch fand sich hier auch gemittelt auf das gesamte Kollektiv die höchste gemittelte Differenz ( $\Delta$ Cq-mean: 2,28). Bei den CFU-Assays hingegen fiel der Effekt der Resistenzzunahme im Vergleich zu den übrigen Targets eher mäßig ausgeprägt aus.

MiR-1 und seine strukturell verwandten Formen (miR-1b, -1-1 und 1-2) bilden ein eigenständiges Cluster der Gens MIPF0000038. Die Informationen hierzu 
liegen auf Chromosom $20 \quad$ (http://www.mirbase.org/cgi-

bin/mirna_entry.pl?acc=MI0000651).

Die überwiegende Anzahl an Daten zu diesem Target finden sich im Übrigen eher in Zusammenhang mit kardialen Erkrankungsbildern wie Arrhythmien, Hypertrophie und Herzinfarkten bzw. generell im Kontext zur Muskelphysiologie allgemein. Su et al. konnten beispielsweise nachweisen, dass eine Überexpression von miR-1 in Herzmuskelzellen eine Störung der intrazellulären Signalkaskade bewirken (Su et al. 2017). Zudem ist dieses Target scheinbar entscheidend bei der Rekonvaleszenz nach akutem Myokardinfarkt beteiligt (Grabmeier et al. 2017).

Es finden sich jedoch auch vereinzelt Daten zum CRC oder in Zusammenhang mit Bestrahlungstherapien bei anderen Tumorentitäten.

Eine Forschungsgruppe der Universität Utah unternahm eine matched-pairsAnalyse von gesundem Mukosagewebe im Vergleich zum kolorektalen Karzinomgewebe. Bei Patienten im Stadium I und II konnte die Anwesenheit von miR-1 im Tumorgewebe mit einem schlechteren Überleben assoziiert werden (Slattery et al. 2016). Oberg et al. konnten zudem einen zumindest statistischen Zusammenhang zu der Expression von miR-1 in der Karzinogenese (Adenom-Dysplasie-Karzinom-Sequenz) abbilden (Oberg et al. 2011).

In einer In-vitro-Analyse konnten Pathak et al. zeigen, dass miR-1 ein aussichtsreiches Target bei der Behandlung kolorektaler Karzinome darstellen könnte. Die Arbeitsgruppe untersuchte die Expression verschiedener microRNAs nach Behandlung mit SN38 (ein aktiver Metabolit von Irinotecan) und nachfolgender Bestrahlung. In der Auswertung fand sich miR-1 herunterreguliert (Pathak et al. 2015). Interessant sind in dieser Arbeit außerdem ähnliche Ergebnisse zu miR-127, allerdings in der ,5p'- und nicht wie hier in der ,3p'-Form.

Mit HCT116-Zellen wurde eine zu den Ergebnissen dieser Arbeit (SW480) abweichende Zelllinie verwendet, welche an sich ein sensibleres Grundmuster 
gegenüber einer RCT aufweist (Spitzner et al. 2010). Zudem lag der Auswertungsschwerpunkt bei Pathak et al. nicht bei der Durchführung von Koloniebildungstest, sodass auch aus diesem Grund ein direkter Vergleich der Ergebnisse erschwert ist. Zusätzlich wurde mit dem Topoisomerase-I-Inhibitor SN38 ein anderes Chemotherapeutikum zur Vorbehandlung verwandt. Postuliert man jedoch den nachgewiesenen Effekt der miR-1Herunterregulierung bei Pathak et al. als Auswirkung der Vorbehandlung, so unterstreicht dies ebenso das therapeutische Potential.

Unsere initiale Hypothese war, dass es eine kleine Population maligner Zellklone gibt, welche durch die höhere Expression bestimmter microRNAs eine Radiochemotherapie besser überleben, oder, dass solche resistenteren Zellklone unter der Therapie entstehen können. Am oben genannten Beispiel von Miravirsen konnte bereits gezeigt werden, dass der Einsatz solcher Antisense-Oligonukleotide prinzipiell möglich scheint und somit auch hier einen potentiellen Therapieansatz darstellt. Grundlegend wären hierfür natürlich zunächst weiterführende Untersuchungen sinnvoll, welche weiter unten im Text noch Erwähnung finden.

Im Zusammenhang mit epithelialen Tumoren und Strahlentherapie sind am Beispiel des Nasopharynxkarzinoms jedoch auch entgegengesetzte Ergebnisse in der Literatur zu finden. So wurde durch Jin et al. die Vermutung aufgestellt, dass miR-1 indirekt (über mögliche Herunterregulierung von MALAT1/slug) einen günstigen Effekt auf das Therapieansprechen haben könnte (Jin et al. 2015). Der divergente Untersuchungsfokus (z.B. Radio- vs. Radiochemotherapie) ist ein möglicher Grund für diesen scheinbaren Widerspruch. Zudem sind microRNAs in ihrer Expression und Funktion zellund gewebespezifisch (Ribeiro et al. 2014). Das heißt, in unterschiedlichen Gewebearten (gesundes und Tumorgewebe gleichermaßen) können microRNAs durchaus unterschiedliche Targets haben und zu verschiedensten Effekten führen. 


\subsection{2 miR-127-3p}

In Hinblick auf die Expressionanalysen fand sich bei diesem Target die höchste Anzahl an Patienten mit positivem $\Delta$ Cq-Wert (29 von 32 Patienten) und die zweithöchste gemittelte Gesamtdifferenz ( $\Delta$ Cq-mean 1,26). Auf der anderen Seite zeigten sich bei den Koloniebildungstests hier die geringste relative Zunahme der Resistenz im Vergleich zu siNeg bei der Radiochemotherapie und der zweitgeringste Effekt bei alleiniger Bestrahlung.

MiR-127-3p gehört gemeinsam mit miR-433 zur Gen-Familie MIPF0000080. Die genetischen Informationen hierzu liegen auf Chromosom 14. Zum gemeinsamen Cluster gehören insgesamt noch sechs weitere microRNAs. Bisher wurden diesem Target überwiegend regulatorische Fähigkeiten hinsichtlich Lungenentwicklung und Apoptose zugeschrieben (http://www.mirbase.org/cgi-bin/mirna_entry.pl?acc=MI0000472).

In der Literatur finden sich jedoch zudem einige Assoziationen mit soliden Tumoren.

Mosakhani et al. untersuchten Primärtumore von 60 Patienten mit unbehandeltem metastasierten $\mathrm{CRC}$ hinsichtlich ihrer microRNA-Signaturen und stellten einen Bezug zum KRAS-Status her. Bei 15 der untersuchten Tumoren lag eine KRAS-Mutation vor und selbige konnte mit der Hochregulation von miR-127-3p, im Vergleich zu gesundem Kolongewebe, assoziiert werden (Mosakhani et al. 2012). Eine weiterführende Signalweganalyse dieser und weiterer untersuchter microRNAs ließ einen zusätzlichen Zusammenhang zur EGFR/KRAS-Signalkaskade vermuten. In Zusammenschau dieser Ergebnisse ist dies insofern interessant, da bekanntermaßen der KRAS-Status in der Auswahl des Chemotherapieregimes eine zentrale Bedeutung einnimmt. Tumoren, welche eine KRAS-Mutation ausweisen, sprechen schlechter auf eine Therapie mit Anti-EGFR-gerichteten monokonalen Antikörpern (z.B. Cetuximab) an oder können gar gegenteilige Effekte mit Reduktion des Gesamtüberlebens nach sich ziehen (Douillard et al. 2010). Sollte es möglich sein, die Mitbeteiligung zwischen einer miR-127-3p- 
Deregulierung und dieser Tatsache weiter zu erhärten, so böte sich auch hier möglicherweise ein interessanter Therapieansatz.

Hinsichtlich des diagnostischen Potentials von miR-127-3p konnte eine Forschungsgruppe der Universitätsklinik Heidelberg erhöhte Plasmaspiegel bei Mammakarzinompatientinnen nachweisen. You et al. kamen zu vergleichbaren Ergebnissen hinsichtlich des Cervixkarzinoms, ebenso Zhang et al. bei Patienten mit Ösophaguskarzinom (Cuk et al. 2013; You et al. 2015; Zhang et al. 2010). Interessanterweise zeigten sich bei Cuk et al. des Weiteren erhöhte Werte für Vertreter der miR-376-Gruppe (miR-376a und 376c), wenngleich sich die untersuchten microRNAs bei der Untersuchung des primären Tumorgewebes in benignen Befunden höher als in malignen darstellten. Für das kolorektale Karzinom bestehen derzeit noch keine derart vergleichbaren Plasmadaten. Eine entsprechende Analyse könnte möglicherweise wichtige Erkenntnisse liefern.

Weiteres onkogenes Potential fand sich für miR-127-3p im Bereich von NonHodgkin-Lymphomen (assoziiert mit aggressiverer Verlaufsform) und in invitro-Analysen von Glioblastomzellen, wo eine erhöhte Zellmigration durch Inhibierung des Tumorsuppressorgens SEPT7 nachgewiesen werden konnte (Goswami et al. 2013; Jiang et al. 2014).

Dass sich auch Arbeiten $\mathrm{zu}$ miR-127-3p in Zusammenhang mit tumorsupprimierendem Effekt finden lassen, unterstreicht erneut die intertumorale Heterogenität und die bereits erwähnte Gewebespezifität der microRNAs. So postulieren Zhou et al. einen wachstumshemmenden Effekt beim hepatozellulären Karzinom (Zhou et al. 2014).

\subsection{3 miR-376a-3p}

MiR-376a-3p gehört gemeinsam mit miR-368 zur Gen-Familie MIPF0000091. Die genetischen Informationen hierzu liegen ebenfalls auf Chromosom 14 (http://www.mirbase.org/cgi-bin/mirna entry.pl?acc=Ml0000784). Zum gemeinsamen Cluster gehören insgesamt noch 15 weitere microRNAs. 
In Hinblick auf die Ergebnisse des Koloniebildungstests (siehe 3.3) zeigte sich bei diesem Target die größte Resistenzzunahme. Auch in der Literatur finden sich viele Zusammenhänge zur Begünstigung von Tumorwachstum.

Mo et al. verglichen die Expression von miR-376a bei Patienten mit kolorektalem Karzinom im Vergleich zu benachbartem Mukosagewebe. Bei Tumoren mit einer erhöhten Expression zeigte sich eine Korrelation i.S. einer tendenziell fortgeschrittenen Lymphknotenmetastasierung, sowie eines kürzeren Langzeitüberlebens (Mo et al. 2014). Des Weiteren wurden immunhistochemische Analysen hinsichtlich der Expression von VEGF (vascular endothelial growth factor) durchgeführt. Hier konnte ebenfalls eine positive Korrelation mit hoher Expression von miR-376a nachgewiesen werden. Wenngleich diese Untersuchungen nicht das Ziel hatten, Zusammenhänge zur Durchführung und Problematik einer Radiochemotherapie abzubilden, so unterstützen sie das onkogene Potential von miR-376a.

Ähnliche Daten finden sich auch im Zusammenhang mit anderen Tumoren. Eine Arbeitsgruppe der Universität in Ohio konnte anhand der erhöhten miR376a-Expression Pankreastumoren von umliegendem, gesundem Stroma- und Drüsengewebe unterscheiden (Lee et al. 2007). Zudem konnten Yabushita et al. erhöhte miR-376a-Spiegel in Rattenserum bei vorliegendem Pankreaskarziom nachweisen (Yabushita et al. 2012). In einem ebenfalls 32 Patienten umfassenden Kollektiv konnte eine Forschungsgruppe um Yang et al. aufzeigen, dass die Überexpression von miR-376a eine Steigerung der Proliferation, Migration und Invasivität beim Ovarilakarzinom nach sich zieht (Yang et al. 2017). Außerdem steht dieses Target, ebenso wie bereits oben erwähnte miR-127-3p, möglicherweise in Zusammenhang mit der Zellinvasion und -migration von Glioblastomzellen (Choudhury et al. 2012).

Die funktionell wohl relevantesten Parallelen zu diesem Target finden sich im Kontext mit einer Platin-basierten, neoadjuvanten Radiochemotherapie beim Ösophaguskarzinom. Eine Arbeitsgruppe des Sun Yat-sen University Cancer Centers konnte ein multivariates Vorhersagetool aufzeigen, bei welchem die 
Hochregulation von miR-376a-3p zu einem schlechteren Ansprechen auf eine Vortherapie führt (Wen et al. 2016).

In Zusammenschau der Literaturdaten und den Ergebnissen dieser Arbeit ist somit diesem Target das wohl stärkste onkogene Potential zu unterstellen.

\subsection{4 miR-152-3p}

MiR-152-3p gehört gemeinsam mit miR-148 zur Gen-Familie MIPF0000056. Diese beiden microRNAs bilden zudem ein eigenständiges Cluster. Die genetischen Informationen hierzu liegen auf Chromosom 17 (http://www.mirbase.org/cgi-bin/mirna entry.pl?acc=Ml0000462).

Hier fand sich bei der Auswertung der CFU-Assays (hinsichtlich der relativen Resistenzzunahme bei 2 Gy) bei der RT der geringste (12,17\%) und bei der RCT (14,74\%) der zweitgeringste Effekt.

$\mathrm{Zu}$ diesem Target sind die Literaturdaten, insbesondere hinsichtlich solider Tumoren und Daten zum CRC, eher spärlich und zudem scheinbar widersprüchlich. So finden sich bei beiden Vertretern dieser Gen-Familie sowohl onkogene, als auch Tumorsuppressor-Eigenschaften (Friedrich et al. 2017). Miao et al. fanden beispielsweise heraus, dass eine erhöhte Plasmaexpression des gesamten Clusters (miR-152 und -148) mit einem längeren disease-free- und progression-free-survival bei Patienten mit hepatozellulärem Karzinom sowie nicht-kleinzelligem Lungenkarzinom korrelieren (Miao et al. 2017). Dies gilt den Daten zufolge jedoch nur für die asiatische Bevölkerung. Für kaukasische Patienten ließ sich kein signifikanter Zusammenhang abbilden. Insbesondere ergab die Metaanalyse auch, dass hinsichtlich des CRC (und zudem beim Magenkarzinom) über alle Bevölkerungsgruppen jeglicher signifikanter Zusammenhang fehlt.

Eine Forschungsgruppe der Universität Chicago erbrachte hingegen kürzlich den Zusammenhang zwischen einer erhöhten Plasmaexpression von miR-152 und der frühen Detektion verschiedener solider Tumoren (Kolorektales Karzinom, Prostatakarzinom, Lungekarzinom und Mammakarzinom). 
Hinsichtlich des kolorektalen Karzinoms konnte gar zwischen benignen und malignen Befunden unterschieden werden. Bei letzteren zeigte sich die Expression noch stärker erhöht (Chen et al. 2016). Ein direkter Zusammenhang zwischen der Expression von microRNAs im Plasma und den zugehörigen Primärtumoren ist nicht immer zwingend vorhanden. Ebenso wenig wurde durch Chen et al. eine Wertung vorgenommen, ob die Hochregulation Ausdruck des frühen Tumorwachstums ist oder der Organismus hierüber versucht tumorsupprimierenden Einfluss zu nehmen. Da sich jedoch nahezu kongruente Daten für gleich vier solide Tumoren darstellen, ist $\mathrm{m}$. E. eher von ersterem auszugehen und unterstützt prinzipiell die Ergebnisse dieser Arbeit.

\subsection{Vergleich der Ergebnisse mit klinisch-pathologischen Patientendaten und Ausblick}

Einschränkend ist sicherlich anzumerken, dass für statistisch fundierte Aussagen das 32 Patienten umfassende Kollektiv hierfür insgesamt zu klein ist. Betrachtet man jedoch im Einzelnen näher die klinischen und pathologischen Parameter des Kollektivs, zeichnet sich insgesamt ein tendenziell eher mäßig bis schlechtes Therapieansprechen ab (siehe Abb. 30), was insgesamt die Ergebnisse dieser Arbeit und die funktionelle Relevanz der untersuchten Targets weiter unterstützt. Passend hierzu finden sich Parallelen in den Literaturdaten, beispielsweise hinsichtlich der o.g. fortgeschrittenen Lymphknotenmetastasierung (Mo et al. 2014).

Die diagnostischen und therapeutischen Möglichkeiten, welche sich durch microRNAs bieten, wurden unter 4.1 bereits angeschnitten. Bekanntermaßen ist der Prozess, den neue Therapiestrategien in klinischen Studien vor ihrer 
Anwendung durchlaufen, oft sehr langwierig und setzt weiterführende Untersuchungen voraus. Anhand der vier untersuchten microRNAs konnte eine differente Expression nach Radiochemotherapie und schließlich ein zumindest in vitro resistenzvermitteltender Effekt nachgewiesen werden. Den verantwortlichen Mechanismus auf molekularer Ebene bleibt diese Arbeit jedoch schuldig und wird Gegenstand weiterführender Untersuchungen bleiben müssen.

Denkbar wären diesbezüglich beispielsweise In-situ-Hybridisierungen. In Zusammenhang mit genetischen Untersuchungen an Tumoren wird vielfach der Begriff der Tumorheterogenität bemüht. Auch in Zusammenhang mit der vorliegenden Arbeit wird dieser als eine Möglichkeit der differenten Expression unter Abbildung 5 postuliert. Eriksen et al. konnten diese Gegebenheit bereits kürzlich für fünf microRNAs nachweisen (miR-21, miR-31, miR-125b, miR-145 und miR-630). Die Forschungsgruppe aus Dänemark konnte Anhand von Insitu-Hybridisierungen eine Verteilung analog des zweiten Schaubildes aus Abbildung 5 aufzeigen (Eriksen et al. 2016). Würde sich dies auch für die in dieser Arbeit untersuchten Targets reproduzieren lassen, böten sich weitere interessante Ansätze hinsichtlich des klinischen Einsatzes. So könnten beispielsweise prätherapeutische Biopsien via In-situ-Hybridisierung untersucht werden und ein erhöhtes Aufkommen einer oder mehrerer der vier Targets mit Parametern für das Ansprechen auf die neoadjuvante Radiochemotherapie verglichen werden (Tumorregressionsgrad, yTNMStatus). Gegebenenfalls ergäbe sich hieraus eine gewisse Vorhersagekraft. Auch ein direkter Vergleich mit dem histologischen Präparat nach erfolgter Resektion könnte sehr aufschlussreich sein. Angenommen hier zeigte sich bei der überwiegenden Anzahl der Zellen, welche die Vortherapie ,überlebt' haben, ein erhöhter Anteil mit Expression einer oder mehrerer dieser Targets, so würde dies die Theorie der bereits angesprochenen intrinsischen Strahlensensibilität weiter unterstützen. 


\section{Zusammenfassung}

Die klinischen Verläufe von vergleichbaren Patienten (gleiches Tumorstadium, Alter, Geschlecht und vergleichbare histopathologische Parameter), welche an einem Rektumkarzinom leiden, können sehr variieren. Die Spannweite der Ansprechraten auf die neoadjuvante Radiochemotherapie ist sehr groß und reicht von Komplettremission bis zu weitgehender Strahlenresistenz bzw. Progress der Erkrankung unter der Vortherapie.

In der vorliegenden Arbeit konnte gezeigt werden, dass microRNAs in diesem Zusammenhang eine Rolle spielen könnten. In einer genomweiten ArrayAnalyse wurden zunächst aussichtsreiche Targets identifiziert, welche in der prätherapeutischen Biopsie wesentlich geringer als im residuellen Tumor exprimiert sind. Von insgesamt zehn ausgewählten Targets konnten schließlich vier mittels PCR unabhängig validiert werden. Die funktionelle Relevanz dieser Ergebnisse ließen schließlich die angeschlossenen Koloniebildungstests vermuten. Hier zeigte sich, dass eine Überexpression der microRNAs miR-1, miR-127-3p, miR-152-3p und miR-376a-3p mit einer etwas erhöhten, wenngleich unterschiedlich ausgeprägten Resistenz gegen eine Radiochemotherapie einherging. Der stärkste Unterschied fand sich hier bei miR-376a-3p. Auch in Anbetracht der Literaturdaten ist diesem Target das wohl stärkste onkogene Potential der hier untersuchten Targets zuzuschreiben. Zudem zeichnete sich nach der Analyse der zugehörigen klinisch-pathologischen Patientendaten ein insgesamt eher mäßig bis schlechtes Therapieansprechen ab.

In Hinblick auf den klinischen Nutzen dieser Ergebnisse kämen verschiedene Ansätze in Betracht. Sowohl diagnostische als auch therapeutische Anwendungen wären denkbar. Hierfür bedarf es jedoch zwingend noch weiterer Untersuchungen. Interessant wäre beispielsweise, ob sich mit Antisense-Oligonukleotiden zu den untersuchten Targets in vitro tatsächlich gegenteilige Effekte erreichen ließen. Ebenfalls vielversprechend hinsichtlich der weiteren Suche nach einem adäquatem „Vorhersage-Tool“, wären m. E. 
In-situ-Hybridisierungen vor und nach einer neoadjuvanten Radiochemotherapie. 


\section{Literaturverzeichnis}

Adams BD, Parsons C, Slack FJ (2015): The tumor-suppressive and potential therapeutic functions of miR-34a in epithelial carcinomas. Expert Opin Ther Targ 20, 737-753

Azizian A, Kramer F, Jo P, Wolff HA, Beissbarth T, Skarupke R, Bernhardt M, Grade M, Ghadimi BM, Gaedcke J (2015): Preoperative Prediction of Lymph Node Status by Circulating Mir-18b and Mir-20a During Chemoradiotherapy in Patients with Rectal Cancer. World J Surg 39, 2329-2335

Bader AG, Brown D, Stoudemire J, Lammers P (2011): Developing therapeutic microRNAs for cancer. Gene Ther 18, 1121-1126

Chen H, Liu H, Zou H, Chen R, Dou Y, Sheng S, Dai S, Ai J, Melson J, Kittles RA (2016): Evaluation of Plasma miR-21 and miR-152 as Diagnostic Biomarkers for Common Types of Human Cancers. J Cancer $\underline{7}$, 490-499

Choudhury Y, Tay FC, Lam DH, Sandanaraj E, Tang C, Ang BT, Wang S (2012): Attenuated adenosine-to-inosine editing of microRNA-376a promotes invasiveness of glioblastoma cells. J Clin Invest 122, 4059-4076

Cuk K, Zucknick M, Madhavan D, Schott S, Golatta M, Heil J, Marme F, Turchinovich A, Sinn P, Sohn C (2013): Plasma microRNA panel for minimally invasive detection of breast cancer. PLoS One $\underline{8}$, e76729

Donadeu FX, Schauer SN, Sontakke SD (2012): Involvement of miRNAs in ovarian follicular and luteal development. J Endocrinol 215, 323-334 
Douillard JY, Siena S, Cassidy J, Tabernero J, Burkes R, Barugel M, Humblet Y, Bodoky G, Cunningham D, Jassem J (2010): Randomized, phase III trial of panitumumab with infusional fluorouracil, leucovorin, and oxaliplatin (FOLFOX4) versus FOLFOX4 alone as first-line treatment in patients with previously untreated metastatic colorectal cancer: the PRIME study. J Clin Oncol 28, 4697-4705

Eriksen AH, Andersen RF, Nielsen BS, Sorensen FB, Appelt AL, Jakobsen A, Hansen TF (2016): Intratumoral heterogeneity of microRNA Expression in rectal cancer. PLoS One 11, e0156919

Fearon ER, Vogelstein B (1990): A genetic model for colorectal tumorigenesis. Cell $\underline{61}, 759-767$

Fire A, Xu S, Montgomery MK, Kostas SA, Driver SE, Mello CC (1998): Potent and specific genetic interference by double-stranded RNA in Caenorhabditis elegans. Nature $\underline{391}, 806-811$

Friedrich M, Pracht K, Mashreghi MF, Jack HM, Radbruch A, Seliger B (2017): The role of the miR-148/-152 family in physiology and disease. Eur J Immunol $\underline{47}, 1-13$

Fuchs R GD, Neumann U, Trautwein C: Diagnostik und Therapie gastrointestinaler Tumore 2014. 13. Auflage; Nora-Verlag, Stolberg 2014

Gaedcke J, Liersch T, Hess C, Becker H, Rodel C, Ghadimi BM (2011): Rectal cancer: current status of multimodal therapy--when and how. Zentralbl Chir $\underline{136}, 334-342$ 
Gebert LF, Rebhan MA, Crivelli SE, Denzler R, Stoffel M, Hall J (2014): Miravirsen (SPC3649) can inhibit the biogenesis of miR-122. Nucleic Acids Res $\underline{42}, 609-621$

Goswami RS, Atenafu EG, Xuan Y, Waldron L, Reis PP, Sun T, Datti A, Xu W, Kuruvilla J, Good DJ (2013): MicroRNA signature obtained from the comparison of aggressive with indolent non-Hodgkin lymphomas: potential prognostic value in mantle-cell lymphoma. J Clin Oncol 31, 2903-2911

Grabmaier U, Clauss S, Gross L, Klier I, Franz WM, Steinbeck G, Wakili R, Theiss HD, Brenner C (2017): Diagnostic and prognostic value of miR-1 and miR-29b on adverse ventricular remodeling after acute myocardial infarction The SITAGRAMI-miR analysis. Int J Cardiol 244, 30-36

Hotchi M, Shimada M, Kurita N, Iwata T, Sato H, Morimoto S, Yoshikawa K, Higashijima J, Miyatani T (2013): microRNA expression is able to predict response to chemoradiotherapy in rectal cancer. Mol Clin Oncol 1, 137-142

Janssen HL, Reesink HW, Lawitz EJ, Zeuzem S, Rodriguez-Torres M, Patel K, van der Meer AJ, Patick AK, Chen A, Zhou Y (2013): Treatment of HCV infection by targeting microRNA. N Engl J Med $\underline{368}, 1685-1694$

Jiang H, Hua D, Zhang J, Lan Q, Huang Q, Yoon JG, Han X, Li L, Foltz G, Zheng S (2014): MicroRNA-127-3p promotes glioblastoma cell migration and invasion by targeting the tumor-suppressor gene SEPT7. Oncol Rep 31, 22612269

Jin C, Yan B, Lu Q, Lin Y, Ma L (2015): The role of MALAT1/miR-1/slug axis on radioresistance in nasopharyngeal carcinoma. Tumor Biol $\underline{37}, 4025-4033$

Karstens JH, Janssen S, Werner M, Meyer A, Bruns F,Meier K, Bremer M: 
Strahlentherapie und Radioonkologie aus interdisziplinärer Sicht, 5. Auflage. Lehmanns Media, Berlin 2010

Kim VN, Nam JW (2006): Genomics of microRNA. Trends Genet 22, 165-173

Ladanyi M, Chan WC, Triche TJ, Gerald WL (2001): Expression profiling of human tumors: the end of surgical pathology? J Mol Diagn $\underline{3}$, 92-97

Lee EJ, Gusev Y, Jiang J, Nuovo GJ, Lerner MR, Frankel WL, Morgan DL, Postier RG, Brackett DJ, Schmittgen TD (2007): Expression profiling identifies microRNA signature in pancreatic cancer. Int J Cancer 120, 1046-1054

Lee RC, Feinbaum RL, Ambros V (1993): The C. elegans heterochronic gene lin-4 encodes small RNAs with antisense complementarity to lin-14. Cell $\underline{75}$, 843-854

Lindl G: Zell- und Gewebekultur. 5. Auflage; Spektrum, Heidelberg 2002

Metheetrairut C, Slack FJ (2013): MicroRNAs in the ionizing radiation response and in radiotherapy. Curr Opin Genet Dev $\underline{23}, 12-19$

Miao C, Zhang J, Zhao K, Liang C, Xu A, Zhu J, Wang Y, Hua Y, Tian Y, Liu S (2017): The significance of microRNA-148/152 family as a prognostic factor in multiple human malignancies: a meta-analysis. Oncotarget $\underline{8}, 43344-43355$

Mo ZH, Wu XD, Li S, Fei BY, Zhang B (2014): Expression and clinical significance of microRNA-376a in colorectal cancer. Asian Pac J Cancer Prev $\underline{15}, 9523-9527$

Mosakhani N, Sarhadi VK, Borze I, Karjalainen-Lindsberg ML, Sundstrom J, Ristamaki R, Osterlund P, Knuutila S (2012): MicroRNA profiling differentiates 
colorectal cancer according to KRAS status. Genes Chromosomes Cancer $\underline{51}$, $1-9$

Oberg AL, French AJ, Sarver AL, Subramanian S, Morlan BW, Riska SM, Borralho PM, Cunningham JM, Boardman LA, Wang L (2011): miRNA expression in colon polyps provides evidence for a multihit model of colon cancer. PLoS One $\underline{6}$, e20465

Pathak S, Meng WJ, Nandy SK, Ping J, Bisgin A, Helmfors L, Waldmann P, Sun XF (2015): Radiation and SN38 treatments modulate the expression of microRNAs, cytokines and chemokines in colon cancer cells in a p53-directed manner. Oncotarget $\underline{6}$, 44758-44780

Pfaffl MW (2001): A new mathematical model for relative quantification in realtime RT-PCR. Nucleic Acids Res $\underline{29}$, e45

Münter M, Weber KJ: Strahlenbiologie. In: Reiser M, Kuhn FP, Debus J (Hrsg.): Duale Reihe Radiologie. 3. Auflage; Thieme, Stuttgart 2001, 37-61

Ribeiro AO, Schoof CR, Izzotti A, Pereira LV, Vasques LR (2014): MicroRNAs: modulators of cell identity, and their applications in tissue engineering. Microrna $\underline{3}, 45-53$

(RKI/GEKID 2015:) Krebs in Deutschland 2011/2012. Häufigkeiten und Trends. 10. Ausgabe. Robert-Koch-Institut und die Gesellschaft der epidemiologischen Krebsregister in Deutschland e.V. (Hrsg.), Berlin 2015

Rothwell PM, Wilson M, Elwin CE, Norrving B, Algra A, Warlow CP, Meade TW (2010): Long-term effect of aspirin on colorectal cancer incidence and mortality: 20-year follow-up of five randomised trials. Lancet $\underline{376}, 1741-1750$ 
Salendo J, Spitzner M, Kramer F, Zhang X, Jo P, Wolff HA, Kitz J, Kaulfuss S, Beissbarth T, Dobbelstein M (2013): Identification of a microRNA expression signature for chemoradiosensitivity of colorectal cancer cells, involving miRNAs-320a, -224, -132 and let7g. Radiother Oncol 108, 451-457

Sauer R, Becker H, Hohenberger W, Rodel C, Wittekind C, Fietkau R, Martus P, Tschmelitsch J, Hager E, Hess CF (2004): Preoperative versus postoperative chemoradiotherapy for rectal cancer. N Engl J Med $\underline{351}, 1731$ 1740

Schetter AJ, Okayama H, Harris CC (2012): The role of microRNAs in colorectal cancer. Cancer J 18, 244-252

Schmoll HJ, Van Cutsem E, Stein A, Valentini V, Glimelius B, Haustermans K, Nordlinger B, van de Velde CJ, Balmana J, Regula J (2012): ESMO Consensus Guidelines for management of patients with colon and rectal cancer. A personalized approach to clinical decision making. Ann Oncol $\underline{23}$, 2479-2516

Schmiegel W, Pox C, Reinacher-Schick A, Adler G, Arnold D, Fleig W, Folsch UR, Fruhmorgen P, Graeven U, Heinemann V (2010): S3 guidelines for colorectal carcinoma: results of an evidence-based consensus conference on February 6/7, 2004 and June 8/9, 2007 (for the topics IV, VI and VII). Z Gastroenterol $\underline{48}, 65-136$

Slattery ML, Herrick JS, Pellatt DF, Mullany LE, Stevens JR, Wolff E, Hoffman MD, Wolff RK, Samowitz W (2016): Site-specific associations between miRNA expression and survival in colorectal cancer cases. Oncotarget $\underline{7}, 60193-$ 60205 
Spitzner M, Emons G, Kramer F, Gaedcke J, Rave-Frank M, Scharf JG, Burfeind P, Becker H, Beissbarth T, Ghadimi BM (2010): A gene expression signature for chemoradiosensitivity of colorectal cancer cells. Int J Radiat Oncol Biol Phys $\underline{78}$, 1184-1192

Su X, Liang $H$, Wang $H$, Chen G, Jiang $H$, Wu Q, Liu T, Liu Q, Yu T, Gu Y (2017): Over-expression of microRNA-1 causes arrhythmia by disturbing intracellular trafficking system. Sci Rep $\underline{7}, 46259$

Tischoff I, Tannapfel A (2012): Regression grading in gastrointestinal tumors. Pathologe $\underline{33}, 53-60$

Trakarnsanga A, Gonen M, Shia J, Nash GM, Temple LK, Guillem JG, Paty PB, Goodman KA, Wu A, Gollub M (2014): Comparison of tumor regression grade systems for locally advanced rectal cancer after multimodality treatment. J Natl Cancer Inst $\underline{106}, 10$

Wen J, Luo K, Liu H, Liu S, Lin G, Hu Y, Zhang X, Wang G, Chen Y, Chen Z (2016): MiRNA Expression Analysis of Pretreatment Biopsies Predicts the Pathological Response of Esophageal Squamous Cell Carcinomas to Neoadjuvant Chemoradiotherapy. Ann Surg 263, 942-948

Wittekind C, Meyer HJ: TNM Klassifikation maligner Tumoren. 7. Auflage. Wiley-VCH, Weinheim 2010

Yabushita S, Fukamachi K, Tanaka H, Sumida K, Deguchi Y, Sukata T, Kawamura S, Uwagawa S, Suzui M, Tsuda H (2012): Circulating microRNAs in serum of human $\mathrm{K}$-ras oncogene transgenic rats with pancreatic ductal adenocarcinomas. Pancreas $\underline{41}$, 1013-1018 
Yang L, Wei QM, Zhang XW, Sheng Q, Yan XT (2017): MiR-376a promotion of proliferation and metastases in ovarian cancer: Potential role as a biomarker. Life Sci $\underline{173}, 62-67$

Yau TO, Wu CW, Tang CM, Chen Y, Fang J, Dong Y, Liang Q, Ng SS, Chan FK, Sung JJ (2016): microRNA-20a in human faeces as a non-invasive biomarker for colorectal cancer. Oncotarget $\underline{7}, 1559-1568$

You W, Wang Y, Zheng J (2015): Plasma miR-127 and miR-218 might serve as potential biomarkers for cervical cancer. Reprod Sci 22, 1037-1041

Zhang C, Wang C, Chen X, Yang C, Li K, Wang J, Dai J, Hu Z, Zhou X, Chen $L$ (2010): Expression profile of microRNAs in serum: a fingerprint for esophageal squamous cell carcinoma. Clin Chem $\underline{56}, 1871-1879$

Zhou J, Lu S, Yang S, Chen H, Shi H, Miao M, Jiao B (2014): MicroRNA-127 post-transcriptionally downregulates Sept7 and suppresses cell growth in hepatocellular carcinoma cells. Cell Physiol Biochem $\underline{33}$, 1537-1546

\section{Internetquellen:}

Leitlinienprogramm Onkologie (Deutsche Krebsgesellschaft, Deutsche Krebshilfe, AWMF): S3-Leitlinie Kolorektales Karzinom, Kurzversion 2.0, 2017, AWMF Registrierungsnummer: 021/007OL, http://www.leitlinienprogrammonkologie.de/leitlinien/kolorektales-karzinom/ Zugriff am 13.01.2018

http://www.mirbase.org/cgi-bin/mirna_entry.pl?acc=MI0000472; Zugriff am 27.09.2017

http://www.mirbase.org/cgi-bin/mirna_entry.pl?acc=MI0000784; Zugriff am 27.09.2017 
http://www.mirbase.org/cgi-bin/mirna_entry.pl?acc=MI0000462; Zugriff am 28.09.2017

http://www.mirbase.org/cgi-bin/mirna_entry.pl?acc=MI0000651; Zugriff am 28.09.2017

\section{Veröffentlichung zum Thema}

September 2014 - Kurzvortrag und Erhalt Promotionspreis auf dem Viszeralmedizinkongress in Leipzig unter dem Titel:

Der Einfluss von miR-1, miR-127-3p, miR-376a und miR-152-3p auf das Ansprechen von Rektumkarzinomen auf eine neoadjuvante Radiochemotherapie 


\section{Danksagung}

Mein besonderer Dank gilt Herrn Prof. Dr. Jochen Gaedcke und Herrn Prof. Dr. B. Michael Ghadimi, die mir die Durchführung dieser Arbeit in Zusammenarbeit mit der klinischen Forschungsgruppe 179 ermöglicht haben. In diesem Zuge danke ich natürlich auch deren Mitgliedern Dr. Melanie Spitzner, Jessica Eggert und Chan Rong Lai. Die letzten ,Meter' einer solchen Arbeit sind oft sehr zäh und langwierig. In diesem Zusammenhang besonderer Dank an Frau Dr. Azadeh Azizian, die mir mit konstruktiver Kritik zur Seite stand.

Zudem bin ich Frau Dr. Julia Kitz und Herrn Dr. Peter Jo zu großem Dank hinsichtlich der Einarbeitung zum Anfärben und der Mikrodissektion der histologischen Schnitte verpflichtet. 